\title{
Organic matter processing and opportunities for stream mitigation in an intensively mined West Virginia watershed
}

\author{
Megan Stephanie Minter \\ West Virginia University
}

Follow this and additional works at: https://researchrepository.wvu.edu/etd

\section{Recommended Citation}

Minter, Megan Stephanie, "Organic matter processing and opportunities for stream mitigation in an intensively mined West Virginia watershed" (2009). Graduate Theses, Dissertations, and Problem Reports. 2822.

https://researchrepository.wvu.edu/etd/2822

This Thesis is protected by copyright and/or related rights. It has been brought to you by the The Research Repository @ WVU with permission from the rights-holder(s). You are free to use this Thesis in any way that is permitted by the copyright and related rights legislation that applies to your use. For other uses you must obtain permission from the rights-holder(s) directly, unless additional rights are indicated by a Creative Commons license in the record and/ or on the work itself. This Thesis has been accepted for inclusion in WVU Graduate Theses, Dissertations, and Problem Reports collection by an authorized administrator of The Research Repository @ WVU. For more information, please contact researchrepository@mail.wvu.edu. 
Organic matter processing and opportunities for stream mitigation in an intensively mined West Virginia watershed

Megan Stephanie Minter

\author{
A THESIS \\ Submitted to \\ The Davis College of Agriculture, Forestry, and Consumer Sciences \\ at \\ West Virginia University \\ in partial fulfillment of the requirements \\ for the degree of \\ Master of Science \\ In \\ Wildlife and Fisheries Resources
}

\title{
J. Todd Petty, Ph.D., Chair
}

Kyle J. Hartman, Ph.D.

J. Steven Kite, Ph.D.

Wildlife and Fisheries Resources Program

Division of Forestry

Morgantown, West Virginia

2009 


\section{ABSTRACT \\ Organic matter processing and opportunities for stream mitigation in an intensively mined West Virginia watershed}

Megan Stephanie Minter

Mountaintop removal /valley fill mining is a controversial process that may have far-reaching impacts on central Appalachian watersheds. Our project sought to quantify spatial and temporal variation in organic matter processing within Pigeon Creek, an intensively mined sub-watershed of the Tug Fork River in southern West Virginia. Our objectives were to: 1) quantify variation in organic matter retention and decomposition among streams differing in size (drainage area), gradient, and structural complexity; and 2) quantify the effect of valley fills on stream flow, water chemistry, organic matter processing, and benthic invertebrate colonization of detritus packs in $1^{\text {st }}$ order perennial streams. Our study area consisted of 26 sites distributed across a wide range of stream sizes (ephemeral channels to large perennial streams). Four of the small perennial sites were located below large valley fills and were paired to four undisturbed sites. At each site we quantified water temperature (continuous), stream flow (continuous), habitat quality and complexity, water chemistry (seasonal), artificial leaf and stick transport (seasonal), leaf pack decomposition (seasonal), and invertebrate colonization (seasonal). Organic matter decomposition rates were variable, but unrelated to any environmental factors that we measured. Drainage area, channel complexity, and mining had a significant interactive effect on transport distance of leaves and sticks. Sites below valley fills had enhanced flow levels, but this did not result in higher transport levels. Also, sites below valley fills had significantly higher conductivity, but this did not produce a significant effect on organic matter decomposition or on benthic invertebrate colonization of leaf packs. These results add to our understanding of complex interactive effects of mining on stream ecosystem functions and our ability to compensate for lost headwater functions through restoration actions downstream. 


\section{Table of Contents}

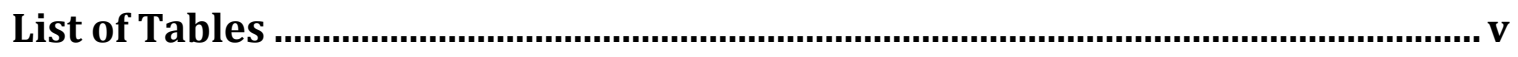

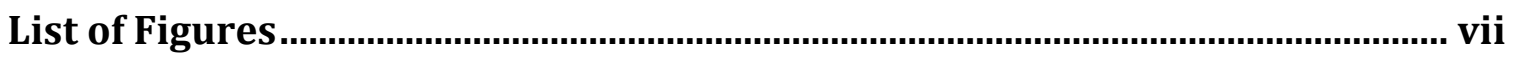

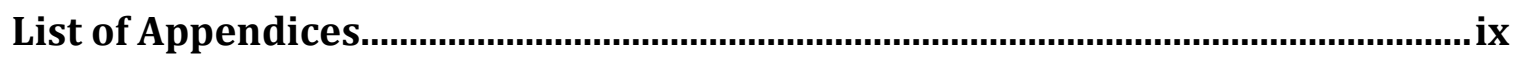

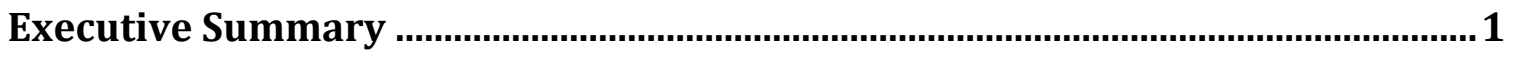

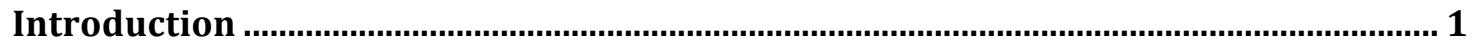

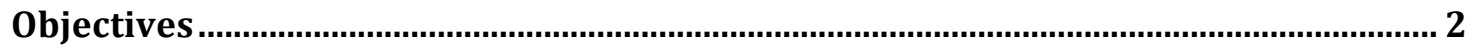

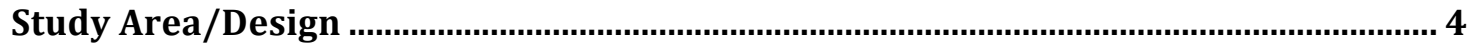

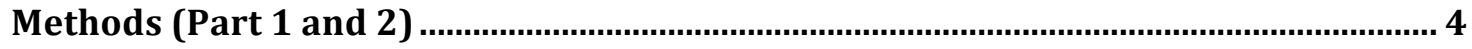

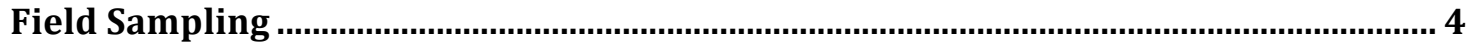

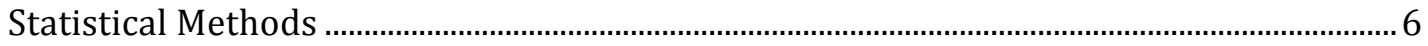

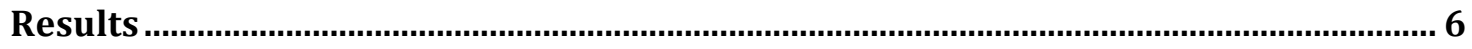

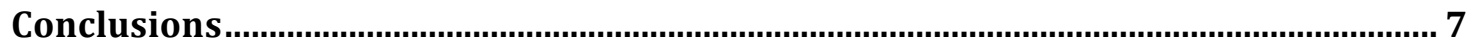

Organic Matter Processing in Streams Along a Drainage Area Continuum:

Towards a Functional Mitigation Currency in Mined Watershed ........................ 10

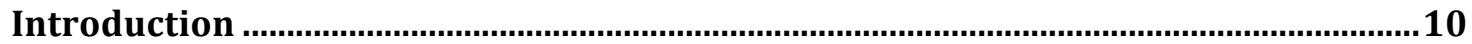

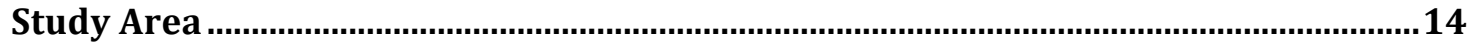

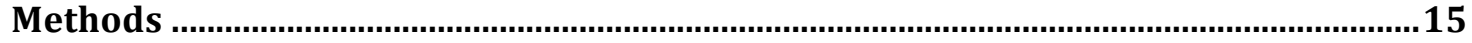

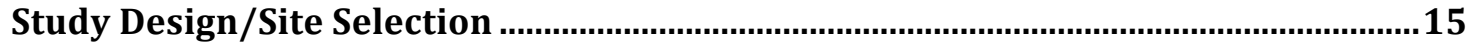

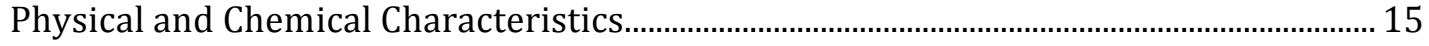

Organic matter retention, decomposition, and processing ability ......................................1 17

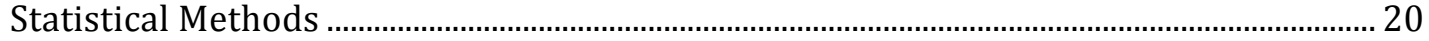

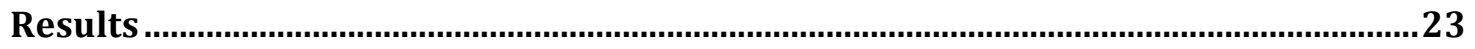

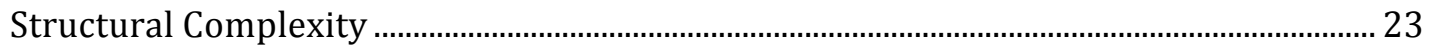

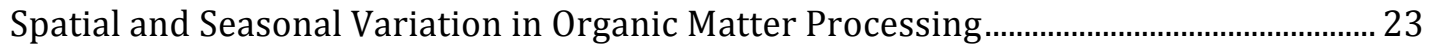

Organic Matter Processing and Structural Complexity ........................................................... 25

Discussion ................................................................................................................27

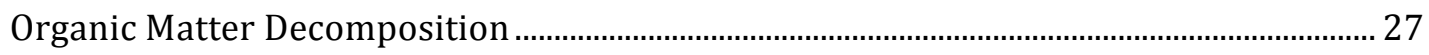

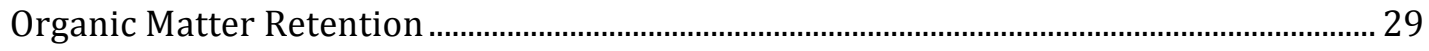

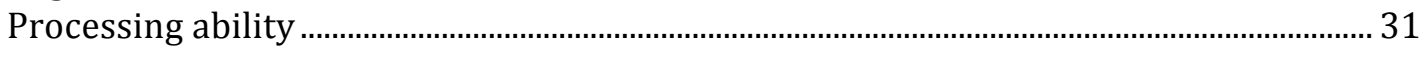

Stream flow, water chemistry, and organic matter processing downstream of

headwater valley fills in an intensively mined Appalachian watershed ...........68

Introduction ..................................................................................................................68

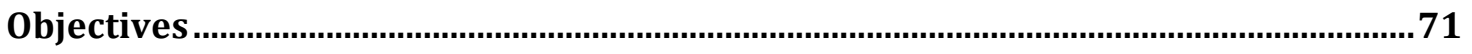

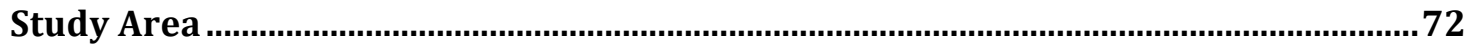

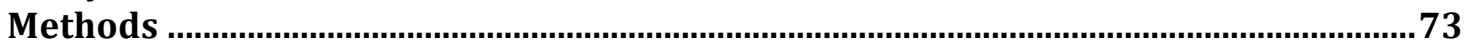

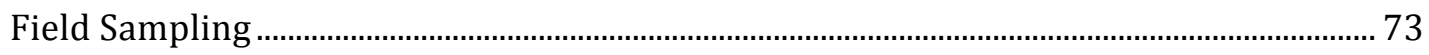

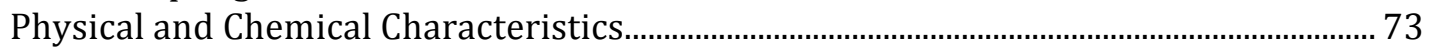

Organic matter retention, decomposition, and processing ability ……………………….. 75

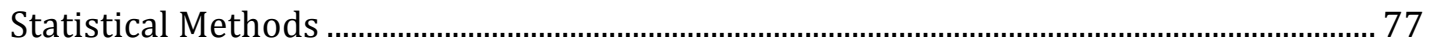

Results ......................................................................................................................79

Structural Complexity, Transport Distance and Decomposition............................................ 79

Comparisons Between Valley Fill and Control Sites ............................................................... 80 


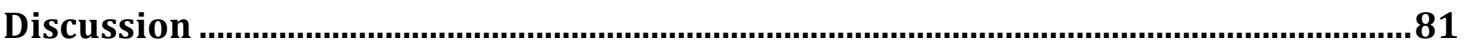

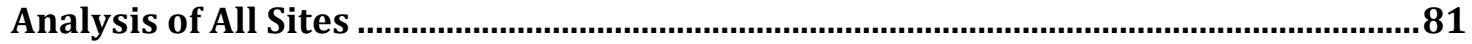

Differences Between Valley Fill and Control Sites................................................................ 81

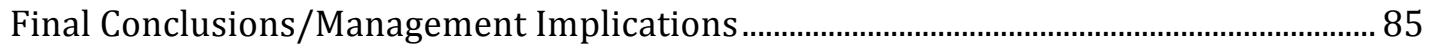




\section{List of Tables}

\section{Chapter 2}

Table 1: Dates for organic matter variables measured......................................................40

Table 2: Descriptive variables of all sites involved in the study .........................................41

Table 3: Principle components analysis results.....................................................................42

Table 4: Habitat variables and transport distances measured at each site ...................43

Table 5: Habitat variables across different basin area types (average (standard

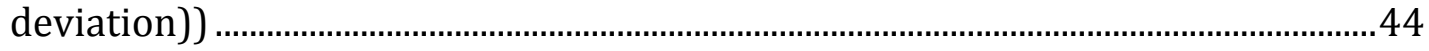

Table 6: Average transport distance for each basin area type. Values in parentheses represent standard error of the mean............................................................................4

Table 7: Average decomposition rates and processing ability for each stream type 46

Table 8: Average decomposition, water conductivity, and temperature for each site where leaf decomposition was measured. All temperatures are in degrees Celsius.

Table 9: Seasonal decomposition rates and processing ability for each site where decomposition was measured. ...........................................................................................4

Table 10: Correlations between average decomposition rate $\left(\mathrm{g}^{-1}\right)$ and water quality and macroinvertebrate data

Table 11: Correlations between structural complexity variables and average dowel transport distance. Correlation coefficient is listed first followed by the $\mathrm{p}$-value.

Table 12: Correlations between structural complexity variables and average leaf transport distance. Correlation coefficient is listed first followed by the $\mathrm{p}$-value.

Table 13: Multiple regression models for dowel transport distance................................52

Table 14: Multiple regression models for artificial leaf transport distance ..................53

Table 15: Multiple regression models for processing ability (PC 1 and conductivity

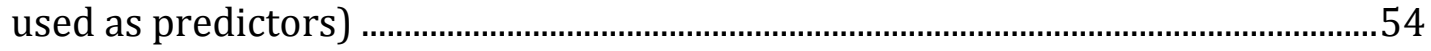

Table 16: Relative processing ability among all stream sizes (e.g. intermittent sites 
have $2 x$ lower processing ability than ephemeral sites and ephemeral sites have a range of processing ability values from 0.0003 to 0.0019 ). Values in parentheses represent the range of drainage areas covered by each stream type.

Table 17: Processing ability units (PAUs) as compared to ephemeral and intermittent channel average processing ability. A small perennial stream with low processing ability (PA) is $1 / 11^{\text {th }}$ that of the average ephemeral channel and for every 100 PAUs from an ephemeral cannel, there are 9 PAUs from a low PA small perennial stream. If a low PA stream can be restored to a high PA stream, 27 PAUs will be gained. .56

\section{Chapter 3}

Table 1: Descriptions of valley fill (VF) and control (C) sites .93

Table 2: Dates for organic matter variables measured.

Table 3: Principle components analysis results. A dot (.) means a variable is not included in a particular component.

Table 4: Correlations between structural complexity variables as predictors and dowel transport distance (meters/6 weeks) and artificial leaf transport distance (meters/30 mins). In these correlations, valley fill and control sites were grouped.

Table 5: Correlations between dowel transport distance (meters/ 6 weeks) and structural complexity variables for valley fill sites.

Table 6: Correlations between structural complexity variables and dowel transport distance (meters / 6 weeks) in control sites .................................................................98

Table 7: Decomposition and processing ability values for each site ................................99

Table 8: Results from t-tests between valley fill and control sites ................................ 100

Table 9: Water quality values for each site ……………………………............................... 101

Table 10: Two way ANOVA results for the effects of stream type (valley fill or control) and season on measured stream variables. Values shown are Fstatistics. 


\section{List of Figures}

\section{Chapter 2}

Figure 1: Distribution of mining throughout the watershed..............................................57

Figure 2: Parcel density in Upper Pigeon Creek.................................................................58

Figure 3: Range of temperature values across stream types. ...........................................59

Figure 4: Range of decomposition values across stream types........................................60

Figure 5: Relationship between seasonal dowel transport distance and drainage area

Figure 6: Distribution of Principle Component 1 scores (structural complexity measures) over grouped stream type. The higher the PC 1 score, the more

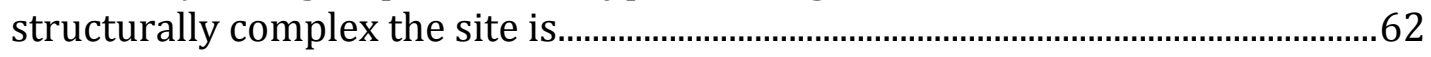

Figure 7: Processing ability in Fall 2007 for each group of stream types......................63

Figure 8: Processing ability in Spring 2008 for each group of stream types................64

Figure 9: Processing ability in Summer 2008 for each group of stream types............65

Figure 10: Principle Component 1 Score (complexity measures) and dowel transport

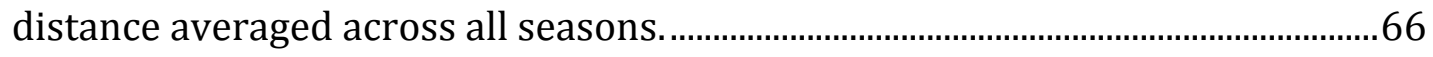

Figure 11: Principle Component 1 Score (complexity measures) and dowel transport distance averaged across all seasons. For Principle Component 1, the higher the score, the more complex the site is. There is a slight negative relationship between PC 1 and average dowel transport distance.

\section{Chapter 3}

Figure 1: Expectations of how valley fills affect decomposition and organic matter

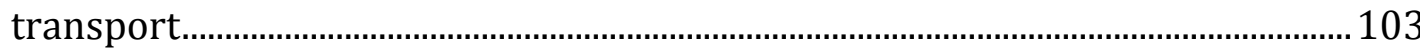

Figure 2: Range of decomposition values for valley fill and control sites separated by

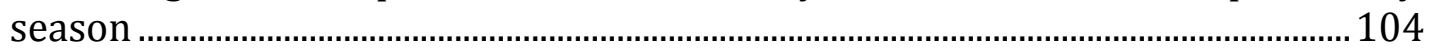

Figure 3: Average dowel transport distance for each season ........................................ 105

Figure 4: Rapid Visual Habitat Assessment Scores for each stream type .................... 106

Figure 5: Range of retentive scores for control and valley fill sites ..............................107

Figure 6: Range of values for the coefficient of variation of water level in control and 
valley fill sites. VF1 was not included in this graph................................................108

Figure 7: Seasonal CV water level without VF1..............................................................109

Figure 8: Seasonal processing ability for control and valley fill sites.............................110

Figure 9: NMDS plot of sites in 2 dimensional space. Macroinvertebrate data was used to create this plot. Sites with similar macroinvertebrate data from leaf

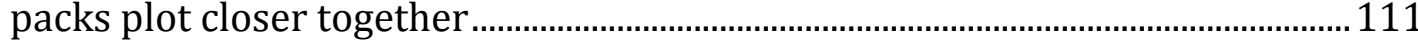

Figure 10: Average decomposition and conductivity ...................................................112 


\section{List of Appendices}

Appendix 1: Procedure developed and used to give each stream a retentive score........ 113 


\section{Executive Summary}

\section{Introduction}

Headwater streams are important to riverine ecosystem function, because they connect upland areas to larger streams and rivers. While highly variable in conditions, these streams provide important habitat for macroinvertebrates, plants, and small vertebrates. These streams are also tightly coupled to the land surrounding them (Gomi et al. 2002) and receive the bulk of the organic matter inputs in the watershed. They are very important for retaining and breaking down organic matter and this contributes nutrients to downstream ecosystems. Riparian, hydrologic, and substrate features all work in conjunction to retain organic matter. Headwaters have a high ratio of retentive features to stream width and retain much of the organic matter entering them (Brookshire and Dwire 2003).

Headwaters are often very vulnerable to land use impacts. One form of land use that can greatly affect these small streams is mountaintop removal (MTR) mining. This form of mining is common throughout southwestern West Virginia. It involves removing the overburden from layers of coal, extracting the coal, and replacing the overburden. However, not all overburden is placed back on the mountain. The leftover rock is placed into headwater valleys into what is called a “valley fill.” Valley fills permanently bury some headwater streams and remove their organic matter processing ability from the watershed. Valley fills also can have negative impacts on water quality (Hartman et al. 2005), macroinvertebrate 
communities (Merricks 2003; Pond et al. 2008), sedimentation (Wiley and Brogan 2003), and flow regime (Wiley et al. 2001; Phillips 2004).

Mountaintop removal mining has just begun to be studied and several questions are still to be answered: What are the functional losses related to organic matter processing experienced in impacted headwater streams? What is the extent to which organic matter processing varies spatially in mined watersheds? What is the opportunity for recovering lost organic matter processing through stream channel restoration in larger perennial streams? What, if any, direct impacts do valley fills have on the organic matter processing ability of headwater streams directly downstream?

\section{Objectives}

This study consisted of two different parts. Part one sought to quantify watershed scale variability in organic matter processing ability within an intensively mined region in southern WV. Part two examined the direct effects of MTR mining on organic matter processing in streams immediately downstream of valley fills.

Part 1: The overriding objective of part of the study was to quantify organic matter processing across a stream size gradient ranging from ephemeral to large perennial streams. To accomplish this objective we had four specific objectives: 1 . To quantify spatial and seasonal variation in organic matter retention and decomposition as a function of stream size, gradient, temperature, water quality, and structural complexity. 2. To quantify the overall organic matter processing ability lost on a per linear meter basis from headwater streams typically impacted by MTR mining. 3 . 
To determine if lost organic matter processing ability could be offset through stream channel restoration projects designed to increase channel complexity and physical retentiveness. 4. To calculate a mitigation ratio defined as the length of perennial stream restoration needed to offset functional losses per meter of disturbed headwater stream.

We hypothesized that organic matter processing rates would change across the stream size gradient. Larger streams with higher flow would be less retentive and therefore have lower processing rates. Higher gradient alone may cause a stream to be less retentive, but combined with the fact that most higher-gradient streams tend to be smaller and more structurally complex, many interacting factors probably exist. We further hypothesized that larger streams would have faster decomposition rates than smaller ones because they are wetter and mechanical breakdown would be greater.

Part 2: The overriding objective of this study was to quantify the effects of valley fills on organic matter processing, flow variability, and structural complexity in small perennial streams. To accomplish this objective we compared organic matter processing rates in streams immediately downstream of valley fills to those of control sites. Leaf decomposition rates were measured as well as instantaneous and long-term retention. Processing ability was also calculated using retention and decomposition data. Each site was also scored for its' biotic and abiotic retentiveness and habitat quality. Finally, flow and temperature variability were continuously monitored at each site. 


\section{Study Area/Design}

The study area was located on Pigeon Creek in Mingo County, West Virginia. Pigeon Creek is a tributary of the Tug Fork River and has an approximate basin area of $370 \mathrm{~km}^{2}$. This watershed has several interacting factors that have an impact on local conditions. The area is heavily mined; both surface mining and underground mining take place there. Also, the watershed is impacted by residential development. Development is most evident in the lower part of the watershed and mining is present in the headwaters.

For part one of the study, a total of 23 sites were selected to represent a range of basin areas and differing levels of impact around the watershed. The basin area covered in this study ranged from approximately $0.2 \mathrm{~km}^{2}$ to $165 \mathrm{~km}^{2}$ and includes ephemeral channels to large perennial sites.

For part two of the study, four small perennial stream sites were taken from part one and used as control sites. Four additional small perennial sites positioned below valley fills were selected. All eight sites were headwater reaches with basin areas ranging from $0.80-1.09 \mathrm{~km}^{2}$. All of the sites were similar in terms of channel width and basin area except for the association with a valley fill or not.

\section{Methods (Part 1 and 2)}

\section{Field Sampling}

Water quality, water temperature, and physical habitat characteristics were measured at each site. At sites included in part two of the study, water level was measured every ten minutes with monitors installed at each site (OnSet Corp). 
Habitat measurements included: Rapid Visual Habitat Assessment (RVHA) (Barbour et al. 1999), Bank Erosion Hazard Index (BEHI) (Rosgen 2001), thalweg profile (Petty 2001), and "retention scores." The "retention score" is a visual method for scoring a stream's structural retentiveness that we developed for this study (Appendix 1).

Organic matter retention was measured at each site for three different seasons and decomposition was measured at a subset of the part one sites for three seasons (Chapter 2: Table 2) (Lamberti 1996). Retention and decomposition were measured at all sites included in part two. Retention measurements included instantaneous and long-term retention. Instantaneous retention was measured with pieces of construction paper cut into small artificial leaves $(10 \mathrm{~cm}$ x $13 \mathrm{~cm})$. For long-term retention, fifty individually-numbered dowel rods were then released into the channel and allowed to remain for six weeks. Every other week, the distance each dowel had traveled was recorded. To measure decomposition, twelve leaf packs were placed in a riffle at each site and allowed to decompose for 75 and 120 days. Leaves were ashed and processed according to Benfield (1996).

Stream processing ability was also calculated as the product of organic matter retention and decomposition. Processing ability is a unit-less instantaneous rate that describes the ability of a stream reach to retain and decompose organic matter locally. Processing ability is important, because organic matter that is processed locally has a greater potential for being incorporated into the local food web, and it has a greater potential for subsidizing food webs downstream. 


\section{Statistical Methods}

For the statistical analysis in part 1 , stream types were grouped into three size-based groups: Ephemeral/Intermittent (6 sites), Small Perennial (8 sites), and Medium and Large Perennial sites (6 sites).

A combination of Principle components analysis (PCA), ANOVA and regression were used to analyze the data. PCA summarized and grouped habitat measurements. ANOVA determined any differences among drainage area types in terms of decomposition and retention. Two-way analysis of variance was used to determine effects of drainage area type and season on average transport distance and decomposition. Stepwise multiple regression with backward selection was used to create models for the prediction of average transport distance based on drainage area, gradient and structural complexity.

The statistical analysis in part 2 was similar to that in part 1 . T-tests were used to compare valley fill and control sites using decomposition rates, dowel transport distances, and water quality and habitat variables. Two-way ANVOA was used to determine the interacting effects of season and stream type (control or valley fill) on water level, temperature, water quality, organic matter transport and decomposition, and macroinvertebrate data.

\section{Results}

\section{Part 1:}

There was a significant positive relationship between basin area and overall transport distance and basin area was the best predictor of transport distance for each season. However, decomposition did not vary with basin area or any of the 
habitat variables. Stepwise multiple regression with backward selection results show that structural complexity was important for increasing organic matter retentiveness in small perennial streams, but not in large perennial or ephemeral / intermittent streams.

Because stream restoration in small and large perennial streams is often used as mitigation for impacts to ephemeral / intermittent streams, we calculated processing ability trading ratios for small and large perennial streams relative to ephemeral / intermittent streams. We found that for every 100 meters of ephemeral channel lost, 370 meters of heavily-impacted small perennial would need to be restored to regain lost processing ability (i.e., a 3.7 - to - 1 trading ratio).

\section{Part 2:}

Structural complexity was important for retention in the small headwater streams in part 2 . However, there was no significant difference between valley fill and control sites in terms of retention, decomposition, or habitat conditions. Although not statistically significant, water levels below valley fills tended to be more stable and higher than those of control sites.

\section{Conclusions}

On a drainage area scale, the best predictor of dowel and leaf transport distance was basin area. However, decomposition did not differ among basin areas. Water quality also did not vary among basin areas, which could help explain the lack of difference among decomposition values. Structural complexity and retention may be more of a force behind processing ability than decomposition rates. Our results indicate that structural complexity may play a role in processing ability in small 
perennial sites. However, small perennial sites are inherently highly variable and many interacting factors influence organic matter processing.

Our results also indicate that the streams that are lost or most impacted in MTR mining are also the ones that possess the highest processing ability. Off-site mitigation needs to focus on restoring small streams elsewhere in the watershed. According to our calculations with processing ability units, for every 100 meters of ephemeral channel lost approximately 370 meters of a degraded small perennial stream will need to be restored to begin to incorporate the lost processing ability of the ephemeral streams. Because we found that structural complexity did not influence processing ability in larger perennial streams, we do not believe that restoration in larger streams can be justified as mitigation for impacts to ephemeral / intermittent streams. Using the processing ability units, restoration efforts can be designed to make the most of mitigation where mitigation is possible.

In comparisons between valley fill and control sites, organic matter retention, decomposition rates, and processing ability did not differ between the sites. However, there seems to be an altered flow regime below valley fills: flows below valley fills were more stable than in control sites. Valley fills' sediment ponds and altered hydro-geology allow for flows to be more stable and higher than those of control sites. Higher flows may also be contributed to increased runoff due to less vegetation on valley fills. While these altered flows did not have a significant effect on dowel transport distances or decomposition, it is possible that flow interacts with other factors that cancel out the effects that flow alone would have on organic matter processing. With a detectable difference in flow, it is possible that there are 
other interacting, underlying factors impacting streams below valley fills. As in part 1 of the study, these small headwater streams are highly variable in condition and it's hard to tease apart effects of valley fills and land use from inherent variability of structural complexity in small perennial sites.

Small perennial sites turned out to be the focus in both parts of this study and also represented the most variability in the study. Structural complexity matters in these small streams and mitigation may be used to improve organic matter processing ability in a heavily-impacted watersheds. 


\section{Organic Matter Processing in Streams Along a Drainage Area Continuum: Towards a Functional Mitigation Currency in Mined Watershed}

\section{Introduction}

Small headwater streams play an important role in watershed ecology.

Although there are many definitions of a headwater stream, it is generally accepted that ephemeral, intermittent, and first order perennial streams make up a watershed's headwaters (Richardson and Danehy 2007). These streams connect the upland landscape to large rivers by retaining, processing, and exporting water, nutrients, and organic matter from upstream to downstream (Vannote et al. 1980). Headwaters are often overlooked because most contain very few, if any, permanent fish populations. However, up to $80 \%$ of the stream length in a watershed can be made up of headwater streams (Meyer 2001). These small streams break down leaves (Vannote et al. 1980; Webster et al. 1999), provide habitat for macroinvertebrates (Wallace et al. 1997; Wipfli 2005), and sometimes provide temporary refugia for small fishes (Wigington et al. 2006).

The headwaters of a stream form the beginning of a continuous pattern of transport, production, and utilization of material. Headwater streams are closely tied to the land surrounding them and receive large inputs of organic matter. These streams are very dependent on inputs of organic matter for productivity since many have a nearly complete canopy cover (Wallace et al. 1997; Richardson and Danehy 2007). They are very important for retaining and breaking down organic matter and this contributes nutrients to downstream ecosystems. Organic matter must be 
trapped within the stream in order for it to break down and supply nutrients to the ecosystem. Riparian, hydrologic, and substrate features all work in conjunction to retain coarse particulate organic matter (CPOM). Fisher et al. (1998) defined retention as the net amount of material removed from active transport. Headwaters are highly retentive, having a high ratio of retentive features to discharge (Brookshire and Dwire 2003). Retention is also highly dependent on stream morphology. CPOM retentiveness is increased with increasing channel roughness, and frequency of backwaters and lower velocity flow (Allan 1995). Therefore, streams are most retentive during low flow or baseflow, whereas most transport occurs during high runoff events.

Larger streams generally have lower retention than smaller ones (Wallace et al. 1982; Minshall et al. 1983; Naiman et al. 1987). Leaves and sticks are retained in pools and meanders, and on large woody debris, tree roots, boulders, and other items that add structural complexity to a stream channel. Streams that are more structurally complex may be better at retaining and breaking down organic matter than ones that are less complex. Studies have shown that streams with less large woody debris have lower retention (Jones and Smock 1991; Ehrman and Lamberti 1992; Webster et al. 1994). Smaller streams also tend to have more retention features than larger ones (Wallace et al. 1982). Differences in channel morphology are essential in creating leaf litter patches and in processing organic matter (Brookshire and Dwire 2003; Hoover et al. 2006).

Since many fishless headwaters are often overlooked, these streams can be vulnerable to impacts from land-use. One type of land use that greatly impacts 
headwaters is mountaintop removal mining (MTR mining) (Hartman et al. 2005; United States Environmental Protection Agency 2005; Pond et al. 2008). In this type of mining, overburden on top of coal layers is removed. After the coal is extracted, some of the overburden is replaced on site and some of it is placed into adjacent headwater valleys creating a valley-fill (Slonecker 2001). The ephemeral, intermittent, and sometimes small perennial streams in these valleys are permanently buried and can no longer contribute to the watershed's productivity. Hence, there exists a large need to mitigate for lost headwater function in surface mined watersheds. Since headwaters are such an integral part of the watershed, the loss of these streams can have far-reaching effects across an entire drainage.

MTR mining is especially common in southwestern West Virginia. This form of mining can have negative impacts on water quality (Hartman et al. 2005), macroinvertebrate communities (Merricks 2003; Pond et al. 2008), sedimentation (Wiley and Brogan 2003), and flow regime (Wiley et al. 2001; Phillips 2004). Pond et al. (2008) found that streams below valley fills are characterized by impaired macroinvertebrate communities. Baseflows in these streams can also be 6 to 7 times higher than in non-impacted sites (Wiley et al. 2001).

In addition, mountaintop removal mining in southern West Virginia is often coupled with considerable alteration of larger streams through residential development. Many larger streams in southern West Virginia watersheds are channelized and pinned against roadways. Dredging is also a common practice in this region following high flow events. The combination of disruption of the 
headwater catchment and the impacts downstream may have a large effect on organic matter processing.

Studies on the effects of MTR mining on watersheds leave several unanswered questions: What are the functional losses related to organic matter processing experienced in impacted headwater streams?; What is the extent to which organic matter processing varies spatially in a mined watershed?; and What is the opportunity of recovering lost organic matter processing function through stream channel restoration in larger perennial streams? Given these questions, the overriding objective of this study was to quantify organic matter processing across a stream size gradient ranging from ephemeral to large perennial streams within the upper Pigeon Creek watershed, an intensively mined watershed in southern WV. Specifically, we sought to: 1 . quantify spatial and seasonal variation in organic matter retention and decomposition as a function of stream size, gradient, temperature, water quality, and structural complexity; 2 . quantify the overall organic matter processing ability lost on a per linear meter basis from headwater streams typically impacted by MTR mining; 3. determine if lost organic matter processing ability could be offset through stream channel restoration projects designed to increase channel complexity and physical retentiveness; and 4. calculate a mitigation ratio defined as the length of perennial stream restoration needed to offset functional losses per meter of disturbed headwater stream.

We hypothesized that organic matter processing rates would change across the stream size gradient. Larger streams with higher flow would be less retentive and therefore have lower processing rates. Higher gradient alone may cause a 
stream to be less retentive, but combined with the fact that most higher-gradient streams tend to be smaller and more structurally complex, many interacting factors probably exist. We further hypothesized that larger streams would have faster decomposition rates than smaller ones because they are wetter and mechanical breakdown would be greater. We assumed that the mitigation ratio relating the length of perennial channel restoration needed to offset the lost functions per meter of headwater channel impact would exceed 1:1. However, we had no a priori expectation of how large a ratio would be required.

\section{Study Area}

Pigeon Creek is a subwatershed of the Tug Fork River in southern West Virginia. It has been affected by surface mining for decades and continues to be mined intensively (Figure 1). The watershed is also heavily impacted by residential development (Figure 2). At our largest site, the watershed covers approximately $165 \mathrm{~km}^{2}$. The entire Pigeon Creek subwatershed is approximately $320 \mathrm{~km}^{2}$. Major tributaries include Rockhouse Creek and Elk Creek. A total of 23 sites on 20 streams were included in this study. The basin areas above each site range from approximately $0.2 \mathrm{~km}^{2}$ to $165 \mathrm{~km}^{2}$ and included ephemeral channels to large perennial sites (Table 1). Since this area is both heavily mined and also impacted by development, there is a need for mining mitigation in the form of stream restoration. The area contains many potential opportunities for offsite mitigation to improve general conditions in the region. 


\section{Methods}

\section{Study Design/Site Selection}

The study consisted of 23 sites along a basin area continuum. The ArcGIS version 9.2 (ESRI 2006) was used to calculated drainage area (Strager et al. 2009). These sites were classified as follows:

E: ephemeral headwater: basin area: $0.16-0.18 \mathrm{~km}^{2} ; 3$ sites

I: intermittent headwater: basin area: $0.43-0.53 \mathrm{~km}^{2} ; 3$ sites

SP: small perennial headwater; basin area: 0.80-3.40 km²; 11 sites

MP: medium perennial; basin area: $10.1-31.9 \mathrm{~km}^{2} ; 3$ sites

LP: large perennial; basin area: 41.8-164.4 $\mathrm{km}^{2} ; 3$ sites

The guidelines in Fritz (2008) were followed when delineating headwater reaches and identifying ephemeral and intermittent streams. We included a large number of small perennial sites because we expected to observe a wide range of organic matter retentiveness in this size of stream. In addition, we believed that this size stream may provide some opportunity for increasing organic matter processing functions through stream channel restoration.

\section{Physical and Chemical Characteristics}

Water quality, water temperature, and physical habitat characteristics were measured at each site. Measurements of habitat and water quality help assess current conditions in the watershed and identify potential sites for restoration in the future. Since organic matter retention is linked to structural complexity (Brookshire and Dwire 2003), quantifying habitat offers a more complete picture of 
stream function. Conductivity $(\mu \mathrm{S} / \mathrm{cm})$ was measured as a surrogate of water quality in April 2007, November 2007, and April 2008. Pond (2004) found that conductivity was significantly correlated with the Kentucky Macroinvertebrate Bioassessment Index used to assess stream quality. A YSI 600 XL Multi-Parameter Water Quality Monitor (YSI Incorporated, Yellow Springs, $\mathrm{OH}$ ) was used to take these measurements in the field.

Habitat characteristics were measured at each site in Summer 2008. Measurements included: Rapid Visual Habitat Assessment (RVHA) (Barbour et al. 1999), Bank Erosion Hazard Index (BEHI) (Rosgen 2001), thalweg profile (Petty et al. 2001), and "retention scores." Temperature data was taken every hour at each site using continuous temperature loggers (OnSet Corp) from May 2008 to January 2009.

The thalweg profile is a habitat survey conducted along the thalweg of each site (Petty et al. 2001). It includes measures of depth, channel unit (riffle, run, pool, glide), distance to nearest fish cover, distance to nearest retentive feature, large woody debris count, pebble count (Wolman 1954), and gradient. Large woody debris were classified based on length and diameter (Petty et al. 2001). Fish cover was defined as any object within the active channel capable of concealing a $20-\mathrm{cm}$ fish. A retentive feature was any physical feature of the stream capable of retaining organic matter at the high water mark. Gradient was measured to the nearest $0.1 \%$ using a clinometer. Study reach lengths were set at $40 \mathrm{x}$ mean stream width (MSW), and points along the thalweg were spaced every $1 / 2 \mathrm{MSW}$ for streams wider than $5 \mathrm{~m}$ and every 1 MSW for streams narrower than $5 \mathrm{~m}$ (Petty et al. 2001). 
The "retention score" is a visual method for scoring a stream's structural retentiveness that we developed for this study (Appendix 1). It scores like an extra category for the RVHA protocol. Retentiveness is based on two separate parts of a stream's structure: abiotic retentiveness and biotic retentiveness. Abiotic retentiveness refers to a stream's ability to retain organic matter with abiotic features. Biotic retentiveness refers to a stream's ability to retain organic matter with biotic features. After walking the entire stream reach, a stream is scored based on how well it will retain organic matter (small sticks and leaves). Scores are based on what would be ideal for that particular basin area. For example, a small headwater stream will be inherently more retentive than a $3^{\text {rd }}$ or $4^{\text {th }}$ order stream. The larger stream doesn't score lower than the headwater stream just based on size alone. If both streams were optimal for their size, they both would receive the same score. For the purpose of this habitat assessment, a stream is scored based on its inorganic retentiveness and its organic retentiveness. Abiotic retentive features include: boulders, undercut banks, a natural meander pattern, and side pools. Organic retentive features include: large woody debris (LWD), root wads, and overhanging limbs.

\section{Organic matter retention, decomposition, and processing ability}

Organic matter retention was measured at each site for three different seasons and decomposition was measured at a subset of the sites for three seasons (Table 2) (Lamberti 1996). These measurements help quantify how a mined watershed processes organic matter and how this process varies spatially and seasonally. Retention included instantaneous and long-term retention. 
Instantaneous retention was measured with pieces of construction paper cut into small artificial leaves $(10 \mathrm{~cm} \times 13 \mathrm{~cm})$. Artificial leaves were released at the top of a reach and allowed to float downstream for approximately 30 minutes. After all transport had stopped, the distance each leaf had traveled was measured and the object on which it was retained was recorded. For any leaf that exited the reach, the reach length was recorded as the distance traveled. Reach length was set at $10 \mathrm{x}$ wetted width. For long-term retention, fifty individually-numbered dowel rods were then released into the channel at the upstream end of the same reach. The dowels were uniform size and shape: $18 \mathrm{~cm}$ long and $0.5 \mathrm{~cm}$ diameter. The dowels were spread uniformly across the channel all at once and allowed to float downstream. After 30 minutes the distance each dowel had traveled and what it was retained on was recorded. For dowels that exited the reach, the reach length was recorded as the distance traveled. The dowels were left in the channel for six weeks and every two weeks the distance traveled was recorded.

Using this data, the seasonal retention rate was calculated for each site. The retention rate is expressed as (Speaker 1984):

$$
T_{d}=T_{o} e^{-k d}
$$

$T_{d}$ is the percent of dowels that exited the reach at the end of the study period. $T_{o}$ is $100 \%$. The instantaneous retention rate is represented by $\mathrm{k}$. The reach length (here, 10x wetted width) is represented by $\mathrm{d}$.

Organic matter breakdown was also measured at 16 of the sites (Benfield 1996). The sites selected for organic matter breakdown represented the entire range of basin areas included in the study $\left(0.2 \mathrm{~km}^{2}\right.$ to $\left.165 \mathrm{~km}^{2}\right)$. Twelve leaf packs 
were placed in a riffle at each site and allowed to decompose for 75 and 120 days. The leaf packs consisted of 10 grams of pin oak leaves each in $1 \mathrm{~cm}$ mesh bags. The packs were secured with rope either to roots or rebar hammered into the streambed. Six packs were removed after 75 days and the remaining six were removed after 120 days. After removal, the packs were kept on ice for transport back to the lab. Once in the lab, leaves were rinsed of sediment over a $250 \mu \mathrm{m}$ sieve to preserve any macroinvertebrates. The macroinvertebrates were stored in $95 \%$ ethanol for later identification to genus level and functional feeding group (Merritt et al. 2008). After rinsing, the leaves from each site were placed in brown paper bags and allowed to air dry at room temperature for several days. Once dry, the leaves were crushed into a coarse powder. A muffle furnace was used to combust $250 \mathrm{mg}$ of the coarse powder from each site for 40 minutes (Benfield 1996). Ashfree dry mass (AFDM) was calculated using the following formula:

\%Organic Matter $=\left(\mathrm{DM}_{\text {sample }}-\mathrm{AM}_{\text {sample }}\right) / \mathrm{DM}_{\text {sample }} \mathrm{x} 100$ $\mathrm{AFDM}=\mathrm{DM} \times \mathrm{\% OM}$ \%AFDM remaining= 100-((initial-final)/initial x 100) (DM= dry mass; $\mathrm{AM}=$ ash mass; $\mathrm{OM}=$ Organic Matter)

\%AFDM remaining was then log-transformed and regressed against the days of exposure. The slope of the line is the K-value, or rate of decomposition (Benfield 1996).

Stream processing ability was also calculated based on organic matter retention and decomposition. Processing ability is defined as the relative ability of a 
stream to retain and process organic matter locally. It is a way to quantify how well a site can retain and subsequently break down organic matter entering into it. The organic matter is incorporated into the local food web or is delivered downstream. To calculate each stream's season-specific processing ability, we multiplied the seasonal decomposition rate by the seasonal retention rate.

After processing ability was calculated, processing ability units (PAUs) were calculated to create a trading ratio that may be used for mitigation projects. The average processing ability of ephemeral channels was used as a baseline for the calculation. If ephemeral channels have a relative processing ability of 1 , a heavily impacted small perennial channel will have a processing ability that is a fraction of the baseline ephemeral processing ability. A structurally complex small perennial channel will also have a fraction of the processing ability of an ephemeral channel, but it should have a larger fraction than that of a heavily impacted small perennial. Processing ability trading ratios were then calculated for perennial streams. The trading ratios could be defined as the length of perennial stream (in meters) that would need to be restored in order to replace the functional loss (in terms of organic matter processing ability) from $1 \mathrm{~m}$ of ephemeral or perennial channel impacted by mining.

\section{Statistical Methods}

Leaf and dowel rod transport distances were calculated for each site and each season. Averages across all seasons for each site were also calculated. Unless otherwise noted, "average transport" refers to transport distance averaged across 
all seasons. Decomposition rate was also calculated for each of three seasons. The average decomposition for all three seasons was used in much of the analysis.

Variation in depth and temperature were used as indices for sites. Using the depth data from the thalweg profile, a coefficient of variation of depth at the thalweg for each site was calculated. This coefficient of variation of depth was used as another structural complexity variable. Because many of the ephemeral and intermittent sites were dry, the coefficient of variation of depth was not used for these sites. Using the temperature data, a coefficient of variation of temperature, average minimum, average maximum, average temperature, average daily range, maximum daily range, average daily coefficient of variation, and maximum daily coefficient of variation was calculated for each site.

For most statistical analyses, stream types were grouped into three sizebased groups: Ephemeral/Intermittent (6 sites), Small Perennial (8 sites), and Medium and Large Perennial sites (6 sites). Also, the variables "average gradient", "canopy cover" and "large woody debris per meter" were log-transformed to homogenize variance and meet normality assumptions for parametric statistics.

Simple correlation among predictor variables was used to identify redundant and covarying variables. Highly redundant variables (i.e., correlation coefficient > 0.9) were deleted from further analyses. Principle Components Analysis (PCA) was then used to summarize the following co-varying habitat measures: retentive score, number of retentive features per meter, large woody debris per meter, RVHA score, canopy cover, coefficient of variation of depth, and mean distance (meters) to retentive feature. To facilitate interpretation, the PCA results were then correlated 
with all of the structural complexity variables. Correlation analysis was used to determine the relationship between basin area and transport distance and decomposition. Two-way analysis of variance $(\alpha=0.05)$ was used to test for effects of drainage area type (ephemeral, intermittent, small perennial, medium perennial, and large perennial) and season (Fall 2007, Spring 2008, Summer 2008) on average transport distance and decomposition. Average transport distance for both dowels and leaves and average decomposition rate were used as the response variables; drainage area type, season, and their interaction were used as factors in the ANOVA. Using macroinvertebrate data collected from leaf packs, percent shredders, percent collector-gatherers, percent predators, and percent other were calculated. These variables were correlated with decomposition data to determine any relationship between decomposition rates and macroinvertebrates. ANOVA was used to compare macroinvertebrate data across basin area types.

Stepwise multiple regression with backward selection was used to create models for the prediction of average transport distance based on drainage area, gradient and structural complexity. An alpha value of 0.25 was used to determine variable entry into the model, and an alpha value of 0.10 was used to determine overall model acceptance. Also, pairwise correlations were run between transport distances averaged across all seasons and the following structural complexity variables: large woody debris per meter, mean distance to retentive feature, retentive score, RVHA score, PC 1, number of retentive features per meter, and coefficient of variation of depth. Finally, stepwise multiple regression with 
backward selection was used to create models for the prediction of processing ability based on conductivity and structural complexity.

\section{Results}

\section{Structural Complexity}

PCA grouped structural complexity measures into 2 significant axes (Table 3). PC 1 included measures of: retentive score, number of retentive features per meter, large woody debris per meter, RVHA score, coefficient of variation of depth, and mean distance (meters) to retentive feature. PC 2 included coefficient of variation of depth and RVHA score. Only principle component 1 was interpreted. Principle Component 1 was negatively related to basin area (correlation=-0.6292, d.f. $=22$, p-value $=0.0013$ ).

\section{Spatial and Seasonal Variation in Organic Matter Processing}

The sites exhibited a wide range of habitat, organic matter processing, and water quality conditions (Tables 4-9; Figures 3 and 4). Table 4 shows site-by-site results from habitat surveys as well as leaf and dowel transport distances. All of our ephemeral and intermittent sites had relatively high retentive scores and medium and large perennial sites had much lower scores. Small perennial sites had the most variation in retentive score. Averages and standard errors for habitat and water quality variables for each basin area type are presented in Table 5. Figure 3 visually shows the range of average temperature $\left({ }^{\circ} \mathrm{C}\right)$ values recorded for each basin area group. Again, small perennial sites had the most variation. Tables 6 and 7 show averages and standard errors for transport distances, decomposition, and 
processing ability. The average range of decomposition values are displayed in Figure 4. Decomposition values varied among all basin area types, but all values were in the range of $0.0030-0.0060 \mathrm{~g}^{-1}$ as shown in Tables 8 and 9.

There was a significant positive relationship between basin area and overall transport distance (correlation $=0.9376$, d.f. $=22$, $p$-value $<0.0001$ ) (Figure 5). Figure 5 shows an exponential increase in transport distance with basin area. There was no significant relationship between decomposition and basin area (correlation= 0.0831, d.f. $=11$, $p$-value $=0.7973$ ). There was no interaction between season and stream type (Prob $>\mathrm{F}=0.6478$ ) for decomposition. However, season had a significant effect on decomposition $\left(R^{2}=0.7842\right.$, Prob $\left.>F=<0.0380\right)$; Summer 2008 was significantly different from both Fall 07 and Spring $08(\mathrm{Q}=2.48)$ in terms of decomposition.

Decomposition was also not related to any of the habitat variables or conductivity (correlation $=-0.0710$, d.f. $=11$, $\mathrm{p}$-value $=0.8265$ ). Decomposition was not significantly related to $\%$ collector gatherers, $\%$ predators, $\%$ shredders, or $\%$ other. There were no strong correlations between average decomposition rate and water quality and macroinvertebrate data (Table 10). Nor was there a single good predictor of decomposition in this watershed (Table 10).

Temperature results also show the same pattern. Average temperature was not significantly different across drainage area (DA) type (Prob $>F=0.2036$ ). Coefficient of variation of temperature (CV Temp) was not significantly different across DA type (Prob $>F=0.9953)$. Mean daily range of temp was not significantly 
different across type (Prob $>\mathrm{F}=0.3470$ ). Macroinvertebrate abundances were not significantly different across basin area types except for $\%$ other (Prob $>\mathrm{F}=0.0253$ ).

\section{Organic Matter Processing and Structural Complexity}

The sites exhibited a wide range of habitat conditions. Small perennial sites had the most variation in habitat among all drainage area types. Basin area was the best predictor of transport distance for each season (Figure 5). Transport distance increased exponentially with basin area as shown in Figure 5. Figure 6 shows the range of PC1 scores across basin area types. For medium and large perennial sites, the retentive score was positively correlated with dowel transport distance (correlation $=0.9151$, d.f. $=5, p$-value $=0.0105$ ) and artificial leaf transport distance (correlation $=0.9522$, d.f. $=5$, $p$-value $=0.0034)($ Tables 11 and 12). PC 1 was also positively correlated with average dowel transport distance and artificial leaf transport distance in medium and large perennial sites.

For small perennial sites, average dowel transport distance was slightly correlated with several habitat variables. Unlike larger sites, for small perennial sites, transport distance was negatively correlated with habitat variables. In the strongest relationship, average dowel transport distance was negatively correlated with retentive score (correlation $=-0.5760$, d.f. $=10, p$-value $=0.0246$ ). Ephemeral/intermittent sites also had correlations with habitat variables. Dowel transport distance was slightly related to coefficient of variation of depth (correlation $=0.5399$, d.f $=5, p=0.2689$ ).

Stepwise multiple regression with backward selection results show that structural complexity is important for organic matter transport in small perennial 
sites. Presented in tables 13 and 14, PC 1 was important in the model for small perennial sites. This model was the only significant model.

The best predictor of processing ability was conductivity for all seasons (Table 15). Table 15 shows results from multiple regression models for processing ability in each season. For Fall 2007, Principle Component 1 was also included in the model. Ephemeral sites had the highest values for processing ability (Table 16; Figures 7-9). Large perennial sites had the lowest processing ability. Small perennial sites had the widest range of processing ability as shown in Figures 7-9. Table 16 shows relative processing ability for each stream type compared to ephemeral streams. Ephemeral sites had 653 times higher average processing ability than large perennial sites. In general, as basin area increases, processing ability decreases.

Processing ability trading ratios were created for small perennial streams compared to ephemeral and intermittent streams (Table 17). The average processing ability for an ephemeral stream is 0.0011 . The lowest average processing ability for a small perennial is 0.0001 and the highest is 0.0004 . Using the data for processing ability and PAUs, we calculated that for every 1 meter of ephemeral channel lost, 3.7 meters of heavily-impacted small perennial stream would need to be restored to regain lost processing ability. In other words, a trading ratio of 3 or 4:1 is needed to offset functional losses. We also calculated that for every 1 meter of intermittent channel lost, 1.67 meters of impacted small perennial stream would need to be restored. 


\section{Discussion}

\section{Organic Matter Decomposition}

There was no direct effect of drainage area on organic matter decomposition in this watershed, however ephemeral and intermittent sites had the widest range of decomposition rates (Figure 4). These small streams were highly variable in their contribution to the processing ability of the watershed. The differences we observed, however, were not related to any of the measured co-variables, including drainage area, gradient, temperature, conductivity, and benthic macroinvertebrate community structure. This could be because of the natural variability of organic matter processing or the natural variability of small streams. Sponseller and Benfield (2001) found that, at the watershed scale, decomposition was not significantly related to land cover. Our results also support this finding.

Temperature and conductivity also did not significantly differ across drainage area, and this could help explain the lack of a significant difference in decomposition rate across drainage area. Also, our "organic matter" was secured into place with rope and rebar. In larger sites, most of the natural organic matter would be flushed out because of higher flows and less structural complexity. Benfield et al. (2000) suggests that downstream locations naturally have fewer resources and therefore leaf packs may attract macroinvertebrates, artificially elevating the decomposition rate. Our values for large streams may only represent potential decomposition. In these large sites, it is very likely that most of the leaves would have been washed downstream. Since our leaves were secured in place, the 
decomposition rate could have been higher than if the leaves had been allowed to be transported downstream.

Leaf breakdown is influenced by many complex, interacting factors including nutrients, temperature, wetness, stream flow and macroinvertebrates (Webster and Benfield 1986). First, leaching involves the loss of $10-25 \%$ of the initial nitrogen content. Second, colonization of the leaf by fungi and bacteria occurs. This colonization conditions the leaf for the third step, which is mechanical breakdown by the stream current and abrasion and macroinvertebrates. Some studies show that leaves break down faster in riffles (Cummins et al. 1980) and some studies show that leaves break down faster in pools (Kobayashi and Kagaya 2005; Hoover et al. 2006). We did not compare between the two channel reach types and this may be something to include in future studies. Pools in headwater channels may decompose differently than pools in larger streams.

Many of our larger sites are also impacted by residential development and nutrient input. Nutrient enrichment should normally accelerate leaf breakdown (Gulis and Suberkropp 2003; Paul 2006). However, other pollutants entering the system may have the opposite effect on breakdown rates. For example, slower breakdown rates may be expected at the pollution source because of low dissolved oxygen but higher rates may be expected downstream because of nutrient increases (Webster and Benfield 1986; Hagen et al. 2006). We did not test for the effects of elevated nutrient levels on decomposition for this study. If low dissolved oxygen decelerated decomposition in our larger sites, this could help explain why our decomposition rates did not differ among basin area types. Simon et al. (2009) 
found that leaf breakdown was slowed with decreasing $\mathrm{pH}$ and decreasing water quality. Perhaps our expectation of higher decomposition at larger sites was offset by the poorer water quality at these sites.

Hagen et al. (2006) and Bird and Kaushik (1992) found that leaf breakdown rates were not a good indicator of stream health across a land-use gradient. Many interacting factors affected decomposition: nutrient concentration, temperature, sedimentation, dissolved oxygen and physical abrasion. Our sites represent a similar gradient from headwaters to mainstem sites. Our headwater sites, though affected by mining, are generally less affected by human activity than larger sites. Perhaps along our gradient as well, decomposition is not a very good indicator of ecosystem health. Since decomposition did not differ significantly across basin area types in relation to any of our measured parameters, structural complexity and retention may be more of a driving force behind processing ability in this watershed. Consequently restoration and protection actions should be focused on maximizing the overall retentiveness of the watershed.

\section{Organic Matter Retention}

As expected, retention was strongly influenced by drainage area, and structural complexity increased OM retention in small streams. This is consistent with the view that stream flow and the coarseness of the stream bed influence the rate at which detritus and other materials are transported from the stream channel. Contrary to expectations, however, OM retention in larger streams declined with increasing structural complexity. Sample sizes were admittedly low in larger streams. Nevertheless, the patterns observed were very consistent; suggesting that 
complexity in larger streams increases the rate of material transport. The most likely explanation for this result is that structural features that increase bed complexity in larger streams also act to focus stream flows towards the thalweg and this results in increased material transport. Those same structural features in smaller streams act to "grab" materials, thereby increasing retentiveness. Regardless of the underlying mechanisms, these results suggest that stream restoration actions directed towards larger streams would do little to offset functional losses to small streams. Consequently, mitigation of impacts to headwater streams will need to be addressed through restoration actions implemented on small perennial streams. Headwaters are highly retentive naturally; they have a high ratio of retentive features to discharge (Brookshire and Dwire 2003). These small streams are also very often dominated by small wood (Latterell 2006). Large wood adds structural complexity to streams, and in smaller streams this can increase retention (Ehrman and Lamberti 1992). Our medium and large perennial sites had very little large woody debris and most structural complexity came from channel meanders and boulders. Structural complexity, presence of large wood, and riparian vegetation are important factors in organic matter retention (Brookshire and Dwire 2003). Hoover et al. (2006) found that, in second-order streams, channel features that influenced structural complexity were most important in retention. Small streams are also highly variable in structure and their ability to retain organic matter (Riis 2006). In most of the habitat variables we sampled for, our small perennial sites had the most variation. This, along with our results that structural complexity increases retention in small streams suggest that 
the most retention can be gained from restoration projects in small streams rather than larger ones. The retentive score developed for this study can be used as an important factor when considering mitigation projects. When used as part of the Rapid Visual Habitat Assessment, it offers a quick and easy way to identify potential mitigation sites.

\section{Processing ability}

Small streams possessed the highest OM processing ability in the watershed and this is consistent with previous studies (Vannote et al. 1980; Minshall et al. 1983;

Naiman et al. 1987). We found that the processing ability of ephemeral streams was 653 times higher than large perennial sites. Processing ability and habitat conditions were most variable in small perennial sites, allowing the most room and potential for restoration. These sites had just 4 times lower processing ability than ephemeral sites and 1.67 times lower processing ability than intermittent streams. The loss of the processing ability of ephemeral and intermittent sites may be not able to be recovered entirely but restoration in small perennial sites will regain a portion of the lost function. Consequently, the potential exists for increasing organic matter processing through restoration of highly degraded small perennial streams. Lepori et al. (2005) found that channelization in forest streams decreased leaf retention and increased mechanical fragmentation of leaves. The study also determined that this could be reversed through channel restoration activities such as the placement of boulders. The placement of wood and wood structures has also been demonstrated to increase retentiveness of dowels (Millington and Sear 2007). However our results indicate that restoration efforts in large streams would not be 
useful in recovering organic matter processing function. Processing ability in larger streams is so much less than that of ephemeral and intermittent streams that it is not practical for restoration projects in these streams to be used as off-site mitigation.

Using the processing ability units, restoration efforts can be guided to make the most of mitigation. Our results indicate that for every 1 meter of ephemeral channel lost approximately 3.7 meters of a degraded small perennial stream will need to be restored to begin to incorporate the lost processing ability of the ephemeral site, giving a trading ratio of 3 or $4: 1$. Intermittent sites have a trading ratio of approximately $2: 1$. The ratio will only work in areas where streams are impacted by more than just mining. A perfectly restored small perennial site can never become equal to an ephemeral site. Areas with largely unimpacted small perennial sites will not be able to benefit from such off-site mitigation. 
Works Cited

Allan, J. D. 1995. Stream ecology, 1st edition. Chapman and Hill, Philadelphia.

Barbour, M. T., J. Gerritsen, B. D. Snyder, and J. B. Stribling. 1999. Rapid bioassessment protocols for use in streams and wadeable rivers: Periphyton, benthic macroinvertebrates and fish, second edition. Epa 841-b-99-002. U.S. Environmental Protection Agency; Office of Water; Washington, D.C.

Barnden, A. R., and J. S. Harding. 2005. Shredders and leaf breakdown in streams polluted by coal mining in the south island, new zealand. New Zealand Natural Sciences 30:35-48.

Benfield, E. F. 1996. Leaf breakdown in stream ecosystems. Pages 579-590 in F. R. Hauer, and G. A. Lamberti, editors. Methods in stream ecology. Academic Press, New York.

Benfield, E. F., J. R. Webster, J. J. Hutchens, J. L. Tank, and P. A. Turner. 2000. Organic matter dynamics along a stream-order and elevational gradient in a southern appalachian stream. Verhandlungen der Internationalen Vereinigung für theoretische und angewandte Limnologie 27:1341-1345.

Bird, G. A., and N. K. Kaushik. 1992. Invertebrate colonization and processing of maple leaf litter in a forested and an agricultural reach of a stream. Hydrobiologia 234(2):65-77.

Braioni, M. G., M. D. Cortivo, and G. Salmoiraghi. 2004. Leaf litter breakdown processing in the functional monitoring of a mountain stream. International Review of Hydrobiology 89(5-6):536-550.

Brookshire, E. N. J., and K. A. Dwire. 2003. Controls on patterns of coarse organic particle retention in headwater streams. Journal of the North American Benthological Society 22(1):17-34.

Carpenter, J., W. E. Odum, and A. Mills. 1983. Leaf litter decomposition in a reservoir affected by acid mine drainage. Oikos 41(2):165-172.

Clarke, K. R. 1993. Non-parametric multivariate analyses of changes in community structure. Austral Ecology 18(1):117-143.

Cummins, K. W., and coauthors. 1980. Processing of confined and naturally entrained leaf litter in a woodland stream ecosystem. Limnology and Oceanography 25(5):952-957.

Dalzell, B. J., T. R. Filley, and J. M. Harbor. 2007. The role of hydrology in annual organic carbon loads and terrestrial organic matter export from a 
midwestern agricultural watershed. Geochimica et Cosmochimica Acta 71(6):1448-1462.

Dangles, O., M. O. Gessner, F. Guerold, and E. Chauvet. 2004. Impacts of stream acidification on litter breakdown: Implications for assessing ecosystem functioning. Journal of Applied Ecology 41(2):365-378.

Ehrman, T. P., and G. A. Lamberti. 1992. Hydraulic and particulate matter retention in a 3rd-order indiana stream. Journal of the North American Benthological Society 11(4):341-349.

ESRI. 2006. Arcgis version 9.2 and the spatial analyst extension. Environmental Systems Research Institute, Redlands, CA.

Fisher, S. G., N. B. Grimm, E. Martí, R. M. Holmes, and J. J. B. Jones. 1998. Material spiraling in stream corridors: A telescoping ecosystem model. Ecosystems 1(1):19-34.

Fritz, K. M., Johnson, Brent R., Walters, David M. 2008. Physical indicators of hydrologic permanence in forested headwater stream. Journal of the North American Benthological Society 27(3):690-704.

Gessner, M. O., E. Chauvet, and M. Dobson. 1999. A perspective on leaf litter breakdown in streams. Oikos 85(2):377-384.

Gomi, T., R. C. Sidle, and J. S. Richardson. 2002. Understanding processes and downstream linkages of headwater systems. BioScience 52:905-916.

Greenwood, J. L., and A. D. Rosemond. 2005. Periphyton response to long-term nutrient enrichment in a shaded headwater stream. Canadian Journal of Fisheries \& Aquatic Sciences 62(9):2033-2045.

Gulis, V., and K. Suberkropp. 2003. Leaf litter decomposition and microbial activity in nutrient-enriched and unaltered reaches of a headwater stream. Freshwater Biology 48(1):123-134.

Hagen, E. M., J. R. Webster, and E. F. Benfield. 2006. Are leaf breakdown rates a useful measure of stream integrity along an agricultural landuse gradient? Journal of the North American Benthological Society 25(2):330-343.

Haggerty, S. M., D. P. Batzer, and C. R. Jackson. 2002. Macroinvertebrate assemblages in perennial headwater streams of the coastal mountain range of washington, u.S.A. Hydrobiologia 479(1):143-154.

Hartman, K. J., M. D. Kaller, J. W. Howell, and J. A. Sweka. 2005. How much do valley fills influence headwater streams? Hydrobiologia 532(1):91-102. 
Hassan, M. A., Hogan, D. L., Bird, S. A., May, C. L., Gomi, T., Campbell, D. 2005. Spatial and temporal dynamics of wood in headwater streams of the pacific northwest. Journal of the American Water Resources Association 41(4):899919.

Hieber, M., and M. O. Gessner. 2002. Contribution of stream detrivores, fungi, and bacteria to leaf breakdown based on biomass estimates. Ecology 83(4):10261038.

Hoover, T. M., J. S. Richardson, and N. Yonemitsu. 2006. Flow-substrate interactions create and mediate leaf litter resource patches in streams. Freshwater Biology 51(3):435-447.

Huryn, A. D., V. M. Butz Huryn, C. J. Arbuckle, and L. Tsomides. 2002. Catchment land-use, macroinvertebrates and detritus processing in headwater streams: Taxonomic richness versus function. Freshwater Biology 47(3):401-415.

Jones, J. B., Jr., and L. A. Smock. 1991. Transport and retention of particulate organic matter in two low-gradient headwater streams. Journal of the North American Benthological Society 10(2):115-126.

Kiffney, P. M., J. S. Richardson, and J. P. Bull. 2004. Establishing light as a causal mechanism structuring stream communities in response to experimental manipulation of riparian buffer width. Journal of the North American Benthological Society 23(3):542-555.

Kobayashi, S., and T. Kagaya. 2005. Hot spots of leaf breakdown within a headwater stream reach: Comparing breakdown rates among litter patch types with different macroinvertebrate assemblages. Freshwater Biology 50(6):921929.

Lamberti, G. A., Gregory, S. V. 1996. Transport and retention of cpom. F. R. Hauer, and G. A. Lamberti, editors. Methods in stream ecology. Academic Press, New York.

Latterell, J. J., Bechtold, J. S., O'Keefe, T. C., Pelt, R., Naiman, R. J. 2006. Dynamic patch mosaics and channel movement in an unconfined river valley of the olympic mountains. Freshwater Biology 51(3):523-544.

Lepori, F., D. Palm, and B. Malmqvist. 2005. Effects of stream restoration on ecosystem functioning: Detritus retentiveness and decomposition. Journal of Applied Ecology 42(2):228-238.

McCabe, D. J., Sykora, J. L. . 2000. Community structure of caddisflies along a temperate springbrook. Archiv Fur Hydrobiologie 148(2):263-282. 
Merricks, C., D. Cherry, C. Zipper. 2003. Evaluation of hollow fill drainages and associated settling ponds on water quality and benthic macroinvertebrate communities of va and wv. In: 2003 Powell River Project Research and Education Reports.

Merritt, R. W., Cummins, K. W., Berg, M. B. 2008. An introduction to the aquatic insects of north america, 4th edition. Kendall Hunt Publishing.

Messinger, T. 2003. Comparison of storm response of streams in small, unmined and valley-filled watersheds, 1999-2001, ballard fork, west virginia. Charleston, WV.

Meyer, J. L., Wallace, J. B. 2001. Lost linkages and lotic ecology: Rediscovering small streams. Pages 295-316 in M. C. Press, Huntly, N. J., Levin, S. , editor. Ecology: Achievement and challenge. Blackwell, Oxford, U.K.

Millington, C. E., and D. A. Sear. 2007. Impacts of river restoration on small-wood dynamics in a low-gradient headwater stream. Earth Surface Processes and Landforms 32(8):1204-1218.

Minshall, G. W., and coauthors. 1983. Interbiome comparison of stream ecosystem dynamics. Ecological Monographs 53(1):2-25.

Mulholland, P. J., A. V. Palumbo, J. W. Elwood, and A. D. Rosemond. 1987. Effects of acidification on leaf decomposition in streams. Journal of the North American Benthological Society 6(3):147-158.

Naiman, R. J., J. M. Melillo, M. A. Lock, T. E. Ford, and S. R. Reice. 1987. Longitudinal patterns of ecosystem processes and community structure in a subarctic river continuum. Ecology 68(5):1139-1156.

Niyogi, D. K., W. M. Lewis, and D. M. McKnight. 2001. Litter breadown in mountain streams affected by mine drainage: Biotic mediation of abiotic controls. Ecological Applications 11(2):506-516.

Niyogi, D. K., D. M. McKnight, and W. M. Lewis. 2002. Effects of mine drainage on breakdown of aspen litter in mountain streams. Water, Air, \& Soil Pollution: Focus 2(2):329-341.

Pascoal, C., F. Cassio, and P. Gomes. 2001. Leaf litter processing and invertebrates leaf breakdown rates: A measure of water quality? International Review of Hydrobiology 86(4-5):407-416.

Paul, M. J., Meyer, J. L., Couch, C. A. 2006. Leaf breakdown in streams differing in catchment land use. Freshwater Biology 51(9):1684-1695. 
Paybins, K. S. 2003. Flow origin, drainage area, and hydrologic characteristics for headwater streams in the mountaintop coal-mining region of southern west virginia, 2000-01. Charleston, WV.

Petersen, R. C., and K. W. Cummins. 1974. Leaf processing in a woodland stream. Freshwater Biology 4:343-368.

Petty, J., Freund, J., Lamothe, P., Mazik, P. 2001. Quantifying instream habitat in the upper shavers fork basin at multiple spatial scales. Proceedings of the Southeastern Association of Fish and Wildlife Agencies 55:81-94.

Phillips, J. 2004. Impacts of surface mine valley fills on headwater floods in eastern kentucky. Environmental Geology 45:367-380.

Pond, G. J. 2004. Effects of surface mining and residential land use on headwater stream biotic integrity. Water Quality Branch Ecological Support Section, editor. Kentucky Department of Environmental Protection Division of Water.

Pond, G. J., M. E. Passmore, F. A. Borsuk, L. Reynolds, and C. J. Rose. 2008. Downstream effects of mountaintop coal mining: Comparing biological conditions using family- and genus-level macroinvertebrate bioassessment tools. Journal of the North American Benthological Society 27(3):717-737.

R Development Core Team. 2009. R: A language and environment for statistical computing. R Foundation for Statistical Computing Vienna, Austria.

Richardson, J. S., and R. J. Danehy. 2007. A synthesis of the ecology of headwater streams and their riparian zones in temperate forests. Forest Science 53:131147.

Riis, T., Sand-Jensen, K. 2006. Dispersal of plant fragments in small streams. Freshwater Biology 51(2):274-286.

Rosgen, D. 2001. A practical method of computing streambank erosion rate. Pages 18-26 in Proceedings of the Seventh Federal Interagency Sedimentation Conference, Reno, NV.

Simon, K. S., M. A. Simon, and E. F. Benfield. 2009. Variation in ecosystem function in appalachian streams along an acidity gradient. Ecological Applications 19(5):1147-1160.

Slonecker, E. T., Benger, M.J. 2001. Remote sensing and mountaintop mining. Remote Sensing Reviews 20(4):293-322.

Speaker, R., Moore, K., Gregory, S. 1984. Analysis of the process of retention of organic matter in stream ecosystems. Verhandlung Internationale Vereinigung Limnologie 22:1835-1841. 
Sponseller, R. A., and E. F. Benfield. 2001. Influences of land use on leaf breakdown in southern appalachian headwater streams: A multiple-scale analysis. Journal of the North American Benthological Society 20(1):44-59.

Strager, M. P., J. T. Petty, J. M. Strager, and J. Barker-Fulton. 2009. A spatially explicit framework for quantifying downstream hydrologic conditions. Journal of Environmental Management 90(5):1854-1861.

Suberkropp, K., and E. Chauvet. 1995. Regulation of leaf breakdown by fungi in streams: Influences of water chemistry. Ecology 76(5):1433-1445.

Swanson, F. J., S. L. Johnson, S. V. Gregory, and S. A. Acker. 1998. Flood disturbance in a forested mountain landscape. BioScience 48(9):681-689.

United States Environmental Protection Agency. 2005. Mountaintop mining/valley fills in appalachia final programmatic environmental impact statement.

Vannote, R. L., G. W. Minshall, K. W. Cummins, J. R. Sedell, and C. E. Cushing. 1980. The river contiuum concept. Canadian Journal of Fisheries and Aquatic Sciences 37(1):130-137.

Wallace, J. B., S. L. Eggert, J. L. Meyer, and J. R. Webster. 1997. Multiple trophic levels of a forest stream linked to terrestrial litter inputs. Science 277(5322):102104.

Wallace, J. B., S. L. Eggert, J. L. Meyer, and J. R. Webster. 1999. Effects of resource limitation on a detrital-based ecosystem. Ecological Monographs 69(4):409442.

Wallace, J. B., J. R. Webster, and T. F. Cuffney. 1982. Stream detritus dynamics: Regulation by invertebrate consumers. Oecologia 53(2):197-200.

Wallace, J. B., and coauthors. 1995. Long-term dynamics of coarse particulate organic matter in three appalachian mountain streams. Journal of the North American Benthological Society 14(2):217-232.

Webster, J. R., and E. F. Benfield. 1986. Vascular plant breakdown in freshwater ecosystems. Annual Review of Ecology and Systematics 17(1):567-594.

Webster, J. R., and coauthors. 1999. What happens to allochthonous material that falls into streams? A synthesis of new and published information from coweeta. Freshwater Biology 41(4):687-705.

Webster, J. R., A. P. Covich, J. L. Tank, and T. V. Crockett. 1994. Retention of coarse organic particles in streams in the southern appalachian mountains. Journal of the North American Benthological Society 13(2):140-150. 
Wigington, P. J., and coauthors. 2006. Coho salmon dependence on intermittent streams. Frontiers in Ecology and the Environment 4(10):513-518.

Wiley, J. B., and F. D. Brogan. 2003. Comparison of peak discharges among sites with and without valley fills for the july 8-9, 2001, flood in the headwaters of clear fork, coal river basin, mountaintop coal-mining region, southern west virginia. U.S. Department of the Interior, editor. U.S. Geological Survey.

Wiley, J. B., R. D. Evaldi, J. H. Eychaner, and D. B. Chambers. 2001. Reconnaissance of stream geomorphology, low streamflow, and stream temperature in the mountaintop coal-mining region, southern west virginia, 1999-2000, US Geological Survey Water-Resources Investigations Report 01-4092.

Wipfli, M. S. 2005. Trophic linkages between headwater forests and downstream fish habitats: Implications for forest and fish management. Landscape and Urban Planning 72(1-3):205-213.

Wipfli, M. S., and D. P. Gregovich. 2002. Export of invertebrates and detritus from fishless headwater streams in southeastern alaska: Implications for downstream salmonid production. Freshwater Biology 47(5):957-969.

Wolman, M. G. 1954. A method of sampling coarse river-bed material. Trans. Am. Geophys. Union 35:951-956. 
Table 1: Dates for organic matter variables measured.

\begin{tabular}{lcc}
\hline & $\begin{array}{c}\text { Organic Matter } \\
\text { Transport }\end{array}$ & $\begin{array}{c}\text { Organic Matter } \\
\text { Decomposition }\end{array}$ \\
\hline Fall 2007 & $11 / 18 / 07-12 / 30 / 07$ & $11 / 18 / 07-3 / 23 / 08$ \\
Spring 2008 & $3 / 23 / 08-5 / 3 / 08$ & $3 / 23 / 08-7 / 23 / 08$ \\
Summer 2008 & $7 / 23 / 08-9 / 10 / 08$ & $7 / 23 / 08-11 / 6 / 08$ \\
\hline
\end{tabular}


Table 2: Descriptive variables (basin area and gradient) measured at all sites involved in the study.

\begin{tabular}{llcc}
\hline Site & Type & Basin Area $\left(\mathrm{km}^{2}\right)$ & Gradient (\% Slope) \\
\hline E 1 & Ephemeral & 0.16 & 18.0 \\
E 2 & Ephemeral & 0.18 & 11.0 \\
E 3 & Ephemeral & 0.24 & 28.0 \\
I 1 & Intermittent & 0.43 & 4.5 \\
I 2 & Intermittent & 0.50 & 8.0 \\
I 3 & Intermittent & 0.54 & 4.5 \\
SP 1 & Small Perennial & 1.43 & 2.0 \\
SP 2 & Small Perennial & 1.55 & 2.3 \\
SP 3 & Small Perennial & 1.65 & 5.7 \\
SP 4 & Small Perennial & 2.12 & 3.5 \\
SP 5 & Small Perennial & 2.31 & 2.3 \\
SP 6 & Small Perennial & 2.85 & 2.7 \\
SP 7 & Small Perennial & 3.43 & 2.0 \\
SP 8 & Small Perennial & 0.80 & 2.5 \\
SP 9 & Small Perennial & 0.86 & 6.0 \\
SP 10 & Small Perennial & 0.98 & 2.3 \\
SP 11 & Small Perennial & 1.09 & 2.6 \\
MP 1 & Medium Perennial & 10.09 & 1.7 \\
MP 2 & Medium Perennial & 20.87 & 1.0 \\
MP 3 & Medium Perennial & 31.93 & 0.7 \\
LP 1 & Large Perennial & 41.77 & 1.4 \\
LP 2 & Large Perennial & 65.67 & 1.0 \\
LP 3 & Large Perennial & 165.41 & 1.0 \\
\hline
\end{tabular}


Table 3: Principle components analysis (PCA) results. PCA was used to group habitat variables into one variable that could be used for "structural complexity." PC 1 was used to represent structural complexity.

\begin{tabular}{lcc}
\hline & PC 1 & PC 2 \\
\hline Eigenvalue & 3.34 & 1.21 \\
Total Variance Explained & 55.65 & 75.77 \\
Total Retentive Score & +0.9140 & $\cdot$ \\
Number of Retentive Features per m & +0.8103 & $\cdot$ \\
Large Woody Debris per m & +0.7917 &. \\
Rapid Visual Habitat Assessment & +0.7372 & -0.5602 \\
Coefficient of Variation of Depth & +0.5135 & +0.7946 \\
Mean Distance to Retentive Feature & -0.6426 &. \\
\hline
\end{tabular}


Table 4: Habitat variables and organic matter transport distances measured at each site.

\begin{tabular}{|c|c|c|c|c|c|c|c|c|}
\hline Site & Type & $\begin{array}{l}\text { Retentive } \\
\text { Score }\end{array}$ & $\begin{array}{l}\text { RVHA } \\
\text { Score }\end{array}$ & $\begin{array}{c}\text { LWD } \\
\text { per } \\
100 \mathrm{~m}\end{array}$ & $\begin{array}{c}\text { CV of } \\
\text { Depth } \\
(\%)\end{array}$ & $\begin{array}{c}\text { Number of } \\
\text { Retentive } \\
\text { Features/ } 100 \\
\text { m }\end{array}$ & $\begin{array}{c}\text { Average } \\
\text { Dowel } \\
\text { Transport } \\
\text { Distance } \\
\text { (m/6 weeks) }\end{array}$ & $\begin{array}{l}\text { Average } \\
\text { Leaf } \\
\text { Transport } \\
\text { Distance } \\
\text { (m/hour) }\end{array}$ \\
\hline E 1 & Ephemeral & 15 & $68 \%$ & 12 & 130 & 13 & 0 & 0 \\
\hline E 2 & Ephemeral & 17 & $71 \%$ & 15 & 58 & 6 & 0 & 0 \\
\hline E 3 & Ephemeral & 17 & $62 \%$ & 25 & 130 & 2 & 10 & 3 \\
\hline I 1 & Intermittent & 19 & $58 \%$ & 23 & 542 & 11 & 1 & 1 \\
\hline I 2 & Intermittent & 13 & $51 \%$ & 19 & 483 & 16 & 3 & 0 \\
\hline I 3 & Intermittent & 16 & $67 \%$ & 23 & 150 & 2 & 8 & 4 \\
\hline SP 1 & Small Perennial & 3 & $28 \%$ & 11 & 116 & 2 & 11 & 3 \\
\hline SP 2 & Small Perennial & 15 & $70 \%$ & 23 & 49 & 3 & 13 & 3 \\
\hline SP 3 & Small Perennial & 8 & $53 \%$ & 12 & 82 & 6 & 10 & 3 \\
\hline SP 4 & Small Perennial & 2 & $43 \%$ & 11 & 72 & 0 & 19 & 6 \\
\hline SP 5 & Small Perennial & 4 & $46 \%$ & 1 & 66 & 0 & 12 & 2 \\
\hline SP 6 & Small Perennial & 4 & $54 \%$ & 0 & 47 & 1 & 19 & 9 \\
\hline SP 7 & Small Perennial & 3 & $48 \%$ & 6 & 62 & 0 & 12 & 10 \\
\hline SP 8 & Small Perennial & 13 & $65 \%$ & 32 & 91 & 5 & 7 & 2 \\
\hline SP 9 & Small Perennial & 17 & $73 \%$ & 63 & 82 & 11 & 9 & 2 \\
\hline SP 10 & Small Perennial & 13 & $65 \%$ & 5 & 65 & 5 & 12 & 9 \\
\hline SP 11 & Small Perennial & 12 & $72 \%$ & 23 & 96 & 8 & 9 & 1 \\
\hline MP 1 & Medium Perennial & 4 & $57 \%$ & 3 & 39 & 3 & 35 & 33 \\
\hline MP 2 & Medium Perennial & 3 & $49 \%$ & 3 & 28 & 0 & 41 & 40 \\
\hline MP 3 & Medium Perennial & 5 & $44 \%$ & 13 & 58 & 1 & 58 & 65 \\
\hline LP 1 & Large Perennial & 6 & $60 \%$ & 2 & 47 & 1 & 68 & 55 \\
\hline LP 2 & Large Perennial & 9 & $44 \%$ & 1 & 88 & 4 & 65 & 100 \\
\hline LP 3 & Large Perennial & 12 & $61 \%$ & 9 & 54 & 2 & 124 & 192 \\
\hline
\end{tabular}


Table 5: Habitat variables across different basin area types for all sites included in the study (average (standard deviation)).

\begin{tabular}{lccccc}
\hline & Ephemeral & Intermittent & Small Perennial & $\begin{array}{c}\text { Medium } \\
\text { Perennial }\end{array}$ & Large Perennial \\
\hline $\begin{array}{l}\text { Drainage Area } \\
\left(\mathrm{km}^{2}\right)\end{array}$ & $0.16-0.18$ & $0.43-0.53$ & $0.80-3.40$ & $10.1-31.9$ & $41.8-164.4$ \\
$\begin{array}{l}\text { Channel Width } \\
(\mathrm{m})\end{array}$ & $1.4(0.4)$ & $1.8(0.6)$ & $2.5(0.2)$ & $5.7(1.4)$ & $12.0(2.2)$ \\
Gradient & $19.0(4.9)$ & $5.7(1.2)$ & $3.1(0.4)$ & $1.1(0.3)$ & $1.1(0.1)$ \\
$\begin{array}{l}\% \text { slope }) \\
\text { RVHA Score }\end{array}$ & $134(5)$ & $117(10)$ & $112(9)$ & $99(7)$ & $109(11)$ \\
$\begin{array}{l}\text { LWD per meter } \\
\text { CV of Depth }\end{array}$ & $17(4)$ & $22(1)$ & $17(6)$ & $6(3)$ & $4(2)$ \\
$\begin{array}{l}\text { Mean distance to } \\
\text { Retentive Feature }(\mathrm{m})\end{array}$ & $130.2(0)$ & $391.7(121.9)$ & $75.4(20.6)$ & $41.1(8.6)$ & $62.7(12.7)$ \\
$\begin{array}{l}\text { Canopy Cover } \\
(\%)\end{array}$ & $13.2(3.6)$ & $7.7(2.7)$ & $17.0(3.9)$ & $58.0(39.9)$ & $17.5(8.2)$ \\
$\begin{array}{l}\text { Average Temperature } \\
\left({ }^{\circ} \mathrm{C}\right)\end{array}$ & $12.82(0.412)$ & $13.60(0.79)$ & $12.19(0.78)$ & $14.54(0.18)$ & $14.76(0.04)$ \\
$\begin{array}{l}\text { Average Minimum } \\
\text { Temperature }\left({ }^{\circ} \mathrm{C}\right)\end{array}$ & $-5.02(3.5)$ & $-0.86(1.9)$ & $0.96(0.5)$ & $0.96(0.5)$ & $-1.15(1.1)$ \\
$\begin{array}{l}\text { Average Maximum } \\
\text { Temperature }\left({ }^{\circ} \mathrm{C}\right)\end{array}$ & $27.99(0.31)$ & $33.89(5.00)$ & $24.51(0.49)$ & $27.30(0.31)$ & $24.47(0.14)$ \\
Conductivity $(\mu \mathrm{S} / \mathrm{cm})$ & $49(3)$ & $379(406)$ & $515(108)$ & $616(35)$ & $849(131)$ \\
\hline
\end{tabular}


Table 6: Average organic matter transport distance for dowels and artificial leaves for each basin area type. Values in parentheses represent standard error of the mean. There was a positive relationship between organic matter transport rates and basin area.

\begin{tabular}{|c|c|c|c|c|c|}
\hline & Ephemeral & Intermittent & Small Perennial & $\begin{array}{l}\text { Medium } \\
\text { Perennial }\end{array}$ & Large Perennial \\
\hline \multicolumn{6}{|l|}{ Average Dowel Transport } \\
\hline Fall 2007 (m/6 weeks) & $3.1(3.1)$ & $0.0(0.0)$ & $9.5(1.8)$ & $41.8(10.1)$ & $66.0(15.1)$ \\
\hline Spring 2008 (m/6 weeks) & $6.0(6.0)$ & $6.7(5.0)$ & $17.3(1.4)$ & $54.7(5.6)$ & $117.0(31.2)$ \\
\hline Summer 2008 (m/6 weeks) & $1.1(1.1)$ & $5.0(2.6)$ & $9.6(1.3)$ & $37.8(6.5)$ & $74.0(12.5)$ \\
\hline All Seasons (m/6 weeks) & $3.4(3.4)$ & $3.9(1.2)$ & $12.1(1.1)$ & $44.7(6.9)$ & $85.7(19.2)$ \\
\hline \multicolumn{6}{|l|}{ Average Leaf Transport } \\
\hline Fall 2007 (m/6 weeks) & $0.0(0.0)$ & $0.0(0.0)$ & $0.3(0.1)$ & $13.7(1.8)$ & $48.9(15.5)$ \\
\hline Spring 2008 (m/6 weeks) & $1.7(1.7)$ & $2.5(1.9)$ & $6.4(1.3)$ & $45.9(8.9)$ & $105.4(36.6)$ \\
\hline Summer 2008 (m/6 weeks) & $0.0(0.0)$ & $0.0(0.0)$ & $0.2(0.1)$ & $9.4(4.2)$ & $19.3(8.8)$ \\
\hline All Seasons (m/6 weeks) & $0.6(0.6)$ & $0.6(0.6)$ & $2.3(0.5)$ & $23.0(4.9)$ & $57.9(20.2)$ \\
\hline
\end{tabular}


Table 7: Average decomposition rates and processing ability for each stream type. Values in parentheses represent standard error of the mean. There was no significant difference in decomposition rates across different stream types.

\begin{tabular}{lccccc}
\hline & Ephemeral & Intermittent & Small Perennial & $\begin{array}{c}\text { Medium } \\
\text { Perennial }\end{array}$ & Large Perennial \\
\hline $\begin{array}{l}\text { Average Decomposition }\left(g^{-1}\right) \\
\quad \text { Fall } 2007\end{array}$ & $0.0024(0.0003)$ & $0.0046(0.0010)$ & $0.0029(0.0008)$ & $0.0044(0.0003)$ & $0.0054(0.0024)$ \\
Spring 2008 & $0.0020(0.0014)$ & $0.0037(0.0034)$ & $0.0035(0.0003)$ & $0.0085(0.0068)$ & $0.0033(0.0016)$ \\
Summer 2008 & $0.0029(0.0010)$ & $0.0024(0.0016)$ & $0.0051(0.0010)$ & $0.0063(0.0016)$ & $0.0075(0.0029)$ \\
Overall & $0.0044(0.0002)$ & $0.0042(0.0006)$ & $0.0039(0.0003)$ & $0.0049(0.0001)$ & $0.0045(0.0015)$ \\
& & & & & \\
Processing ability & & & & & \\
Fall 2007 & $0.0011(0.0002)$ & $0.0010(0.0001)$ & $0.0003(0.0001)$ & $1.9 \mathrm{E}-6(5.8 \mathrm{E}-7)$ & $2.0 \mathrm{E}-6(5.3 \mathrm{E}-7)$ \\
Spring 2008 & $0.0009(0.0006)$ & $0.0002(0.0001)$ & $0.0001(0.0000)$ & $2.7 \mathrm{E}-6(2.0 \mathrm{E}-6)$ & $8.1 \mathrm{E}-7(4.3 \mathrm{E}-7)$ \\
Summer 2008 & $0.0014(0.0006)$ & $0.0003(0.0002)$ & $0.0004(0.0001)$ & $1.8 \mathrm{E}-5(1.6 \mathrm{E}-5)$ & $2.4 \mathrm{E}-6(8.8 \mathrm{E}-7)$ \\
\hline
\end{tabular}


Table 8: Average decomposition, water conductivity, and temperature for each site where leaf decomposition was measured. All temperatures are in degrees Celsius. Temperature was measured continuously throughout the study period.

Decomposition averages are averaged across three seasons.

\begin{tabular}{llcccccccc}
\hline Site & Type & $\begin{array}{c}\text { Average } \\
\text { Decomp } \\
\left(\mathrm{g}^{-1}\right)\end{array}$ & $\begin{array}{c}\text { Conductivity } \\
(\mu \mathrm{S} / \mathrm{cm})\end{array}$ & $\begin{array}{c}\text { Average } \\
\text { Temp }\end{array}$ & $\begin{array}{c}\text { CV } \\
\text { Temp }\end{array}$ & $\begin{array}{c}\text { Max } \\
\text { Daily } \\
\text { Temp CV }\end{array}$ & $\begin{array}{c}\text { Mean } \\
\text { Daily } \\
\text { Temp CV }\end{array}$ & $\begin{array}{c}\text { Max Daily } \\
\text { Temp } \\
\text { Range }\end{array}$ & $\begin{array}{c}\text { Mean } \\
\text { Daily } \\
\text { Temp } \\
\text { Range }\end{array}$ \\
\hline E3 & E & 0.0042 & 51 & 12.4 & 54.1 & 2.2 & 0.1 & 16.6 & 3.6 \\
E2 & E & 0.0046 & 46 & 13.2 & 39.3 & 1.4 & 0.1 & 24.2 & 3.0 \\
I3 & I & 0.0048 & 73 & 12.8 & 49.4 & 3.2 & 3.2 & 17.2 & 2.2 \\
I2 & I & 0.0036 & 686 & 14.4 & 40.8 & 1.4 & 0.1 & 24.3 & 5.2 \\
SP10 & SP & 0.0030 & 60 & 14.7 & 31.4 & 0.5 & 0.1 & 16.3 & 2.9 \\
SP8 & SP & 0.0047 & 71 & 10.7 & 57.2 & 1.7 & 0.1 & 4.1 & 2.2 \\
SP11 & SP & 0.0041 & 748 & 10.8 & 43.0 & 0.5 & 0.1 & 15.2 & 2.4 \\
SP9 & SP & 0.0032 & 654 & 11.4 & 52.5 & 1.2 & 0.1 & 3.6 & 2.3 \\
MP3 & MP & 0.0050 & 581 & 14.4 & 43.0 & 1.5 & 0.1 & 15.2 & 3.7 \\
MP2 & MP & 0.0048 & 651 & 14.7 & 48.7 & 2.8 & 0.1 & 18.1 & 4.4 \\
LP2 & LP & 0.0030 & 980 & 14.8 & 48.5 & 2.3 & 0.1 & 16.4 & 3.4 \\
LP1 & LP & 0.0060 & 718 & 14.7 & 48.7 & 1.7 & 0.1 & 15.6 & 4.5 \\
\hline
\end{tabular}


Table 9: Seasonal decomposition rates and processing ability for each site where decomposition was measured.

\begin{tabular}{|c|c|c|c|c|c|c|c|}
\hline \multicolumn{5}{|c|}{ Decomposition $\left(\mathrm{g}^{-1}\right)$} & \multicolumn{3}{|c|}{ Processing ability } \\
\hline Site & $\begin{array}{l}\text { Fall } 2007 \\
\qquad\left(g^{-1}\right)\end{array}$ & Spring 2008 & $\begin{array}{c}\text { Summer } 2008 \\
\left(\mathrm{~g}^{-1}\right)\end{array}$ & $\begin{array}{c}\text { Overall } \\
\text { Average }\left(\mathrm{g}^{-1}\right)\end{array}$ & Fall 2007 & Spring 2008 & Summer 2008 \\
\hline E3 & 0.0027 & 0.0006 & 0.0039 & 0.0046 & 0.0013 & 0.0003 & 0.0019 \\
\hline E2 & 0.0021 & 0.0033 & 0.0019 & 0.0042 & 0.0009 & 0.0014 & 0.0008 \\
\hline I3 & 0.0036 & 0.0003 & 0.0008 & 0.0036 & 0.0011 & 0.0001 & 0.0001 \\
\hline $\mathrm{I} 2$ & 0.0056 & 0.0071 & 0.0040 & 0.0048 & 0.0009 & 0.0002 & 0.0004 \\
\hline SP10 & 0.0077 & 0.0049 & 0.0103 & 0.0060 & 0.0000 & 0.0000 & 0.0000 \\
\hline SP8 & 0.0030 & 0.0017 & 0.0046 & 0.0030 & 0.0000 & 0.0000 & 0.0000 \\
\hline SP11 & 0.0047 & 0.0017 & 0.0047 & 0.0048 & 0.0000 & 0.0000 & 0.0000 \\
\hline SP9 & 0.0040 & 0.0152 & 0.0079 & 0.0050 & 0.0000 & 0.0000 & 0.0000 \\
\hline MP3 & 0.0038 & 0.0028 & 0.0063 & 0.0030 & 0.0000 & 0.0000 & 0.0002 \\
\hline MP2 & 0.0048 & 0.0030 & 0.0044 & 0.0041 & 0.0006 & 0.0001 & 0.0002 \\
\hline LP2 & 0.0018 & 0.0039 & 0.0037 & 0.0047 & 0.0001 & 0.0001 & 0.0007 \\
\hline LP1 & 0.0013 & 0.0028 & 0.0075 & 0.0032 & 0.0003 & 0.0001 & 0.0006 \\
\hline
\end{tabular}


Table 10: Correlations between average decomposition rate $\left(\mathrm{g}^{-1}\right)$ and water quality and macroinvertebrate data. There was not a single variable that was significantly related to average decomposition rate.

\begin{tabular}{lccc}
\hline Variable & Correlation & $\mathrm{df}$ & Signif Prob \\
\hline Coefficient of Variation of Temperature & -0.0473 & 11 & 0.8838 \\
Maximum Temperature $\left({ }^{\circ} \mathrm{C}\right)$ & 0.3093 & 11 & 0.3279 \\
Minimum Temperature $\left({ }^{\circ} \mathrm{C}\right)$ & 0.0114 & 11 & 0.9720 \\
Average Temperature $\left({ }^{\circ} \mathrm{C}\right)$ & 0.2200 & 11 & 0.4920 \\
Conductivity $(\mu \mathrm{S} / \mathrm{cm})$ & -0.0710 & 11 & 0.8265 \\
Maximum Daily Temperature Coefficient of & 0.2321 & 11 & 0.4679 \\
Variation & 0.0193 & 11 & 0.9524 \\
Maximum Temperature Daily Range $\left({ }^{\circ} \mathrm{C}\right)$ & 0.1922 & 11 & 0.5495 \\
Mean Daily Temperature Coefficient of Variation & 0.2024 & 11 & 0.5282 \\
$\left({ }^{\circ} \mathrm{C}\right)$ & -0.3512 & 11 & 0.2629 \\
Mean Daily Temperature Range $\left({ }^{\circ} \mathrm{C}\right)$ & 0.3435 & 11 & 0.2744 \\
Overall \% collector gatherer & -0.0209 & 11 & 0.9486 \\
Overall \% other & -0.2108 & 11 & 0.5109 \\
Overall \% predator & & & \\
Overall \% shredders &
\end{tabular}


Table 11: Correlations between structural complexity variables and average dowel transport distance. Correlation coefficient is listed first followed by the p-value.

\begin{tabular}{lccc}
\hline Variable & $\begin{array}{c}\text { Ephemeral and } \\
\text { Intermittent }\end{array}$ & $\begin{array}{c}\text { Small } \\
\text { Perennial }\end{array}$ & $\begin{array}{c}\text { Medium and } \\
\text { Large Perennial }\end{array}$ \\
\hline CV of Depth (\%) & $0.5399(0.2689)$ & $-0.5740(0.0252)$ & $0.3092(0.5510)$ \\
Large Woody Debris per m & $0.4795(0.3358)$ & $-0.4326(0.1073)$ & $0.3934(0.4403)$ \\
Mean distance to retentive feature (m) & $-0.3150(0.5432)$ & $0.3006(0.2763)$ & $-0.4241(0.4020)$ \\
Principle Component 1 & $-0.5210(0.2892)$ & $-0.5209(0.0465)$ & $0.6688(0.1464)$ \\
Retentive Features per m & $-0.0758(0.8865)$ & $-0.4949(0.0625)$ & $0.0467(0.9300)$ \\
Retentive Score & $-0.2438(0.6416)$ & $-0.5760(0.0246)$ & $0.9151(0.0105)$ \\
RVHA Score & $-0.2721(0.6020)$ & $-0.3755(0.1678)$ & $0.4338(0.3902)$ \\
\hline
\end{tabular}


Table 12: Correlations between structural complexity variables and average leaf transport distance. Correlation coefficient is listed first followed by the p-value.

\begin{tabular}{lccc}
\hline Variable & $\begin{array}{c}\text { Ephemeral and } \\
\text { Intermittent }\end{array}$ & $\begin{array}{c}\text { Small } \\
\text { Perennial }\end{array}$ & $\begin{array}{c}\text { Medium and } \\
\text { Large Perennial }\end{array}$ \\
\hline CV of Depth (\%) & $-0.0070(0.9895)$ & $-0.4469(0.0949)$ & $0.4136(0.4150)$ \\
Large Woody Debris per m & $0.3732(0.4662)$ & $-0.4036(0.1357)$ & $0.3780(0.4600)$ \\
Mean distance to retentive feature (m) & $0.0191(0.9713)$ & $-0.1232(0.6617)$ & $-0.4357(0.3878)$ \\
Principle Component 1 & $-0.5262(0.2836)$ & $-0.3500(0.1494)$ & $0.6690(0.1462)$ \\
Retentive Features per m & $-0.4798(0.3356)$ & $-0.3733(0.1705)$ & $0.1890(0.7199)$ \\
Retentive Score & $0.2780(0.5937)$ & $-0.4105(0.1285)$ & $0.9522(0.0034)$ \\
RVHA Score & $0.2301(0.6610)$ & $-0.2078(0.4574)$ & $0.2749(0.5980)$ \\
\hline
\end{tabular}


Table 13: Multiple regression models for dowel transport distance (PC 1 and average gradient used as predictors). The results show that structural complexity (PC 1 was used to represent structural complexity in habitat conditions) is important for organic matter transport in small perennial streams.

\begin{tabular}{llll}
\hline Ephemeral/Intermittent Sites: Dowels & & \\
\hline Term & Estimate & $\mathrm{R}^{2}$ & $\mathrm{p}$-value \\
Intercept & 9.25 & & 0.08 \\
Principle Component 1 & -3.23 & 0.3626 & 0.21 \\
Model & & 0.3626 & 0.21 \\
\hline Small Perennial Sites: Dowels & & \\
\hline Term & Estimate & $\mathrm{R}^{2}$ & $\mathrm{p}$-value \\
Intercept & 11.77 & & $<0.001$ \\
Principle Component 1 & -1.30 & 0.3622 & $0.05^{*}$ \\
Model & & 0.3622 & $0.05^{*}$ \\
\hline Medium and Large Perennial Sites: Dowels & & \\
\hline Term & Estimate & $\mathrm{R}^{2}$ & $\mathrm{p}$-value \\
Intercept & 91.64 & & 0.01 \\
Principle Component 1 & 18.97 & 0.4473 & 0.15 \\
Model & & 0.4473 & 0.15 \\
\hline
\end{tabular}


Table 14: Multiple regression models for artificial leaf transport distance (PC 1 and average gradient used as predictors).

\begin{tabular}{llll}
\hline \multicolumn{3}{l}{ Ephemeral/Intermittent } & \multicolumn{3}{l}{ Sites: Artificial Leaves } & \\
\hline Term & Estimate & $\mathrm{R}^{2}$ & $\mathrm{p}$-value \\
Intercept & 1.98 & & 0.08 \\
Principle Component 1 & -0.74 & 0.3998 & 0.18 \\
Model & & 0.3998 & 0.18 \\
\hline Small Perennial Sites: Artificial Leaves & & \\
\hline Term & Estimate & $\mathrm{R}^{2}$ & $\mathrm{p}$-value \\
Intercept & 2.19 & & 0.001 \\
Principle Component 1 & -0.45 & 0.2164 & 0.15 \\
Model & & 0.2164 & 0.15 \\
\hline Medium and Large Perennial Sites: Leaves & & \\
\hline Term & Estimate & $\mathrm{R}^{2}$ & $\mathrm{p}$-value \\
Intercept & 65.28 & & 0.02 \\
Principle Component 1 & 17.84 & 0.4476 & 0.15 \\
Model & & 0.4476 & 0.15 \\
\hline
\end{tabular}


Table 15: Multiple regression models for processing ability (PC 1 and conductivity used as predictors). None of the models were significant.

\begin{tabular}{|c|c|c|c|}
\hline Term & Estimate & $\mathrm{R}^{2}$ & p-value \\
\hline \multicolumn{4}{|c|}{ Fall 2007} \\
\hline Intercept & 0.0007 & & 0.25 \\
\hline Conductivity & $-7.4 \mathrm{E}-7$ & 0.4208 & 0.47 \\
\hline Principle Component 1 & 0.0002 & 0.2850 & 0.08 \\
\hline Model & & 0.5217 & 0.07 \\
\hline \multicolumn{4}{|c|}{ Spring 2008} \\
\hline Intercept & 0.0003 & & 0.05 \\
\hline Conductivity & $-4.7 \mathrm{E}-7$ & 0.1942 & 0.15 \\
\hline Model & & 0.1942 & 0.15 \\
\hline \multicolumn{4}{|c|}{ Summer 2008} \\
\hline Intercept & 0.0007 & & 0.01 \\
\hline Conductivity & $-8.3 \mathrm{E}-7$ & 0.3039 & 0.06 \\
\hline Model & & 0.3039 & 0.06 \\
\hline
\end{tabular}


Table 16: Relative processing ability among all stream sizes (e.g. intermittent sites have $2 \mathrm{x}$ lower processing ability than ephemeral sites and ephemeral sites have a range of processing ability values from 0.0003 to 0.0019 ). Values in parentheses represent the range of drainage areas covered by each stream type.

\begin{tabular}{lll}
\hline Stream Type & Compared to & Range \\
\hline & Ephemeral & $0.0003-0.0019$ \\
\hline Intermittent $\left(0.43-0.53 \mathrm{~km}^{2}\right)$ & 2 x lower & \\
Small Perennial $\left(0.80-3.40 \mathrm{~km}^{2}\right)$ & 4 x lower & \\
Medium Perennial $\left(10.1-31.9 \mathrm{~km}^{2}\right)$ & 150 x lower & \\
Large Perennial $\left(41.8-164.4 \mathrm{~km}^{2}\right)$ & 653 x lower & \\
\hline & Intermittent & $0.0001-0.0011$ \\
\hline Ephemeral $\left(0.16-0.18 \mathrm{~km}^{2}\right)$ & $2 \times$ higher & \\
Small Perennial $\left(0.80-3.40 \mathrm{~km}^{2}\right)$ & 2 x lower & \\
Medium Perennial $\left(10.1-31.9 \mathrm{~km}^{2}\right)$ & 66 x lower & \\
Large Perennial $\left(41.8-164.4 \mathrm{~km}^{2}\right)$ & 288 x lower & \\
\hline & Small Perennial & $0.0000-0.0047$ \\
\hline Ephemeral $\left(0.16-0.18 \mathrm{~km}^{2}\right)$ & $4 \times$ higher & \\
Intermittent $\left(0.43-0.53 \mathrm{~km}^{2}\right)$ & $2 \times$ higher & \\
Medium Perennial $\left(10.1-31.9 \mathrm{~km}^{2}\right)$ & $35 \times$ lower & \\
Large Perennial $\left(41.8-164.4 \mathrm{~km}^{2}\right)$ & 154 x lower & \\
\hline & Medium Perennial & $0.0000-0.0006$ \\
\hline Ephemeral $\left(0.16-0.18 \mathrm{~km}^{2}\right)$ & $150 \times$ higher & \\
Intermittent $\left(0.43-0.53 \mathrm{~km}^{2}\right)$ & 66 x higher & \\
Small Perennial $\left(0.80-3.40 \mathrm{~km}^{2}\right)$ & $35 \times$ higher & \\
Large Perennial $\left(41.8-164.4 \mathrm{~km}^{2}\right)$ & $4 \times$ lower & \\
\hline & Large Perennial & $0.0001-0.0007$ \\
\hline Ephemeral $\left(0.16-0.18 \mathrm{~km}^{2}\right)$ & $653 \times$ higher & \\
Intermittent $\left(0.43-0.53 \mathrm{~km}^{2}\right)$ & $288 \times$ higher & \\
Small Perennial $\left(0.80-3.40 \mathrm{~km}^{2}\right)$ & $154 \times$ higher & \\
Medium Perennial $\left(10.1-31.9 \mathrm{~km}^{2}\right)$ & $4 \times$ higher & \\
\hline & &
\end{tabular}


Table 17: Processing ability units (PAUs) as compared to ephemeral and intermittent channel average processing ability. A small perennial stream with low processing ability (PA) is $1 / 11^{\text {th }}$ that of the average ephemeral channel and for every 100 PAUs from an ephemeral cannel, there are 9 PAUs from a low PA small perennial stream. If a low PA stream can be restored to a high PA stream, 27 PAUs will be gained.

\begin{tabular}{llll}
\hline & $\begin{array}{l}\text { Processing } \\
\text { ability }\end{array}$ & $\begin{array}{l}\text { Fraction of ephemeral } \\
\text { PA }\end{array}$ & PAU \\
\hline Low PA & 0.0001 & $1 / 11$ & \\
Moderate PA & 0.0003 & $3 / 11$ & 9 \\
High PA & 0.0004 & $4 / 11$ & 27 \\
& Processing & Fraction of intermittent & PAU \\
& ability & PA & \\
\hline Low PA & 0.0001 & $1 / 5$ & 20 \\
Moderate PA & 0.0003 & $1 / 1.67$ & 60 \\
High PA & 0.0004 & $4 / 5$ & 80 \\
\hline
\end{tabular}




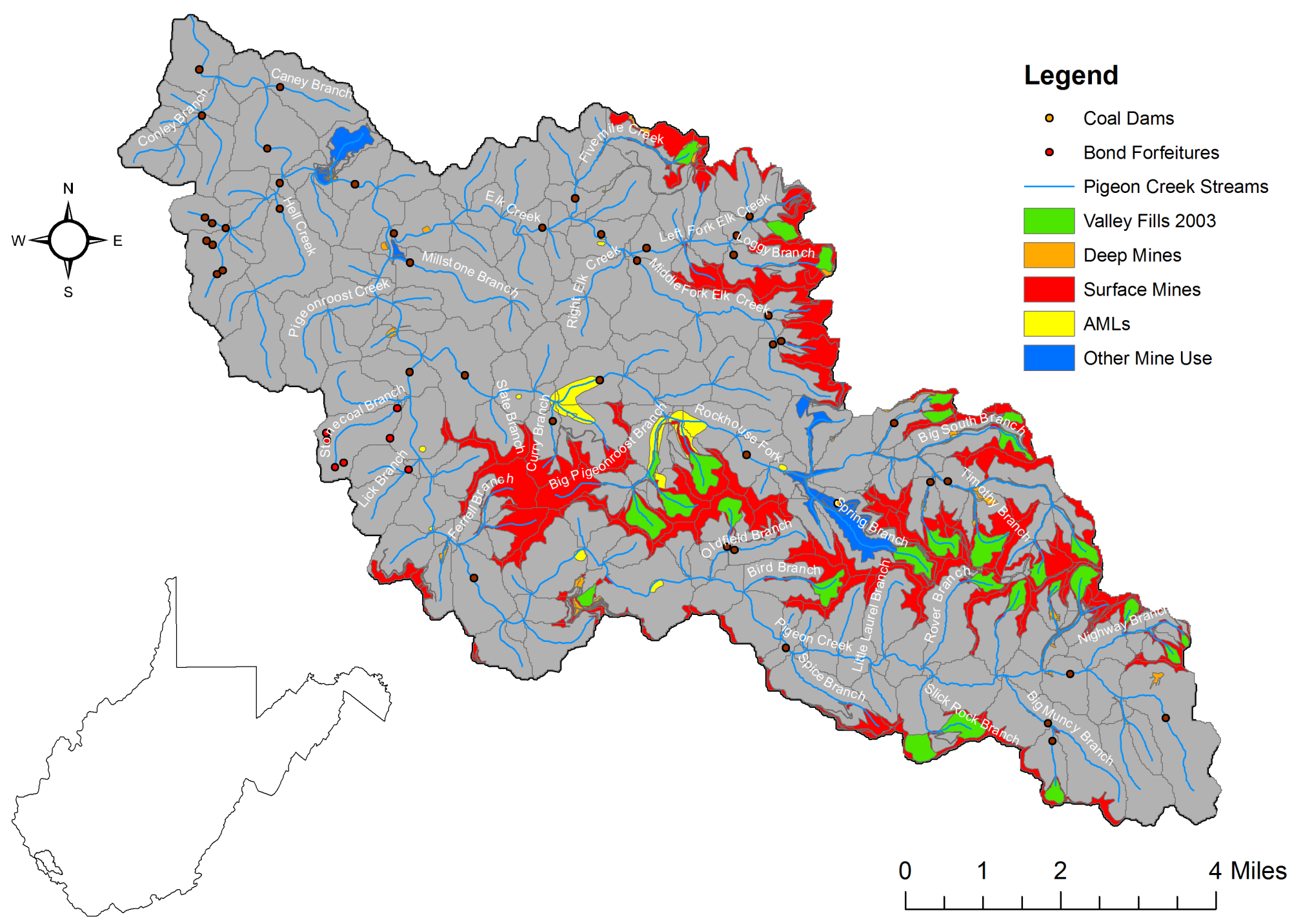

Figure 1: Distribution of mining throughout the Pigeon Creek watershed 


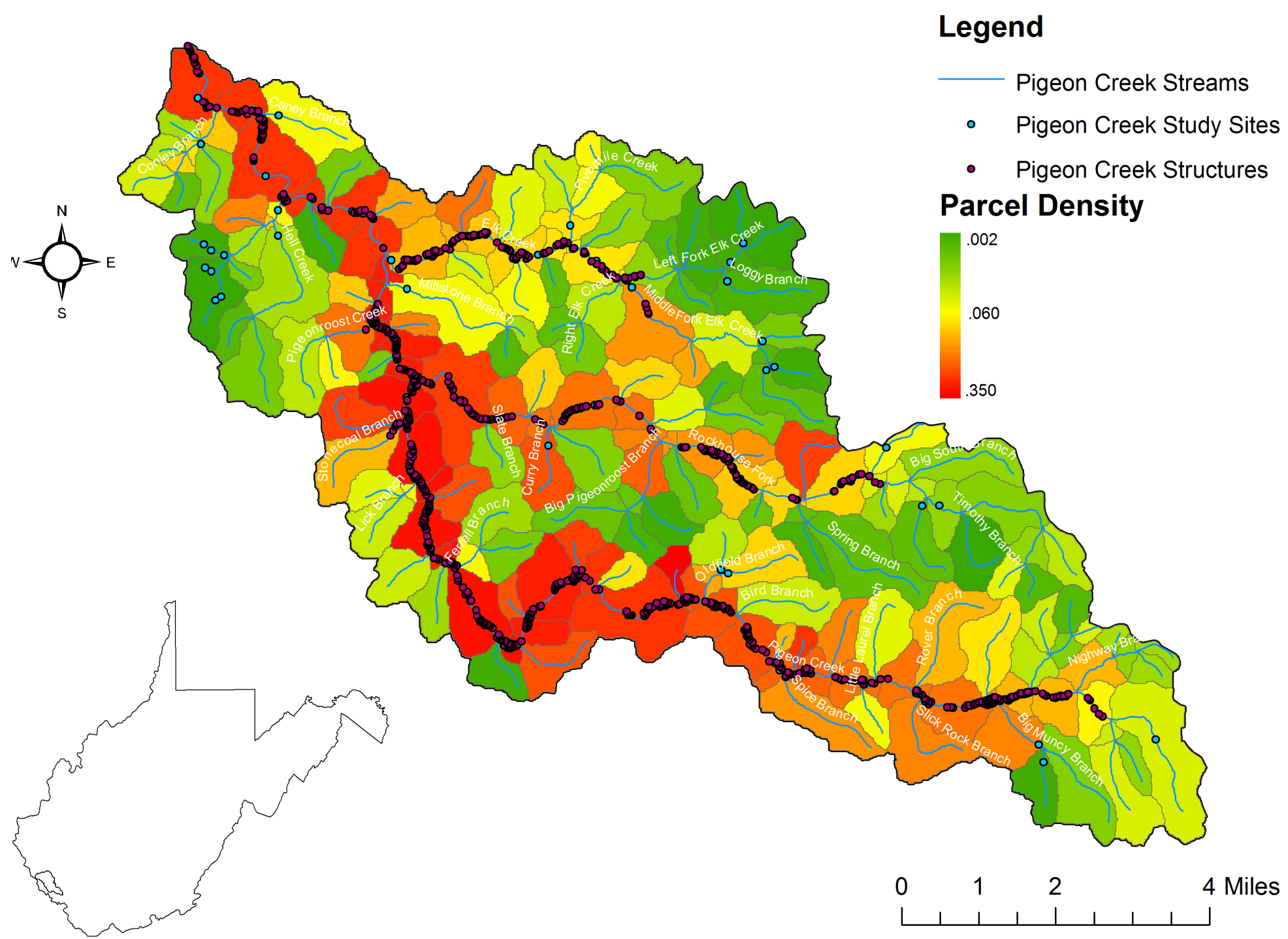

Figure 2: Parcel density in the Pigeon Creek watershed 


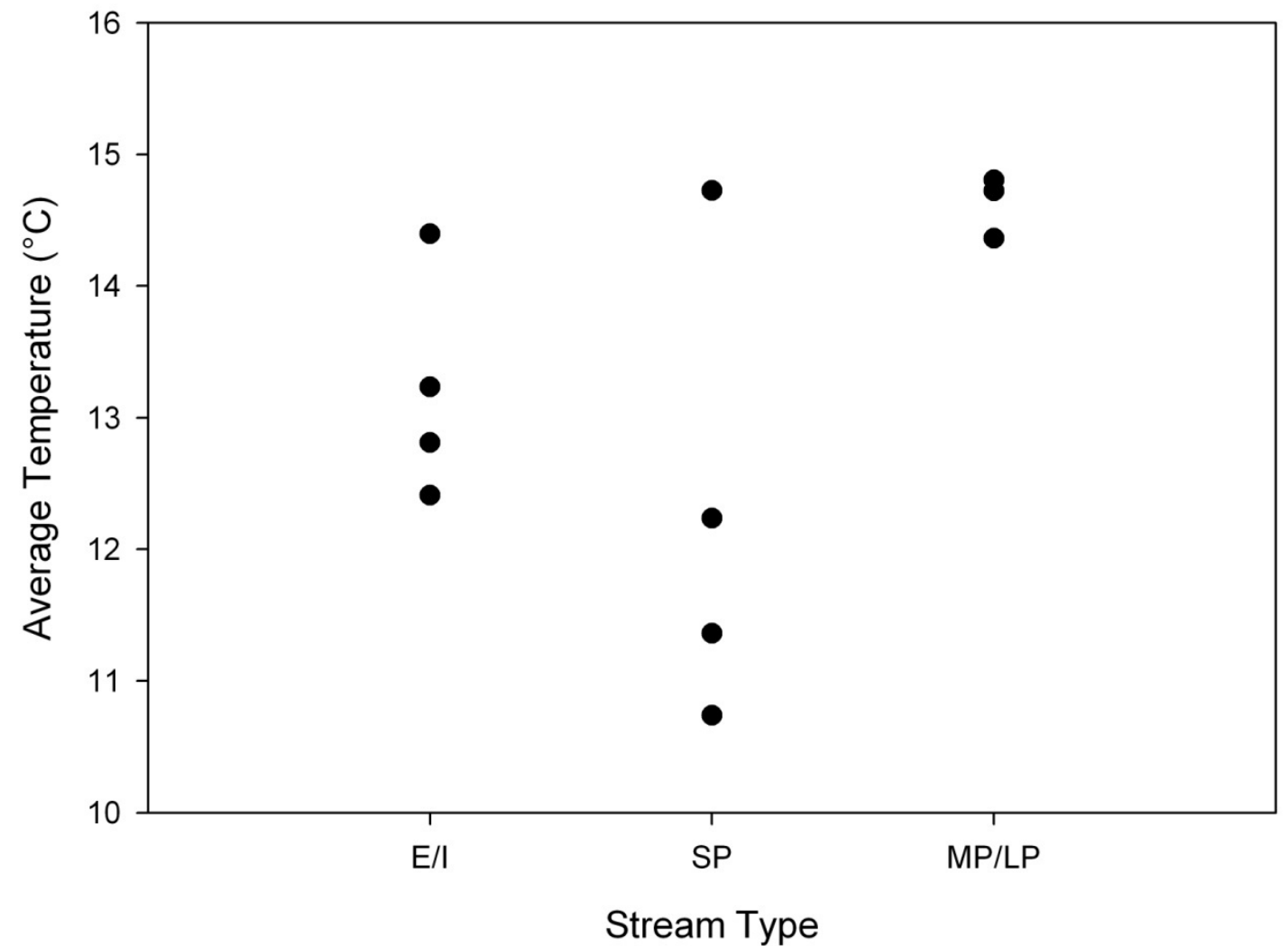

Figure 3: Range of measured temperature values across different basin area types [E/I: ephemeral/intermittent (0.16-0.53 km²), SP: small perennial $\left(0.80-3.40 \mathrm{~km}^{2}\right)$, MP/LP: medium perennial/large perennial (10.1-164.4 $\left.\left.\mathrm{km}^{2}\right)\right]$. Temperature was recorded continuously throughout the study period; values shown are averages. 


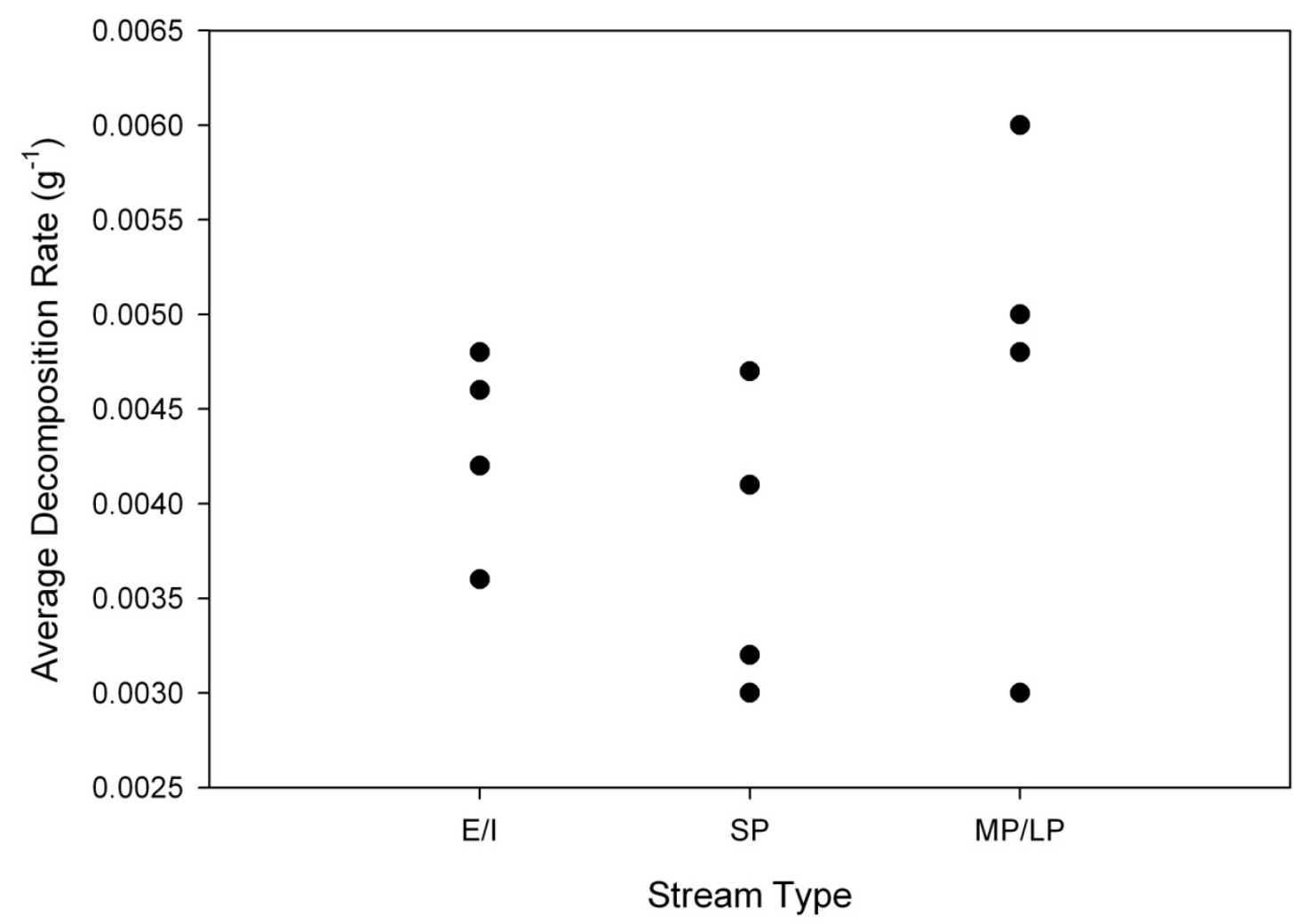

Figure 4: Range of measured decomposition values across stream types [E/I: ephemeral/intermittent (0.16-0.53 $\left.\mathrm{km}^{2}\right)$, SP: small perennial $\left(0.80-3.40 \mathrm{~km}^{2}\right)$, MP/LP: medium perennial/large perennial (10.1-164.4 $\left.\left.\mathrm{km}^{2}\right)\right]$. Decomposition values were not significantly different across stream types. 


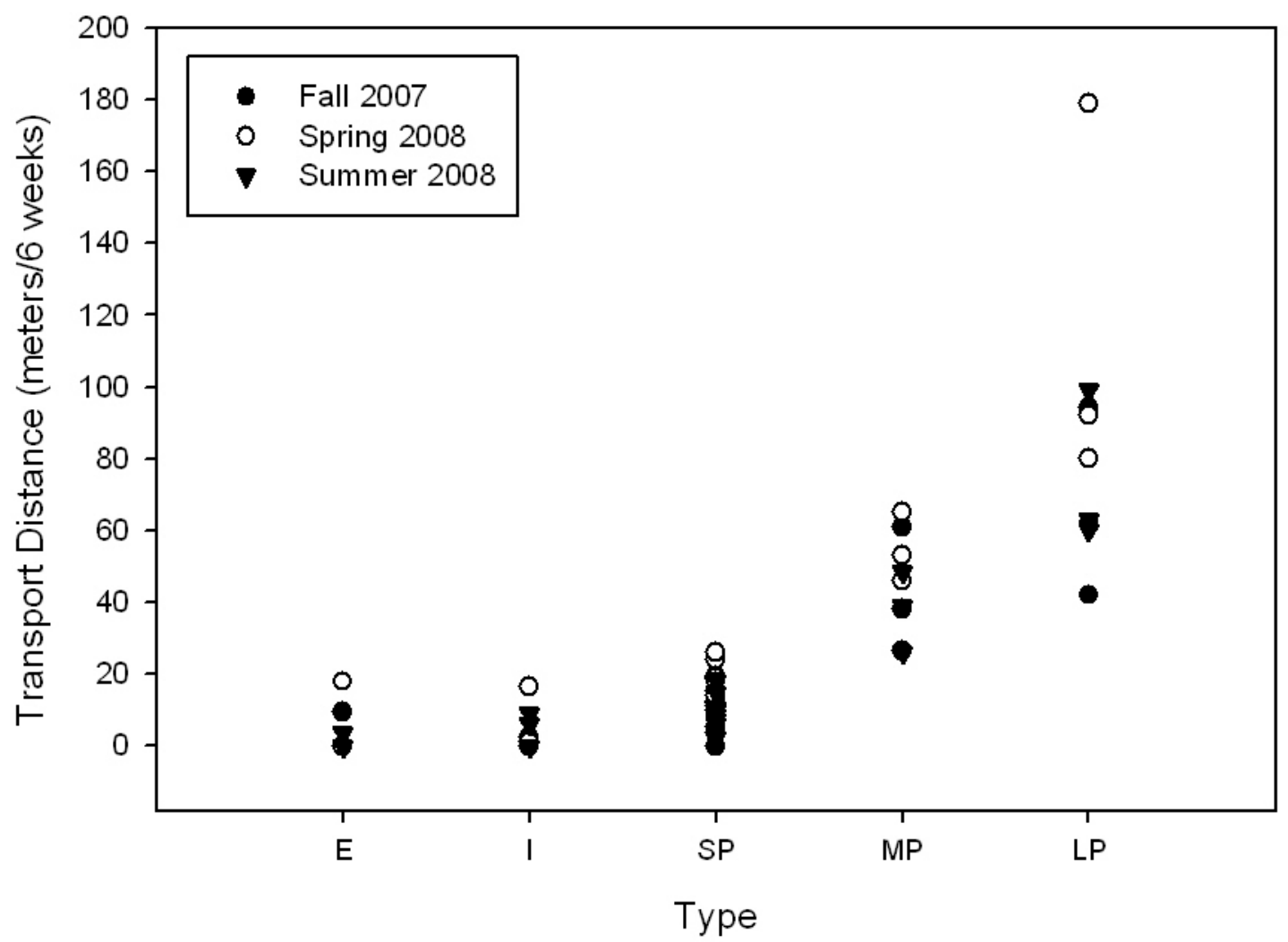

Figure 5: Relationship between seasonal dowel transport distance and drainage area in the 3 seasons that organic matter transport was measured. Dowel transport distance increases exponentially with basin area. [E: ephemeral $\left(0.16-0.18 \mathrm{~km}^{2}\right.$ ], I: intermittent (0.43-0.53 $\left.\mathrm{km}^{2}\right)$, SP: small perennial $\left(0.80-3.40 \mathrm{~km}^{2}\right)$, MP: medium perennial (10.1-31.9 km²), LP: large perennial (41.8-164.4 $\left.\left.\mathrm{km}^{2}\right)\right]$ 


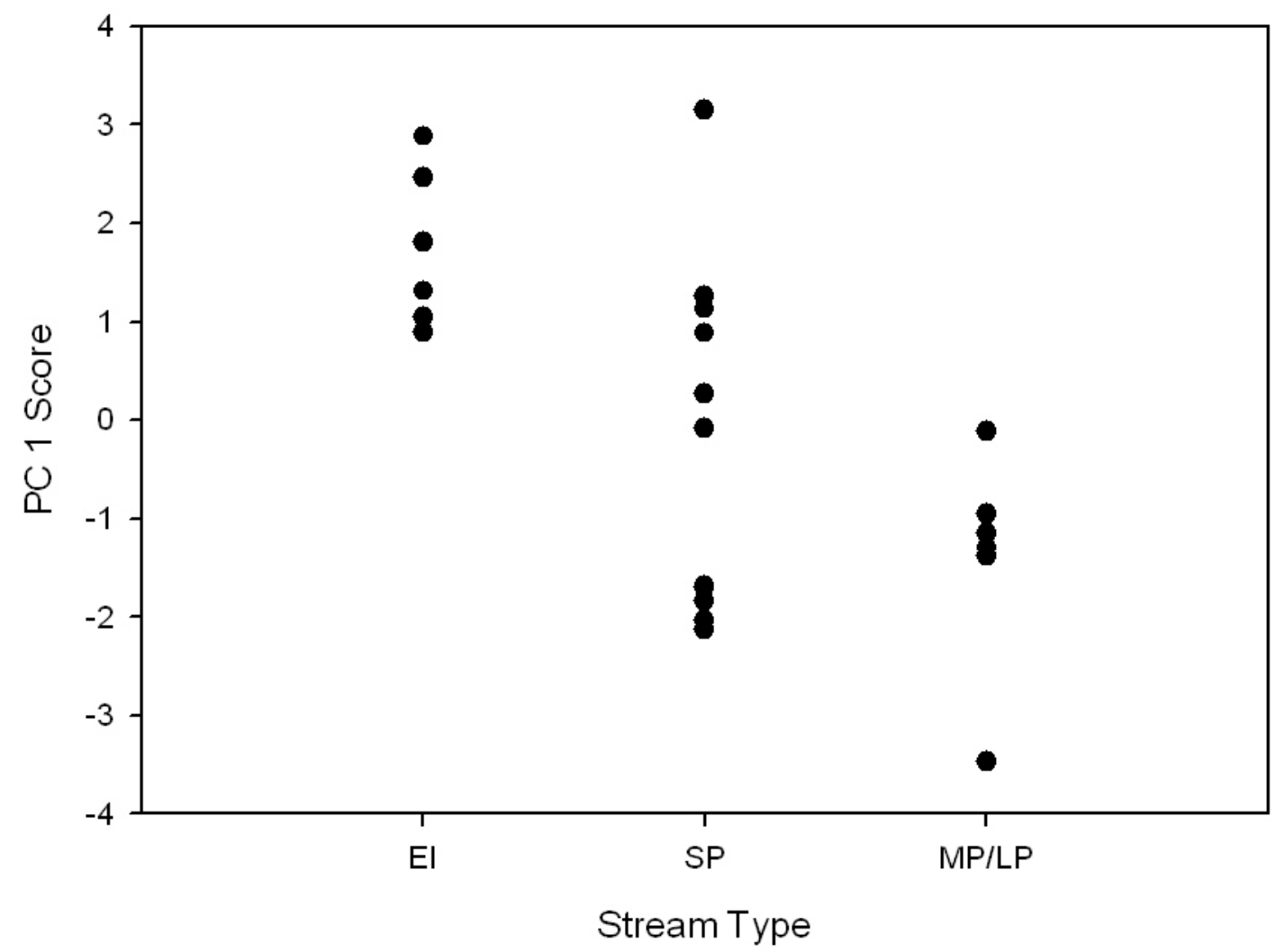

Figure 6: Distribution of Principle Component 1 scores (structural complexity measures) over grouped stream type. The higher the PC 1 score, the more structurally complex the site is [E: ephemeral $\left(0.16-0.18 \mathrm{~km}^{2}\right)$, I: intermittent $(0.43-$ $\left.0.53 \mathrm{~km}^{2}\right)$, SP: small perennial $\left(0.80-3.40 \mathrm{~km}^{2}\right)$, MP: medium perennial (10.1-31.9 $\mathrm{km}^{2}$ ), LP: large perennial (41.8-164.4 $\left.\left.\mathrm{km}^{2}\right)\right]$. Small perennial sites exhibited the widest range of habitat conditions. 


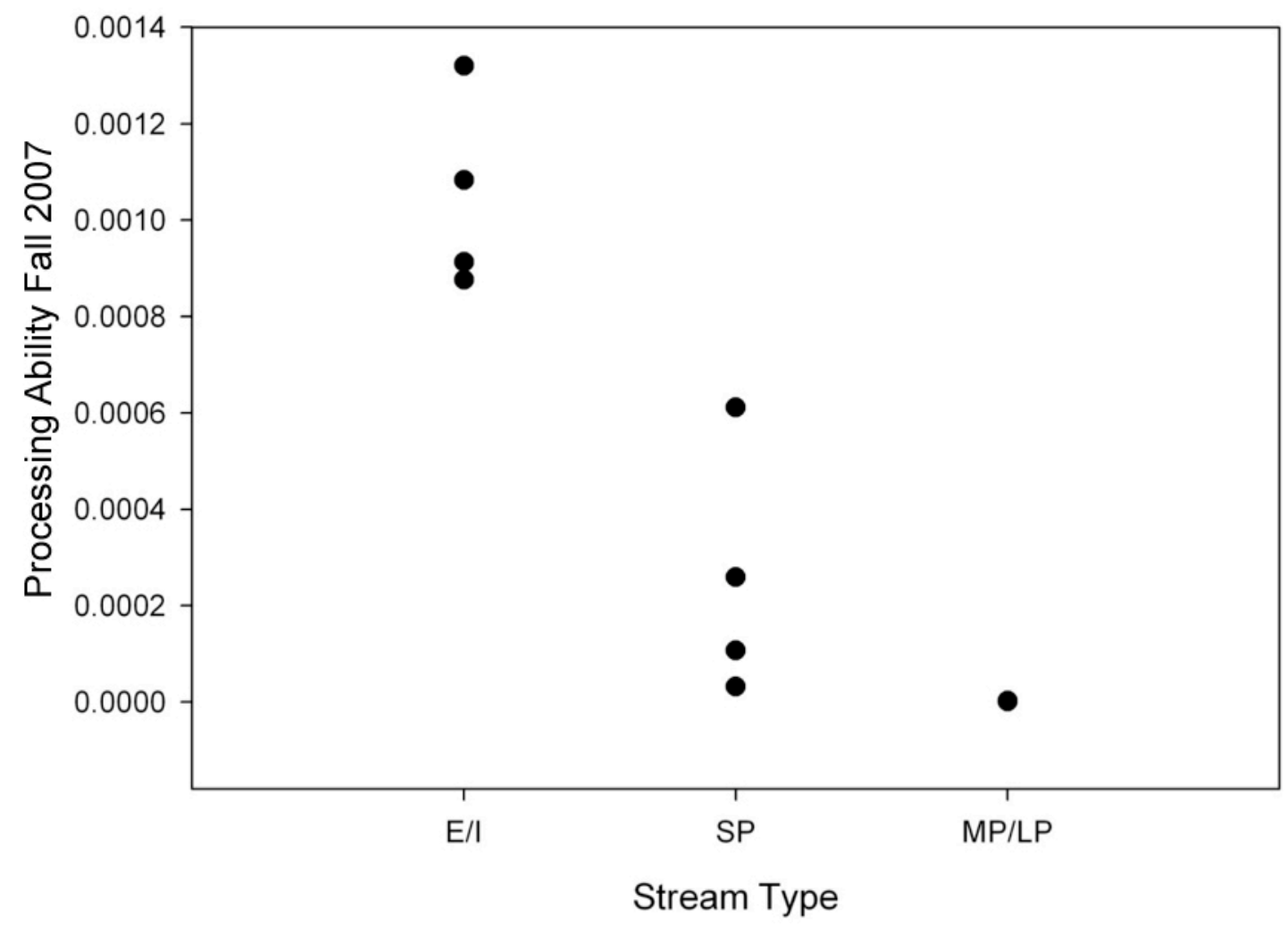

Figure 7: Processing ability in Fall 2007 for each group of stream types. Processing ability was highest in ephemeral/intermittent sites and lowest in medium and large perennial sites [E/I: ephemeral/intermittent (0.16-0.53 km²), SP: small perennial (0.80-3.40 $\left.\mathrm{km}^{2}\right), \mathrm{MP} / \mathrm{LP}$ : medium perennial/large perennial $\left.\left(10.1-164.4 \mathrm{~km}^{2}\right)\right]$. 


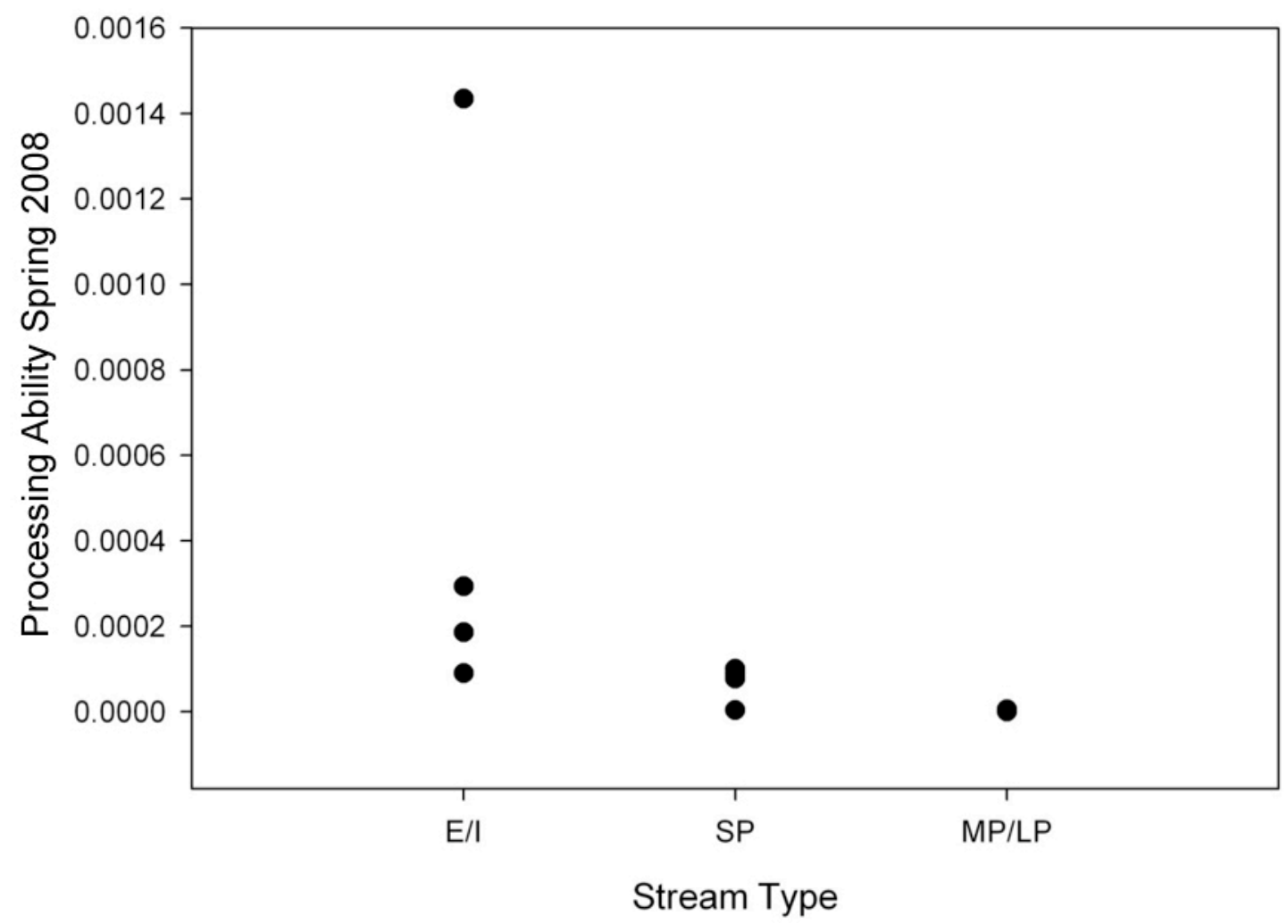

Figure 8: Processing ability in Spring 2008 for each group of stream types [E/I: ephemeral/intermittent (0.16-0.53 $\left.\mathrm{km}^{2}\right)$, SP: small perennial $\left(0.80-3.40 \mathrm{~km}^{2}\right)$, MP/LP: medium perennial/large perennial (10.1-164.4 $\left.\left.\mathrm{km}^{2}\right)\right]$. 


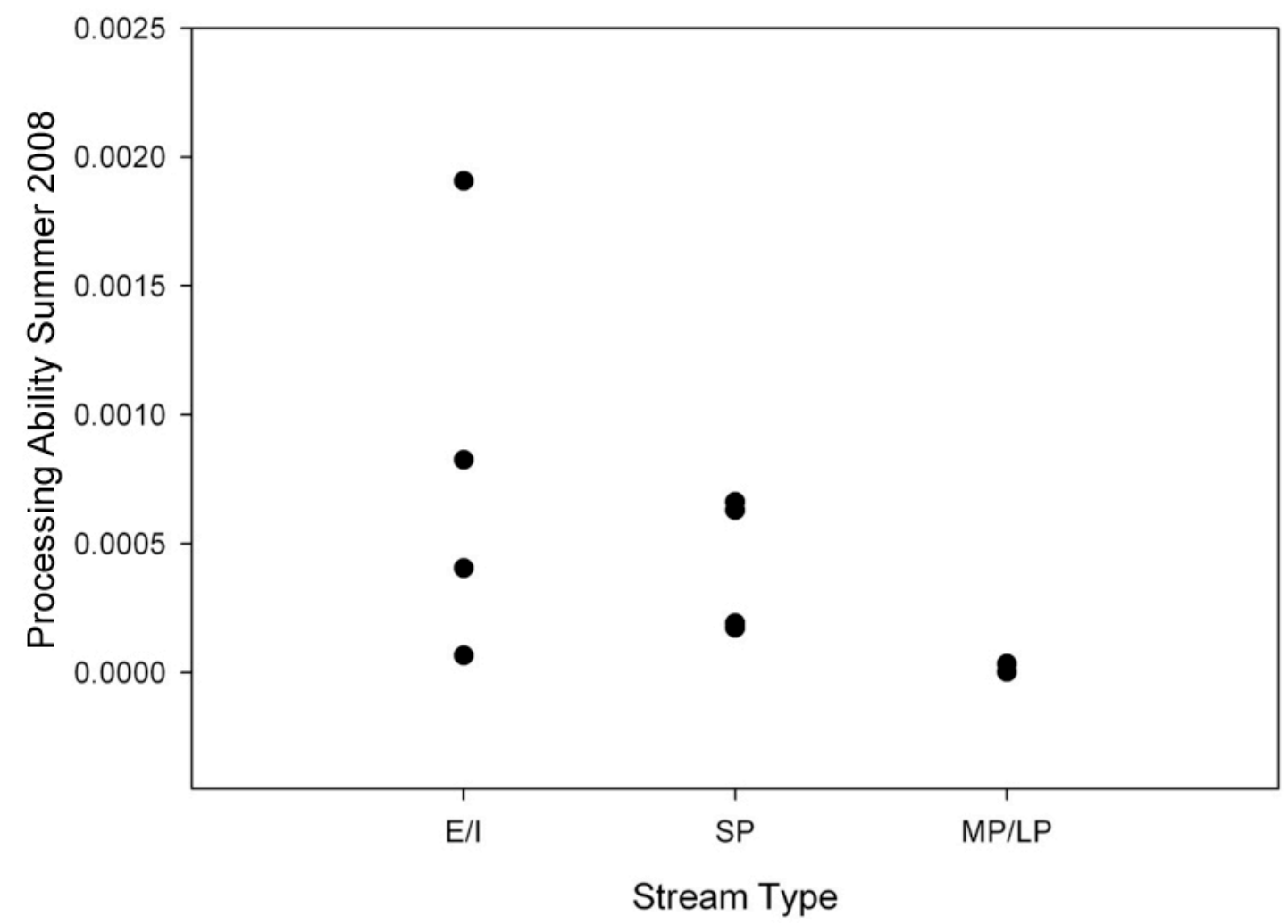

Figure 9: Processing ability in Summer 2008 for each group of stream types [E/I: ephemeral/intermittent (0.16-0.53 $\left.\mathrm{km}^{2}\right)$, SP: small perennial $\left(0.80-3.40 \mathrm{~km}^{2}\right)$, MP/LP: medium perennial/large perennial (10.1-164.4 $\left.\left.\mathrm{km}^{2}\right)\right]$. 


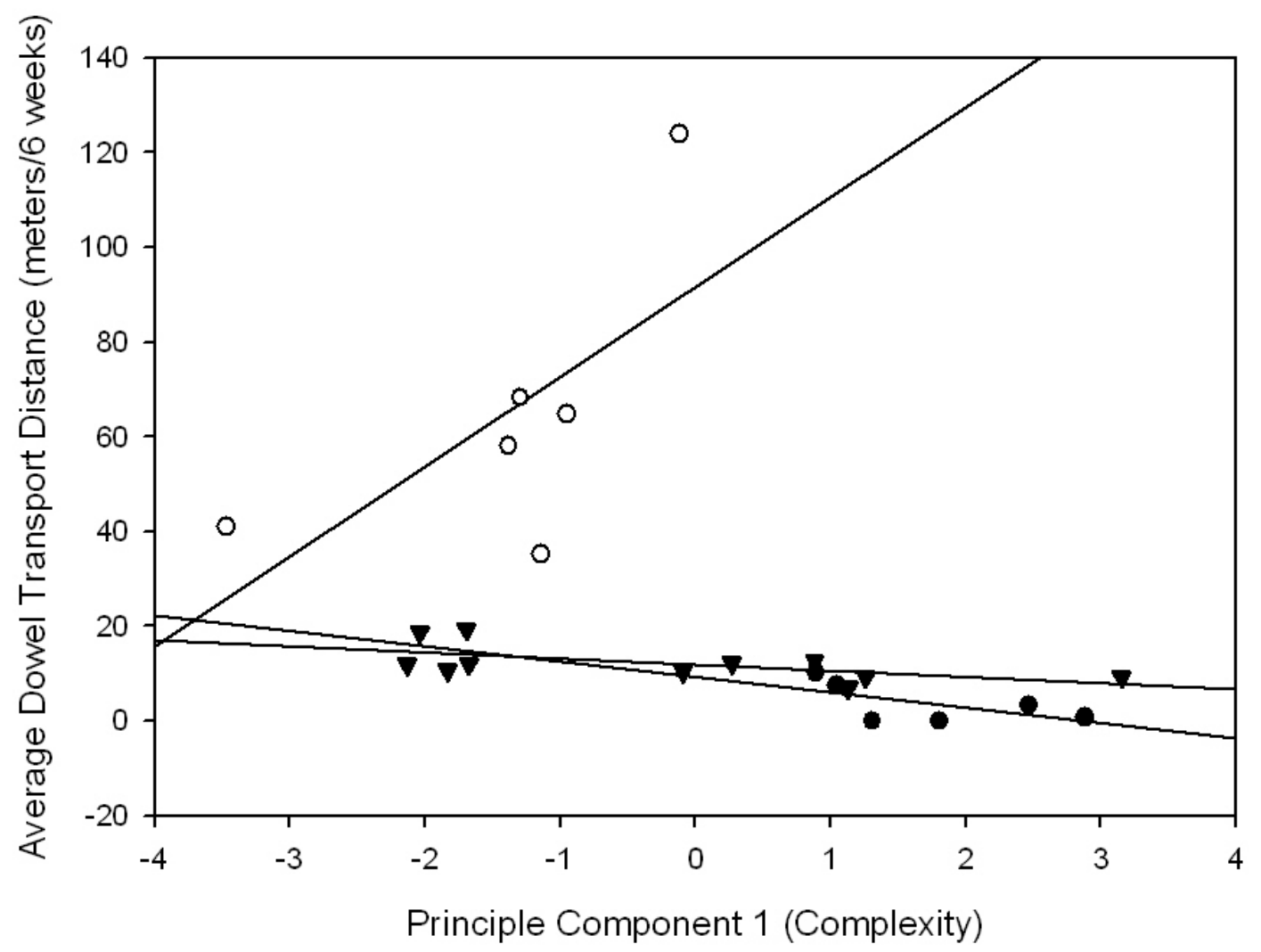

- Ephemeral/Intermittent $\left(r^{2}=0.36\right)$

- Medium and Large Perennial $\left(r^{2}=0.45\right)$

- Small Perennial $\left(r^{2}=0.34\right)$

Figure 10: Principle Component 1 Score (complexity measures) and dowel transport distance averaged across all seasons. Dowel transport distance tended to decline with increasing structural complexity in ephemeral/intermittent sites and small perennial sites. However, increasing structural complexity increased dowels transport distance in medium and large perennial sites. 


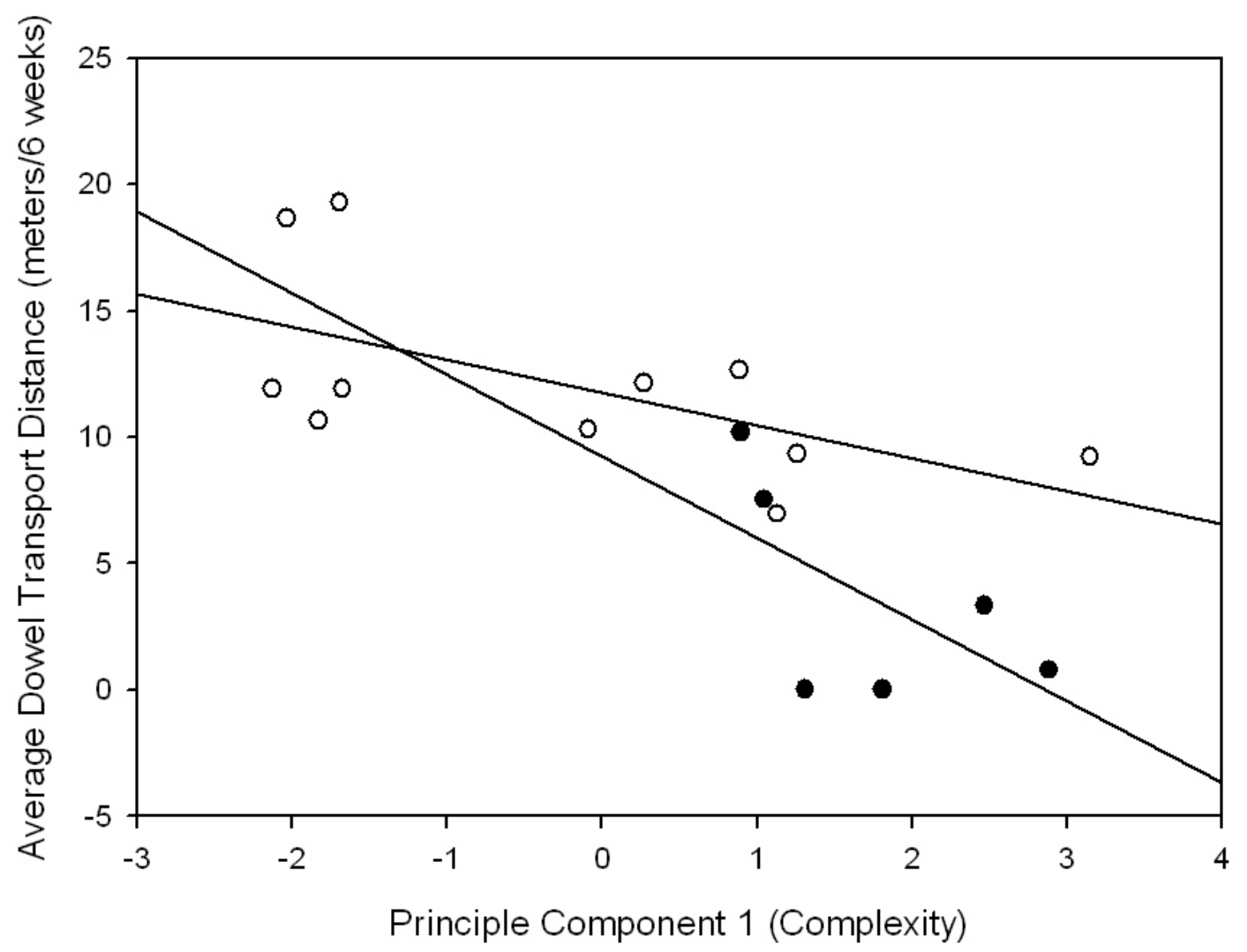

- Ephemeral/Intermittent $\left(r^{2}=0.36\right)$

- Small Perennial $\left(r^{2}=0.36\right)$

Figure 11: Principle Component 1 Score (complexity measures) and dowel transport distance averaged across all seasons. For Principle Component 1, the higher the score, the more complex the site is. There is a slight negative relationship between PC 1 and average dowel transport distance. 


\section{Stream flow, water chemistry, and organic matter processing downstream of headwater valley fills in an intensively mined Appalachian watershed}

\section{Introduction}

The ephemeral, intermittent, and first order perennial streams are generally accepted as making up a watershed's headwaters (Richardson and Danehy 2007). These streams can contain up to $80 \%$ of a watershed's stream length (Meyer 2001) and are very important as local habitats for macroinvertebrates, plants, and small vertebrates. Headwaters are tightly integrated with the land surrounding them and have a high edge to surface area ratio (Gomi et al. 2002). These streams receive a large amount of nutrient inputs from the surrounding land in the form of organic matter and terrestrial invertebrates. Because they are vulnerable to low flows (Swanson et al. 1998), headwaters also usually lack predatory species of fish. Oftentimes, the top-level predators in headwater streams are salamanders and predatory macroinvertebrates. This makes headwaters important habitats for many species of invertebrates, especially shredders and collector-gatherers (Haggerty et al. 2002). Although primary production in headwaters is low because of high canopy cover (Kiffney et al. 2004), headwaters still provide important habitat for many species of mosses and liverworts. These plants provide cover for small fish and invertebrates and provide case-building materials for species of caddisfly. 
Headwaters are especially important in supplying nutrients to downstream ecosystems (Vannote et al. 1980; Wipfli and Gregovich 2002). They are highly retentive (Brookshire and Dwire 2003; Hassan 2005) and receive the bulk of the organic matter inputs entering the system. Organic matter that falls into streams can be transported downstream, broken down, or retained in the channel. Organic matter breakdown and transport has been well studied (Vannote et al. 1980; Webster and Benfield 1986; Webster et al. 1994; Wallace et al. 1995; Benfield 1996; Gessner et al. 1999; Webster et al. 1999; Hieber and Gessner 2002 ,etc.), and there exists a good general knowledge of how this process works. Organic matter provides food, carbon, nitrogen, and many other essential nutrients to the stream (Petersen and Cummins 1974; Vannote et al. 1980; Wallace et al. 1997; Wallace et al. 1999; Webster et al. 1999).

Since small streams are so important, activities disrupting these streams may have large and far-reaching effects on the entire watershed. One of these activities, mountaintop removal mining (MTR mining) directly affects headwater catchments. The practice involves removing the soil and rock above and around coal deposits. This effectively removes the top of a mountain and the leftover fill is deposited in headwater valleys. This fill can cover hundreds of meters of stream channels within a drainage. The maximum size for valley fills is $1.9 \mathrm{~km}^{2}$ and that can encompass more than one drainage area (Paybins 2003). According to the US EPA (2005), valley fills buried approximately 1,165 km between 1985 and 2001. Mountaintop removal mining essentially results in the reconfiguration of headwater catchments. 
This may potentially have a considerable effect on downstream ecosystems through the loss of headwater function.

When filled, headwater streams cannot transport organic matter, and macroinvertebrate densities are often reduced in downstream areas (Hartman et al. 2005; Pond et al. 2008). Macroinvertebrates are very important in the processing of organic matter inputs. Grasses and herbaceous cover generally grow on the fill instead of the usual trees (United States Environmental Protection Agency 2005), reducing canopy cover and important organic matter input. Studies suggest that valley fills can increase flooding potential and have a large impact on flow and hydrology in headwater streams (Wiley et al. 2001; Phillips 2004; United States Environmental Protection Agency 2005). Hydrology and flow are important factors in many biological processes such as the transport and breakdown of organic matter (Hoover et al. 2006). Sedimentation may also be increased in sites below valley fills (Wiley and Brogan 2003). All of these accumulate into a large impact in a small headwater system.

Where knowledge is lacking is how to use a biological process like organic matter processing to assess stream health and set restoration priorities. Many studies have suggested that leaf breakdown is a sensitive and largely-encompassing measure of stream health (Pascoal et al. 2001). It can be an indicator of hydraulic conditions (Webster et al. 1994), macroinvertebrate and fungal activity (Webster and Benfield 1986; Hieber and Gessner 2002; Barnden and Harding 2005), and water chemistry (Suberkropp and Chauvet 1995; Dangles et al. 2004). Braioni et al. (2004) found that litter breakdown rates and measures of structural processes were 
complementary. In a low-diversity headwater stream this is especially promising. Some studies also suggest that combining traditional stream health measures such as water chemistry, habitat, flow, and community assemblages with biological data gives the best overall indicator of stream integrity (Pascoal et al. 2001).

However, the direct effects of land use on ecosystem processes such as organic matter are generally unknown across a broad range of settings. Studies have been conducted with varying results. Paul et al. (2006) found that leaves in urban and agricultural streams had faster breakdown rates than leaves in forested or suburban streams. We also know that traditional underground mining affects water chemistry, which in turn, has an effect on organic matter processing. Streams impacted by acid mine drainage can have reduced leaf breakdown rates (Carpenter et al. 1983; Mulholland et al. 1987; Niyogi et al. 2002; Barnden and Harding 2005). Some studies have found no variation in decomposition rates across different land use gradients (Sponseller and Benfield 2001; Huryn et al. 2002; Hagen et al. 2006). Few, if any, studies have measured the effects of large-scale surface mining on organic matter processing.

\section{Objectives}

The main objective of this study was to quantify the effects of valley fills on organic matter processing, flow variability, and structural complexity in small perennial streams. To accomplish this I compared organic matter processing rates in streams affected by valley fills to those of control sites. Leaf decomposition rates were measured as well as instantaneous and long-term retention. Each site was 
also scored for its' biotic and abiotic retentiveness and habitat quality. Finally, flow and temperature variability were continuously monitored at each site.

\section{Hypotheses (Figure 1):}

1. Flow regimes below valley fills will exhibit higher average flows and be less variable than those at control sites (Phillips 2004).

2. Seasonal patterns in organic matter transport will be altered below valley fills relative to control streams. Sites below valley fills will have longer transport distances in the late Summer and Fall because of augmented flow. In the Spring, however, control sites may have larger transport distances because of the occurrence of flashy flows.

3. Organic matter decomposition rates below valley fills are expected to be reduced, due to changes in water quality and reductions in macroinvertebrate densities. However, these effects may be offset by increased mechanical breakdown due to increased average flows in the valley fill sites.

\section{Study Area}

The study area for this project was in the headwaters of Pigeon Creek in Mingo County, West Virginia. Pigeon Creek is a subwatershed of the Tug Fork River in southern West Virginia. It has been intensively affected by surface mining for decades and continues to be mined presently (Figure 1, Chapter 2 above). 
The study design consisted of eight sites: four of which were below valley fills and four of which were control sites. The four control sites were also included in the basin area study above. These sites were all headwater sites with basin areas ranging from $0.80-1.09 \mathrm{~km}^{2}$. All of the sites were similar in terms of channel width and basin area (Table 1).

\section{Methods}

\section{Field Sampling}

\section{Physical and Chemical Characteristics}

Water quality, water temperature, water level, and physical habitat characteristics were measured at each site. These measurements help to quantify the effects of valley fills on flow variability and structural complexity. Water quality was measured three times: April 2007, November 2007, and April 2008. For this study, water quality included measuring conductivity $(\mu \mathrm{S} / \mathrm{cm})$ with a YSI $600 \mathrm{XL}$ Multi-Parameter Water Quality Monitor (YSI Incorporated, Yellow Springs, OH). Each site had a meter installed that measured water level variability and temperature (OnSet Corp) every ten minutes. Water level and temperature were recorded throughout the study from November 2007 to January 2009.

Habitat characteristics were measured at each site in Summer 2008. Measurements included: Rapid Visual Habitat Assessment (RVHA) (Barbour et al. 1999), Bank Erosion Hazard Index (BEHI) (Rosgen 2001), thalweg profile (Petty et al. 2001), and "retention scores." 
The thalweg profile is a habitat survey conducted along the thalweg of each site (Petty et al. 2001). It includes measures of depth, channel unit (riffle, run, pool, glide), distance to nearest fish cover, distance to nearest retentive feature, large woody debris count, pebble count (Wolman 1954), and gradient. Large woody debris were classified based on length and width (Petty et al. 2001). Fish cover was defined as any object within the active channel capable of concealing a $20-\mathrm{cm}$ fish. A retentive feature was any physical feature of the stream capable of retaining leaves at a bankfull flow. Gradient was measured to the nearest $0.1 \%$ using a clinometer. Points were spaced based on mean stream width. For stream widths greater than 5 meters, points were spaced every $1 / 2$ stream width. For widths less than 5 meters, points were spaced every stream width. The maximum distance measured was 300 meters and the minimum distance was 150 meters.

The "retention score" is a visual method for scoring a stream's structural retentiveness that we developed for this study (Appendix 1). It helps to link structural complexity to organic matter processing and quantify the effects of mining on physical habitat. It scores like an extra category for the RVHA protocol. Retentiveness is based on two separate parts of a stream's structure: inorganic retentiveness and organic retentiveness. After walking the entire stream reach, a stream is scored based on how well it will retain organic matter (small sticks and leaves). Scores are based on what would be ideal for that particular basin area. For example, a small headwater stream will be inherently more retentive than a $3^{\text {rd }}$ or $4^{\text {th }}$ order stream. The larger stream doesn't score lower than the headwater stream just based on size alone. If both streams were optimal for their size, they both 
would receive the same score. For the purpose of this habitat assessment, a stream is scored based on its inorganic retentiveness and its organic retentiveness. Inorganic retentive features include: boulders, undercut banks, a natural meander pattern, and side pools. Organic retentive features include: large woody debris (LWD), root wads, and overhanging limbs.

\section{Organic matter retention, decomposition, and processing ability}

Organic matter retention and decomposition were measured at each site for three different seasons to quantify how each headwater site processed organic matter (Table 2) (Lamberti 1996). Retention included instantaneous and long-term retention. Instantaneous retention was measured with pieces of construction paper cut into small artificial leaves $(10 \mathrm{~cm} \times 13 \mathrm{~cm})$. Artificial leaves were released at the top of a riffle allowed to float downstream for 30 minutes. After transport had stopped, the distance each leaf had traveled was measured and the object on which it was retained was recorded. For any leaf that exited the reach, the reach length was recorded as the distance traveled. For long-term retention, fifty individuallynumbered dowel rods were then released into the channel at the beginning of the same riffle that was used for the artificial leaves. The dowels were uniform size and shape: $18 \mathrm{~cm}$ long and $0.5 \mathrm{~cm}$ diameter. The dowels were spread uniformly across the channel and allowed to float downstream. After 30 minutes the distance each dowel had traveled and what it was retained on was recorded. For dowels that exited the reach, the reach length was recorded as the distance traveled. The dowels were left in the channel for six weeks and every two weeks the distance 
traveled was recorded. Using this data, the seasonal retention rate was calculated for each site. The retention rate is expressed as (Speaker 1984):

$$
T_{d}=T_{o} e^{-k d}
$$

$\mathrm{T}_{\mathrm{d}}$ is the percent of dowels that exited the reach at the end of the study period. $\mathrm{T}_{\mathrm{o}}$ is $100 \%$. The instantaneous retention rate is represented by $\mathrm{k}$. The reach length (here, 10x wetted width) is represented by $\mathrm{d}$.

Organic matter breakdown was also measured at all of the sites (Benfield 1996). Twelve leaf packs were placed in a riffle at each site and allowed to decompose for 75 and 120 days. The leaf packs consisted of 10 grams of pin oak leaves each in $1 \mathrm{~cm}$ mesh. The packs were secured with rope either to roots or rebar hammered into the streambed. Six packs were removed after 75 days and the remaining six were removed after 120 days. After removal, the packs were kept on ice for transport back to the lab. Once in the lab, leaves were rinsed of sediment over a $250 \mu \mathrm{m}$ sieve to preserve any macroinvertebrates. The macroinvertebrates were stored in 95\% ethanol for later identification to genus level and functional feeding group (Merritt 2008). After rinsing, the leaves from each site were placed in brown paper bags and allowed to air dry at room temperature for several days. Once dry, the leaves were crushed into a coarse powder. A muffle furnace was used to combust $250 \mathrm{mg}$ of the coarse powder from each site for 40 minutes (Benfield 1996). Ash-free dry mass (AFDM) was calculated using the following formula: \%Organic Matter=(DM $\left.\mathrm{Dample}_{\text {sample }}\right) / \mathrm{AM}_{\text {sample }} \mathrm{X} 100$ $\mathrm{AFDM}=\mathrm{DM} \times \mathrm{\% OM}$ $\%$ AFDM remaining= 100-((initial-final $) /$ initial $\times 100)$ 
(DM= dry mass; $\mathrm{AM}=$ ash mass; $\mathrm{OM}=$ organic matter)

\%AFDM remaining was then log-transformed and regressed against the days of exposure. The slope of the line is the K-value, or rate of decomposition (Benfield 1996).

Stream processing ability was also calculated based on organic matter retention and decomposition. Processing ability is defined as the relative ability of a stream to retain and process organic matter locally. It is a way to quantify how well a site can retain and subsequently break down organic matter entering it. The organic matter is incorporated into the local food web or is delivered downstream. The seasonal decomposition rate is multiplied by the seasonal retention rate to calculate a stream's season-specific processing ability.

\section{Statistical Methods}

Average artificial leaf and dowel rod transport distances were calculated for each site and each season. Averages across all seasons for each site were also calculated. Unless otherwise noted, "average transport" refers to transport distance averaged across all seasons. Decomposition rate was also calculated for each of three seasons.

Using the depth data from the thalweg profile, a coefficient of variation of depth at the thalweg for each site was calculated. This coefficient of variation of depth was used as another structural complexity variable. Using the temperature data, a coefficient of variation of temperature, average minimum, average maximum, average overall temperature, average daily range, maximum daily range, average 
daily coefficient of variation, and maximum daily coefficient of variation was calculated for each site. Also, the variables "average gradient”, "canopy cover" and "large woody debris per meter" were log-transformed.

Principle Components Analysis (PCA) was conducted using the following structural complexity measures: retentive score, number of retentive features per meter, large woody debris per meter, RVHA score, canopy cover, coefficient of variation of depth, and mean distance (meters) to retentive feature. The PCA results were then correlated with all of the structural complexity variables. Variables correlated with a principle component with a correlation coefficient greater than 0.5 were kept as part of that component.

Pairwise correlations were run between transport distance averaged across all seasons and the following structural complexity variables: large woody debris per meter, mean distance to retentive feature, retentive score, RVHA score, PC 1, number of retentive features per meter, average gradient, and coefficient of variation of depth.

T-tests were used to compare valley fill and control sites using the following variables: maximum daily coefficient of temperature, mean daily coefficient of variation of temperature, maximum daily temperature range, mean daily temperature range, average temperature, minimum temperature, maximum temperature, overall coefficient of variation of temperature, average conductivity, overall decomposition, decomposition for each season, processing ability, coefficient of variation of water level, and average depth. 
Using macroinvertebrate data collected from leaf packs, percent shredders, percent collector-gatherers, percent predators, and percent other were calculated. These variables were correlated with decomposition data to determine any relationship between decomposition rates and macroinvertebrates. Two-way ANOVA was used to determine the interacting effects of season and stream type (control or valley fill) on water level, temperature, water quality, organic matter transport and decomposition, and macroinvertebrate data.

Non-metric multidimensional scaling was performed to visualize how different all sites were in terms of functional feeding groups present (Clarke 1993). The sites were mapped in space with the R language and environment for statistical computing Version 2.8.1 (R Development Core Team 2009).

\section{Results}

\section{Structural Complexity, Transport Distance and Decomposition}

Principle Components Analysis grouped structural complexity measures into 2 significant axes: Principle Component 1 (PC 1) and Principle Component 2 (PC 2)

(Table 3). PC 1 includes measures of: retentive score, number of retentive features per meter, large woody debris per meter, RVHA score, coefficient of variation of depth, and mean distance (meters) to retentive feature. Principle Component 2 includes coefficient of variation of depth and RVHA score. Only principle component 1 was interpreted.

When valley fill and control sites were grouped together, coefficient of variation of depth was highly correlated with dowel transport distance (Table 4). 
No structural complexity variables were correlated with artificial leaf transport distance (leaf transport distance was generally low for all sites). For valley fill sites alone, coefficient of variation of depth and large woody debris per meter were correlated with dowel and artificial leaf transport distance, respectively (Table 5). For control sites, coefficient of variation of depth was correlated with transport distance (Table 6).

\section{Comparisons Between Valley Fill and Control Sites}

There was no significant difference between valley fills and non-valley fills in terms of decomposition (Tables 7 and 8), however valley fills had a larger range of values. This wider range of values was caused by high variation in decomposition rates at valley fill sites in Summer 2008 (Figure 2). Both valley fill and control sites had a range of water quality conditions (Table 9). There was also no significant difference between valley fills and control sites in terms of retention, however controls had a larger range of values (Figure 3). Valley fill sites also had a wider range of habitat conditions (Figure 4 and 5). Figures 4 and 5 show the range of Rapid Visual Habitat Assessment and Retentive scores for each site type. However, there was not a significant difference between control and valley fill sites in terms of retention score and RVHA. Although not statistically significant, water levels below valley fills tended to be less variable than those at control sites (Figures 6 and 7). Processing ability also did not differ between valley fill and control sites except for Fall 2007 (Table 7, Figure 8).

In two way ANOVAs, stream type did not have a significant effect on any of the variables tested. However, season had a significant effect on temperature, dowel 
and leaf transport distance, macroinvertebrate variables, and water quality. There was no significant interaction between season and type (Table 10).

NMDS results did not appear to show any grouping among the sites. A solution of 2 dimensions was reached after 19 runs with a stress of 7.60 (Figure 9).

\section{Discussion}

\section{Analysis of All Sites}

All of our headwater sites were highly variable in terms of decomposition and organic matter transport. This is not unexpected and follows the results from Chapter 2 above. Small headwater streams are highly variable. In the Appalachians, these streams have been known to support approximately 40 algal taxa (Greenwood and Rosemond 2005), over 50 species of fungi (Gulis and Suberkropp 2003), and numerous macroinvertebrate species (McCabe 2000).

\section{Differences Between Valley Fill and Control Sites}

We were surprised to not find a significant difference in flow regime between valley fill and control sites. Our valley fills sites did have a wider range of values. However, when water levels were looked at seasonally, there was a lot of variation (Figure 7). In Spring 2008, valley fills had a wider range of water levels than control sites. Perhaps when flows are very high in the Spring months, sediment ponds are less able to stabilize flows. While this did not have a significant effect on dowel transport distances or decomposition, it is possible that flow interacts with other factors that cancel out the effects that flow alone would have on organic matter processing. 
One of our valley fill sites (VF 1) was positioned above the sediment pond instead of below it. This valley fill was older than the other fills; this fill was approximately 20 years old whereas the others were approximately 10 years old. This site had a much higher coefficient of variation of water level than even our control sites (Table 9). Although no solid conclusions can be drawn from this single sample, the data suggest that sediment ponds do help in controlling the flashiness of the streams draining valley fills. Wiley and Brogan (2003) found that sites on streams impacted by valley fills had a wider range of flood recurrence intervals. This suggests that, not only are headwater streams highly variable, but also the valley fills themselves. Some valley fill sites can also have very similar streamflow to unimpacted sites (Wiley et al. 2001). The effects of valley fills on streamflow are highly dependent on how the fill and sediment pond were constructed. Messinger (2003) found that runoff from fills and streamflow is highly site-specific.

Artificial leaf and dowel transport did not differ significantly between valley fill and control sites. Organic matter transport may depend on structural complexity in small streams (Hoover et al. 2006). A concurrent study (Chapter 2 above) indicated that our small perennial sites had widely-varying habitat conditions. The inherent high variability of habitat conditions in this study may have masked any effects that valley fills had on habitat.

Transport distances were only measured once every two weeks. This was probably too spaced out for these small, flashy streams. Valley fill sites have a different flow regime (Phillips 2004) and may be moving the dowels in a different 
way. A flashy control site will push all of the dowels out after a rain event whereas a valley fill site may continuously move dowels for the entire period of time. After two, four, or six weeks the valley fill and control sites have moved the dowels the same distance but in potentially very different ways. Dalzell et al. (2007) found that high flow events in small streams were especially important in organic matter transport.

Decomposition did not differ significantly between valley fill and control sites, either. We expected to find a difference in decomposition rates and believe that valley fill sites decompose differently. However, the no difference may have been detected because of our low sample size. Although we expected decomposition to be higher in valley fill sites because of the differing flow regime, Simon et al. (2009) found that discharge did not significantly affect leaf breakdown. Sponseller and Benfield (2001) found that, at the watershed scale, decomposition was not significantly related to land cover. However, our study was on a much smaller scale and only included sites that were similar to each other in terms of drainage area and channel width. Hagen et al. (2006) and Bird and Kaushik (1992) found that leaf breakdown rates were not a good indicator of stream health across a land-use gradient. Our study also was not conducted along a gradient. Our study is unique in that it directly compares streams below valley fills to control sites.

It is less surprising that valley fill and control sites did not differ in terms of decomposition when the fact that water quality did not differ significantly between sites is taken into consideration. Though not significant, there was a slight positive relationship between leaf breakdown and conductivity (Figure 10). Leaves break 
down faster in higher temperatures (Webster and Benfield 1986). Conductivity and water quality also has an effect on leaf breakdown (Simon et al. 2009). Simon et al. (2009) found that there was no difference in leaf breakdown at sites located above and below acid mine drainage treatment stations. This study was conducted at a similar scale to ours. These results suggest that it may be difficult to determine any differences in organic matter processing at a fine scale because of the high variability of small streams. Also, our macroinvertebrate assemblages from leaf packs did not differ among site types.

In terms of decomposition, it is possible that valley fills sites are more "sterile". In order for leaves to break down, a leaf needs to first be conditioned by fungi and bacteria, and then macroinvertebrates take over in breaking the leaf down (Webster and Benfield 1986). Fungal and bacterial assemblages were not measured in this study, so there is no way to know if these differed between valley fill and control sites. Streams draining control sites were mostly forested and streams draining valley fills drained a more barren area. Control sites may have much more opportunity for fungal and bacterial colonization than valley fill sites. If leaves in control sites were better colonized then this could potentially cancel out the effect of the higher flows in valley fill sites. In other words, valley fill sites have the potential for higher decomposition rates, but this potential is possibly negated by the fact that these streams drain a relatively sterile landscape. Several studies have linked a reduction in macroinvertebrate, bacterial, and fungal communities to a reduction rate of decomposition (Mulholland et al. 1987; Niyogi et al. 2001; Dangles et al. 2004; Simon et al. 2009). 
Since there was no difference in organic matter transport and breakdown between site types, the fact that processing ability did not differ is not surprising. In Figure 1, we expected valley fill sites to have higher decomposition rates because we expected them to be wetter. But, we also expected control sites to retain organic matter better. The combination of the better retention of the control sites and the better breakdown of the valley fill sites may have cancelled each other out. However, we found no differences in breakdown and retention.

\section{Final Conclusions/Management Implications}

This study shows that seasonal and stream-to-stream variation may override any effects that valley fills have on organic matter processing. Although no statistically significant differences could be found between valley fill and control sites, the noticeable difference in flow may indicate that there are underlying, interacting factors that affect organic matter processing in these sites. These subtle effects are difficult to tease apart. Since headwater streams are inherently highly variable, it's hard to separate the variability due to land use from the inherent variability.

A larger study with a larger sample size may be better able to tease apart the effects of valley fills from natural stream variability. Also, our control sites were highly variable in their condition. Some of our control sites were still impacted by old roads or nearby houses. In this watershed, it is very difficult to find streams that are completely untouched and the variation in condition among control sites is just a matter of fact. This study suggests that proper construction of a valley fill and sediment pond are very important in controlling the flow in a stream below a fill. 
Also, the effects of valley fills on biological processes are highly variable and more study is needed.

\section{Works Cited}

Allan, J. D. 1995. Stream ecology, 1st edition. Chapman and Hill, Philadelphia.

Barbour, M. T., J. Gerritsen, B. D. Snyder, and J. B. Stribling. 1999. Rapid bioassessment protocols for use in streams and wadeable rivers: Periphyton, benthic macroinvertebrates and fish, second edition. Epa 841-b-99-002. U.S. Environmental Protection Agency; Office of Water; Washington, D.C.

Barnden, A. R., and J. S. Harding. 2005. Shredders and leaf breakdown in streams polluted by coal mining in the south island, new zealand. New Zealand Natural Sciences 30:35-48.

Benfield, E. F. 1996. Leaf breakdown in stream ecosystems. Pages 579-590 in F. R. Hauer, and G. A. Lamberti, editors. Methods in stream ecology. Academic Press, New York.

Benfield, E. F., J. R. Webster, J. J. Hutchens, J. L. Tank, and P. A. Turner. 2000. Organic matter dynamics along a stream-order and elevational gradient in a southern appalachian stream. Verhandlungen der Internationalen Vereinigung für theoretische und angewandte Limnologie 27:1341-1345.

Bird, G. A., and N. K. Kaushik. 1992. Invertebrate colonization and processing of maple leaf litter in a forested and an agricultural reach of a stream. Hydrobiologia 234(2):65-77.

Braioni, M. G., M. D. Cortivo, and G. Salmoiraghi. 2004. Leaf litter breakdown processing in the functional monitoring of a mountain stream. International Review of Hydrobiology 89(5-6):536-550.

Brookshire, E. N. J., and K. A. Dwire. 2003. Controls on patterns of coarse organic particle retention in headwater streams. Journal of the North American Benthological Society 22(1):17-34.

Carpenter, J., W. E. Odum, and A. Mills. 1983. Leaf litter decomposition in a reservoir affected by acid mine drainage. Oikos 41(2):165-172.

Clarke, K. R. 1993. Non-parametric multivariate analyses of changes in community structure. Austral Ecology 18(1):117-143. 
Cummins, K. W., and coauthors. 1980. Processing of confined and naturally entrained leaf litter in a woodland stream ecosystem. Limnology and Oceanography 25(5):952-957.

Dalzell, B. J., T. R. Filley, and J. M. Harbor. 2007. The role of hydrology in annual organic carbon loads and terrestrial organic matter export from a midwestern agricultural watershed. Geochimica et Cosmochimica Acta 71(6):1448-1462.

Dangles, O., M. O. Gessner, F. Guerold, and E. Chauvet. 2004. Impacts of stream acidification on litter breakdown: Implications for assessing ecosystem functioning. Journal of Applied Ecology 41(2):365-378.

Ehrman, T. P., and G. A. Lamberti. 1992. Hydraulic and particulate matter retention in a 3rd-order indiana stream. Journal of the North American Benthological Society 11(4):341-349.

ESRI. 2006. Arcgis version 9.2 and the spatial analyst extension. Environmental Systems Research Institute, Redlands, CA.

Fisher, S. G., N. B. Grimm, E. Martí, R. M. Holmes, and J. J. B. Jones. 1998. Material spiraling in stream corridors: A telescoping ecosystem model. Ecosystems 1(1):19-34.

Fritz, K. M., Johnson, Brent R., Walters, David M. 2008. Physical indicators of hydrologic permanence in forested headwater stream. Journal of the North American Benthological Society 27(3):690-704.

Gessner, M. O., E. Chauvet, and M. Dobson. 1999. A perspective on leaf litter breakdown in streams. Oikos 85(2):377-384.

Gomi, T., R. C. Sidle, and J. S. Richardson. 2002. Understanding processes and downstream linkages of headwater systems. BioScience 52:905-916.

Greenwood, J. L., and A. D. Rosemond. 2005. Periphyton response to long-term nutrient enrichment in a shaded headwater stream. Canadian Journal of Fisheries \& Aquatic Sciences 62(9):2033-2045.

Gulis, V., and K. Suberkropp. 2003. Leaf litter decomposition and microbial activity in nutrient-enriched and unaltered reaches of a headwater stream. Freshwater Biology 48(1):123-134.

Hagen, E. M., J. R. Webster, and E. F. Benfield. 2006. Are leaf breakdown rates a useful measure of stream integrity along an agricultural landuse gradient? Journal of the North American Benthological Society 25(2):330-343.

Haggerty, S. M., D. P. Batzer, and C. R. Jackson. 2002. Macroinvertebrate assemblages 
in perennial headwater streams of the coastal mountain range of washington, u.S.A. Hydrobiologia 479(1):143-154.

Hartman, K. J., M. D. Kaller, J. W. Howell, and J. A. Sweka. 2005. How much do valley fills influence headwater streams? Hydrobiologia 532(1):91-102.

Hassan, M. A., Hogan, D. L., Bird, S. A., May, C. L., Gomi, T., Campbell, D. 2005. Spatial and temporal dynamics of wood in headwater streams of the pacific northwest. Journal of the American Water Resources Association 41(4):899919.

Hieber, M., and M. O. Gessner. 2002. Contribution of stream detrivores, fungi, and bacteria to leaf breakdown based on biomass estimates. Ecology 83(4):10261038.

Hoover, T. M., J. S. Richardson, and N. Yonemitsu. 2006. Flow-substrate interactions create and mediate leaf litter resource patches in streams. Freshwater Biology 51(3):435-447.

Huryn, A. D., V. M. Butz Huryn, C. J. Arbuckle, and L. Tsomides. 2002. Catchment land-use, macroinvertebrates and detritus processing in headwater streams: Taxonomic richness versus function. Freshwater Biology 47(3):401-415.

Jones, J. B., Jr., and L. A. Smock. 1991. Transport and retention of particulate organic matter in two low-gradient headwater streams. Journal of the North American Benthological Society 10(2):115-126.

Kiffney, P. M., J. S. Richardson, and J. P. Bull. 2004. Establishing light as a causal mechanism structuring stream communities in response to experimental manipulation of riparian buffer width. Journal of the North American Benthological Society 23(3):542-555.

Kobayashi, S., and T. Kagaya. 2005. Hot spots of leaf breakdown within a headwater stream reach: Comparing breakdown rates among litter patch types with different macroinvertebrate assemblages. Freshwater Biology 50(6):921929.

Lamberti, G. A., Gregory, S. V. 1996. Transport and retention of cpom. F. R. Hauer, and G. A. Lamberti, editors. Methods in stream ecology. Academic Press, New York.

Latterell, J. J., Bechtold, J. S., O'Keefe, T. C., Pelt, R., Naiman, R. J. 2006. Dynamic patch mosaics and channel movement in an unconfined river valley of the olympic mountains. Freshwater Biology 51(3):523-544.

Lepori, F., D. Palm, and B. Malmqvist. 2005. Effects of stream restoration on ecosystem functioning: Detritus retentiveness and decomposition. Journal of 
Applied Ecology 42(2):228-238.

McCabe, D. J., Sykora, J. L. . 2000. Community structure of caddisflies along a temperate springbrook. Archiv Fur Hydrobiologie 148(2):263-282.

Merricks, C., D. Cherry, C. Zipper. 2003. Evaluation of hollow fill drainages and associated settling ponds on water quality and benthic macroinvertebrate communities of va and wv. In: 2003 Powell River Project Research and Education Reports.

Merritt, R. W., Cummins, K. W., Berg, M. B. 2008. An introduction to the aquatic insects of north america, 4th edition. Kendall Hunt Publishing.

Messinger, T. 2003. Comparison of storm response of streams in small, unmined and valley-filled watersheds, 1999-2001, ballard fork, west virginia. Charleston, WV.

Meyer, J. L., Wallace, J. B. 2001. Lost linkages and lotic ecology: Rediscovering small streams. Pages 295-316 in M. C. Press, Huntly, N. J., Levin, S. , editor. Ecology: Achievement and challenge. Blackwell, Oxford, U.K.

Millington, C. E., and D. A. Sear. 2007. Impacts of river restoration on small-wood dynamics in a low-gradient headwater stream. Earth Surface Processes and Landforms 32(8):1204-1218.

Minshall, G. W., and coauthors. 1983. Interbiome comparison of stream ecosystem dynamics. Ecological Monographs 53(1):2-25.

Mulholland, P. J., A. V. Palumbo, J. W. Elwood, and A. D. Rosemond. 1987. Effects of acidification on leaf decomposition in streams. Journal of the North American Benthological Society 6(3):147-158.

Naiman, R. J., J. M. Melillo, M. A. Lock, T. E. Ford, and S. R. Reice. 1987. Longitudinal patterns of ecosystem processes and community structure in a subarctic river continuum. Ecology 68(5):1139-1156.

Niyogi, D. K., W. M. Lewis, and D. M. McKnight. 2001. Litter breadown in mountain streams affected by mine drainage: Biotic mediation of abiotic controls. Ecological Applications 11(2):506-516.

Niyogi, D. K., D. M. McKnight, and W. M. Lewis. 2002. Effects of mine drainage on breakdown of aspen litter in mountain streams. Water, Air, \& Soil Pollution: Focus 2(2):329-341.

Pascoal, C., F. Cassio, and P. Gomes. 2001. Leaf litter processing and invertebrates leaf breakdown rates: A measure of water quality? International Review of Hydrobiology 86(4-5):407-416. 
Paul, M. J., Meyer, J. L., Couch, C. A. 2006. Leaf breakdown in streams differing in catchment land use. Freshwater Biology 51(9):1684-1695.

Paybins, K. S. 2003. Flow origin, drainage area, and hydrologic characteristics for headwater streams in the mountaintop coal-mining region of southern west virginia, 2000-01. Charleston, WV.

Petersen, R. C., and K. W. Cummins. 1974. Leaf processing in a woodland stream. Freshwater Biology 4:343-368.

Petty, J., Freund, J., Lamothe, P., Mazik, P. 2001. Quantifying instream habitat in the upper shavers fork basin at multiple spatial scales. Proceedings of the Southeastern Association of Fish and Wildlife Agencies 55:81-94.

Phillips, J. 2004. Impacts of surface mine valley fills on headwater floods in eastern kentucky. Environmental Geology 45:367-380.

Pond, G. J., M. E. Passmore, F. A. Borsuk, L. Reynolds, and C. J. Rose. 2008. Downstream effects of mountaintop coal mining: Comparing biological conditions using family- and genus-level macroinvertebrate bioassessment tools. Journal of the North American Benthological Society 27(3):717-737.

R Development Core Team. 2009. R: A language and environment for statistical computing. R Foundation for Statistical Computing Vienna, Austria.

Richardson, J. S., and R. J. Danehy. 2007. A synthesis of the ecology of headwater streams and their riparian zones in temperate forests. Forest Science 53:131147.

Riis, T., Sand-Jensen, K. 2006. Dispersal of plant fragments in small streams. Freshwater Biology 51(2):274-286.

Rosgen, D. 2001. A practical method of computing streambank erosion rate. Pages 18-26 in Proceedings of the Seventh Federal Interagency Sedimentation Conference, Reno, NV.

Simon, K. S., M. A. Simon, and E. F. Benfield. 2009. Variation in ecosystem function in appalachian streams along an acidity gradient. Ecological Applications 19(5):1147-1160.

Slonecker, E. T., Benger, M.J. 2001. Remote sensing and mountaintop mining. Remote Sensing Reviews 20(4):293-322.

Speaker, R., Moore, K., Gregory, S. 1984. Analysis of the process of retention of organic matter in stream ecosystems. Verhandlung Internationale Vereinigung Limnologie 22:1835-1841. 
Sponseller, R. A., and E. F. Benfield. 2001. Influences of land use on leaf breakdown in southern appalachian headwater streams: A multiple-scale analysis. Journal of the North American Benthological Society 20(1):44-59.

Strager, M. P., J. T. Petty, J. M. Strager, and J. Barker-Fulton. 2009. A spatially explicit framework for quantifying downstream hydrologic conditions. Journal of Environmental Management 90(5):1854-1861.

Suberkropp, K., and E. Chauvet. 1995. Regulation of leaf breakdown by fungi in streams: Influences of water chemistry. Ecology 76(5):1433-1445.

Swanson, F. J., S. L. Johnson, S. V. Gregory, and S. A. Acker. 1998. Flood disturbance in a forested mountain landscape. BioScience 48(9):681-689.

United States Environmental Protection Agency. 2005. Mountaintop mining/valley fills in appalachia final programmatic environmental impact statement.

Vannote, R. L., G. W. Minshall, K. W. Cummins, J. R. Sedell, and C. E. Cushing. 1980. The river contiuum concept. Canadian Journal of Fisheries and Aquatic Sciences 37(1):130-137.

Wallace, J. B., S. L. Eggert, J. L. Meyer, and J. R. Webster. 1997. Multiple trophic levels of a forest stream linked to terrestrial litter inputs. Science 277(5322):102104.

Wallace, J. B., S. L. Eggert, J. L. Meyer, and J. R. Webster. 1999. Effects of resource limitation on a detrital-based ecosystem. Ecological Monographs 69(4):409442.

Wallace, J. B., J. R. Webster, and T. F. Cuffney. 1982. Stream detritus dynamics: Regulation by invertebrate consumers. Oecologia 53(2):197-200.

Wallace, J. B., and coauthors. 1995. Long-term dynamics of coarse particulate organic matter in three appalachian mountain streams. Journal of the North American Benthological Society 14(2):217-232.

Webster, J. R., and E. F. Benfield. 1986. Vascular plant breakdown in freshwater ecosystems. Annual Review of Ecology and Systematics 17(1):567-594.

Webster, J. R., and coauthors. 1999. What happens to allochthonous material that falls into streams? A synthesis of new and published information from coweeta. Freshwater Biology 41(4):687-705.

Webster, J. R., A. P. Covich, J. L. Tank, and T. V. Crockett. 1994. Retention of coarse organic particles in streams in the southern appalachian mountains. Journal of the North American Benthological Society 13(2):140-150. 
Wigington, P. J., and coauthors. 2006. Coho salmon dependence on intermittent streams. Frontiers in Ecology and the Environment 4(10):513-518.

Wiley, J. B., and F. D. Brogan. 2003. Comparison of peak discharges among sites with and without valley fills for the july 8-9, 2001, flood in the headwaters of clear fork, coal river basin, mountaintop coal-mining region, southern west virginia. U.S. Department of the Interior, editor. U.S. Geological Survey.

Wiley, J. B., R. D. Evaldi, J. H. Eychaner, and D. B. Chambers. 2001. Reconnaissance of stream geomorphology, low streamflow, and stream temperature in the mountaintop coal-mining region, southern west virginia, 1999-2000, US Geological Survey Water-Resources Investigations Report 01-4092.

Wipfli, M. S. 2005. Trophic linkages between headwater forests and downstream fish habitats: Implications for forest and fish management. Landscape and Urban Planning 72(1-3):205-213.

Wipfli, M. S., and D. P. Gregovich. 2002. Export of invertebrates and detritus from fishless headwater streams in southeastern alaska: Implications for downstream salmonid production. Freshwater Biology 47(5):957-969.

Wolman, M. G. 1954. A method of sampling coarse river-bed material. Trans. Am. Geophys. Union 35:951-956. 
Table 1: Descriptions of valley fill (VF) and control (C) sites. Sites were selected to be similar in terms of basin area.

\begin{tabular}{lcccc}
\hline Site & $\begin{array}{c}\text { Basin Area } \\
\left(\mathrm{km}^{2}\right)\end{array}$ & $\begin{array}{c}\text { Gradient } \\
\text { (\% slope) }\end{array}$ & $\begin{array}{c}\text { Channel } \\
\text { Width } \\
\text { (meters) }\end{array}$ & $\begin{array}{c}\text { Percent } \\
\text { Canopy } \\
\text { Cover }\end{array}$ \\
\hline C1 & 0.98 & 2.3 & 2.2 & 87 \\
C2 & 0.80 & 2.5 & 3 & 85 \\
C3 & 1.09 & 2.6 & 1 & 90 \\
C4 & 0.86 & 6 & 3.1 & 77 \\
VF1 & 0.98 & 3.3 & 2 & 84 \\
VF2 & 0.99 & 4 & 1.5 & 69 \\
VF3 & 0.84 & 6 & 3.2 & 88 \\
VF4 & 0.91 & 3.75 & 2 & 86 \\
\hline
\end{tabular}


Table 2: Dates for organic matter variables measured.

\begin{tabular}{lcc}
\hline & $\begin{array}{c}\text { Organic Matter } \\
\text { Transport }\end{array}$ & $\begin{array}{c}\text { Organic Matter } \\
\text { Decomposition }\end{array}$ \\
\hline Fall 2007 & $11 / 18 / 07-12 / 30 / 07$ & $11 / 18 / 07-3 / 23 / 08$ \\
Spring 2008 & $3 / 23 / 08-5 / 3 / 08$ & $3 / 23 / 08-7 / 23 / 08$ \\
Summer 2008 & $7 / 23 / 08-9 / 10 / 08$ & $7 / 23 / 08-11 / 6 / 08$ \\
\hline
\end{tabular}


Table 3: Principle components analysis (PCA) results. A dot (.) means a variable is not included in a particular component. PCA was used to group habitat variables into one variable that could be used for "structural complexity." PC 1 was used to represent structural complexity.

\begin{tabular}{lcc}
\hline & PC 1 & PC 2 \\
\hline Eigenvalue & 3.34 & 1.21 \\
Total Variance Explained & 55.65 & 75.77 \\
Total Retentive Score & +0.9140 &. \\
Number of Retentive Features per Meter & +0.8103 &. \\
Large Woody Debris per Meter & +0.7917 &. \\
Rapid Visual Habitat Assessment & +0.7372 & -0.5602 \\
Coefficient of Variation of Depth & +0.5135 & +0.7946 \\
Mean Distance to Retentive Feature & -0.6426 &. \\
\hline
\end{tabular}


Table 4: Correlations between structural complexity variables as predictors and dowel transport distance (meters/6 weeks) and artificial leaf transport distance (meters/30 mins). In these correlations, valley fill and control sites were grouped. There was not one good predictor of organic matter transport in valley fill and control sites.

\begin{tabular}{lccc}
\hline Predictor & Corr & $\mathrm{n}$ & $\mathrm{p}$-value \\
\hline Dowels & & & \\
Retentive Score & -0.2908 & 8 & 0.4847 \\
RVHA & -0.3896 & 8 & 0.3401 \\
Average Gradient & -0.2832 & 8 & 0.4967 \\
LWD per meter & -0.3598 & 8 & 0.3814 \\
Coefficient of Variation of Depth & -0.8262 & 8 & 0.0115 \\
Retentive Features per meter & -0.1123 & 8 & 0.7911 \\
Mean distance to retentive feature (meters) & 0.3526 & 8 & 0.3917 \\
Principle Component 1 & -0.3504 & 8 & 0.3948 \\
Leaves & & & \\
Retentive Score & 0.0714 & 8 & 0.8667 \\
RVHA & 0.0001 & 8 & 0.9998 \\
Average Gradient & -0.3699 & 8 & 0.3670 \\
LWD per meter & -0.2964 & 8 & 0.4759 \\
Coefficient of Variation of Depth & -0.3705 & 8 & 0.3662 \\
Retentive Features per meter & -0.0219 & 8 & 0.9590 \\
Mean distance to retentive feature (meters) & -0.2597 & 8 & 0.5345 \\
Principle Component 1 & -0.0650 & 8 & 0.8784 \\
\hline
\end{tabular}


Table 5: Correlations between dowel transport distance (meters/6 weeks) and structural complexity variables for valley fill sites. For dowels, the best predictor of transport distance was coefficient of variation (CV) of depth. However, CV depth was not a good predictor for artificial leaf transport distance.

\begin{tabular}{lccc}
\hline Predictor & Corr & $\mathrm{n}$ & $\mathrm{p}$-value \\
\hline Dowels & & & \\
Retentive Score & -0.4374 & 4 & 0.5626 \\
RVHA & -0.5768 & 4 & 0.4232 \\
Average Gradient & -0.6815 & 4 & 0.3185 \\
LWD per meter & -0.1789 & 4 & 0.8211 \\
Coefficient of Variation of Depth & -0.9228 & 4 & 0.0772 \\
Retentive Features per meter & -0.1768 & 4 & 0.8232 \\
Mean distance to retentive feature (meters) & 0.6037 & 4 & 0.3963 \\
Principle Component 1 & -0.4117 & 4 & 0.5883 \\
Leaves & & & \\
Retentive Score & 0.7140 & 4 & 0.2860 \\
RVHA & 0.5077 & 4 & 0.4923 \\
Average Gradient & -0.2321 & 4 & 0.7679 \\
LWD per meter & 0.8843 & 4 & 0.1157 \\
Coefficient of Variation of Depth & -0.1139 & 4 & 0.8861 \\
Retentive Features per meter & 0.7859 & 4 & 0.2141 \\
Mean distance to retentive feature (meters) & -0.7633 & 4 & 0.2367 \\
Principle Component 1 & 0.7527 & 4 & 0.2473 \\
\hline
\end{tabular}


Table 6: Correlations between structural complexity variables and dowel transport distance (meters $/ 6$ weeks) in control sites. Coefficient of variation of depth was a good predictor of transport distance for both dowels and artificial leaves.

\begin{tabular}{lccc}
\hline Predictor & Corr & $\mathrm{n}$ & $\mathrm{p}$-value \\
\hline Dowels & & & \\
Retentive Score & -0.0438 & 4 & 0.9562 \\
RVHA & -0.1204 & 4 & 0.8796 \\
Average Gradient & -0.1353 & 4 & 0.8647 \\
LWD per meter & -0.5658 & 4 & 0.0334 \\
Coefficient of Variation of Depth & -0.8088 & 4 & 0.1912 \\
Retentive Features per meter & -0.0738 & 4 & 0.9262 \\
Mean distance to retentive feature (meters) & -0.0337 & 4 & 0.9663 \\
Principle Component 1 & -0.3506 & 4 & 0.6494 \\
Leaves & & & \\
Retentive Score & -0.0740 & 4 & 0.9260 \\
RVHA & -0.6148 & 4 & 0.3852 \\
Average Gradient & -0.3091 & 4 & 0.6909 \\
LWD per meter & -0.6487 & 4 & 0.3513 \\
Coefficient of Variation of Depth & -0.9652 & 4 & 0.0348 \\
Retentive Features per meter & -0.4809 & 4 & 0.5191 \\
Mean distance to retentive feature (meters) & -0.2743 & 4 & 0.7257 \\
Principle Component 1 & -0.5421 & 4 & 0.4579 \\
\hline
\end{tabular}


Table 7: Decomposition and processing ability values for each site

\begin{tabular}{|c|c|c|c|c|c|c|c|c|}
\hline Site & $\begin{array}{c}\text { Average } \\
\text { Decomposition } \\
\left(\mathrm{g}^{-1}\right)\end{array}$ & $\begin{array}{c}\text { Decomposition } \\
\text { Fall } 07 \\
\left(\mathrm{~g}^{-1}\right)\end{array}$ & $\begin{array}{c}\text { Decomposition } \\
\text { Spring } 08 \\
\left(g^{-1}\right)\end{array}$ & $\begin{array}{c}\text { Decomposition } \\
\text { Summer } 08 \\
\left(g^{-1}\right)\end{array}$ & $\begin{array}{c}\text { Processing } \\
\text { ability Fall } \\
07\end{array}$ & $\begin{array}{l}\text { Processing } \\
\text { ability } \\
\text { Spring } 08\end{array}$ & $\begin{array}{l}\text { Processing } \\
\text { ability } \\
\text { Summer } \\
08 \\
\end{array}$ & $\begin{array}{c}\text { Average } \\
\text { Processing } \\
\text { ability }\end{array}$ \\
\hline $\mathrm{C} 1$ & 0.0033 & 0.0038 & 0.0028 & 0.0063 & 0.00004 & 0.00001 & 0.00011 & 0.00005 \\
\hline $\mathrm{C} 2$ & 0.0041 & 0.0048 & 0.0030 & 0.0044 & 0.00008 & 0.00005 & 0.00058 & 0.00024 \\
\hline $\mathrm{C} 3$ & 0.0031 & 0.0018 & 0.0039 & 0.0037 & 0.00003 & $3.00 \mathrm{E}-06$ & 0.00017 & 0.00007 \\
\hline $\mathrm{C} 4$ & 0.0039 & 0.0013 & 0.0028 & 0.0075 & 0.00011 & 0.00010 & 0.00066 & 0.00029 \\
\hline VF1 & 0.0044 & 0.0043 & 0.0028 & 0.0061 & 0.00129 & $4.00 \mathrm{E}-06$ & 0.00009 & 0.00046 \\
\hline VF2 & 0.0057 & 0.0033 & 0.0034 & 0.0105 & 0.00040 & 0.00018 & 0.00068 & 0.00042 \\
\hline VF3 & 0.0040 & 0.0040 & 0.0042 & 0.0037 & 0.00061 & 0.00008 & 0.00019 & 0.00029 \\
\hline VF4 & 0.0043 & 0.0043 & 0.0031 & 0.0054 & 0.00026 & 0.00009 & 0.00063 & 0.00033 \\
\hline
\end{tabular}


Table 8: Results from t-tests between valley fill and control sites. The only variable that was significantly different between valley fill and control sites was processing ability in Fall 2007.

\begin{tabular}{lll}
\hline Variable & p-value & DF \\
\hline Maximum Daily CV of Temperature & 0.8685 & 7 \\
Mean Daily CV of Temperature & 0.3429 & 7 \\
Maximum Daily Temperature Range & 0.1122 & 7 \\
Mean Daily Temperature Range & 0.9654 & 7 \\
Average Temperature & 0.9345 & 7 \\
Minimum Temperature & 0.1466 & 7 \\
Maximum Temperature & 0.8762 & 7 \\
Overall CV of Temperature & 0.4863 & 7 \\
Average Conductivity & 0.4588 & 7 \\
Overall Decomposition & 0.8063 & 7 \\
Decomposition Fall 07 & 0.2674 & 7 \\
Decomposition Spring 08 & 0.5545 & 7 \\
Decomposition Summer 08 & 0.5944 & 7 \\
CV Water Level & 0.9225 & 7 \\
Average Depth (m) & 0.5279 & 7 \\
Processing ability Fall 07 & $\mathbf{0 . 0 4 6 1}$ & $\mathbf{7}$ \\
Processing ability Spring 08 & 0.3012 & 7 \\
Processing ability Summer 08 & 0.9330 & 7 \\
\hline
\end{tabular}


Table 9: Water quality values for each site. Temperature and water level were measured every 10 minutes throughout the study period. Although not significant, control sites tended to have higher CV water level than valley fill sites. VF 1 was removed from statistical analysis because the site was placed above the valley fill's sediment pond rather than below it as at all other valley fill sites. The valley fill at VF 1 was also approximately 20 years old and all other valley fills were approximately 10 years old.

\begin{tabular}{lcccccc}
\hline Site & $\begin{array}{c}\text { Conductivity } \\
(\mu \mathrm{S} / \mathrm{cm})\end{array}$ & $\begin{array}{c}\text { Average } \\
\text { Temperature } \\
\left({ }^{\circ} \mathrm{C}\right)\end{array}$ & $\begin{array}{c}\text { Average } \\
\text { Minimum } \\
\text { Temperature } \\
\left({ }^{\circ} \mathrm{C}\right)\end{array}$ & $\begin{array}{c}\text { Average } \\
\text { Maximum } \\
\text { Temperature } \\
\left({ }^{\circ} \mathrm{C}\right)\end{array}$ & $\begin{array}{c}\text { CV Water } \\
\text { Level }\end{array}$ & $\begin{array}{c}\text { Average } \\
\text { Water } \\
\text { Level }\end{array}$ \\
\hline $\mathrm{C} 1$ & 60 & 14.72 & 0.78 & 23.87 & 287.46 & 0.17 \\
$\mathrm{C} 2$ & 71 & 10.74 & 0.01 & 27.17 & 63.07 & 0.23 \\
$\mathrm{C} 3$ & 748 & 10.75 & 1.87 & 23.58 & 131.51 & 0.03 \\
$\mathrm{C} 4$ & 654 & 11.36 & 0.12 & 23.87 & 91.92 & 0.03 \\
$\mathrm{VF} 1$ & 554 & 10.77 & 4.00 & 23.20 & 456.13 & 0.01 \\
VF2 & 923 & 12.24 & 0.01 & 23.48 & 77.43 & 0.16 \\
VF3 & 602 & 10.54 & 0.01 & 25.22 & 4.90 & 0.05 \\
VF4 & 507 & 16.42 & 0.89 & 25.71 & 81.58 & 0.08 \\
\hline
\end{tabular}


Table 10: Two way ANOVA results for the effects of stream type (valley fill or control) and season on measured stream variables. Values shown are F-statistics. Stream type (valley fill or control) did not have a significant effect on any of the variables tested.

\begin{tabular}{lccc}
\hline Response & $\begin{array}{c}\text { Type } \\
\text { Effect }\end{array}$ & $\begin{array}{c}\text { Season } \\
\text { Effect }\end{array}$ & $\begin{array}{c}\text { Interaction } \\
\text { Effect }\end{array}$ \\
\hline & DF=1,18 & DF=2,18 & DF=2,18 \\
CV flow & 2.14 & 0.44 & 0.37 \\
Average depth & 1.6 & 0.51 & 0.01 \\
Average Temperature & 0.02 & $130.5^{* * *}$ & 0.81 \\
Average distance dowels & 0.001 & $7.0^{* *}$ & 0.81 \\
(meters/6 weeks) & & & \\
Average distance leaves & 0.80 & $9.0^{* *}$ & 0.52 \\
(meters/6 weeks) & & & \\
Average decomposition & 1.35 & $7.24^{* *}$ & 0.15 \\
rate & & & \\
\% Shredders & 0.72 & 1.6 & 0.27 \\
\% Collector Gatherers & 0.58 & $17.4^{* * *}$ & 0.63 \\
\% Predators & 0.18 & $6.5^{* *}$ & 0.49 \\
Conductivity & 0.91 & $5.45^{*}$ & -0.57 \\
Processing ability & 0.14 & 2.63 & 0.38 \\
\hline p p<0.05 ** p<0.01 & $* * * \mathrm{p}<0.001$ & & \\
& & & \\
\hline
\end{tabular}




\section{Expectations of sites below Valley Fills}

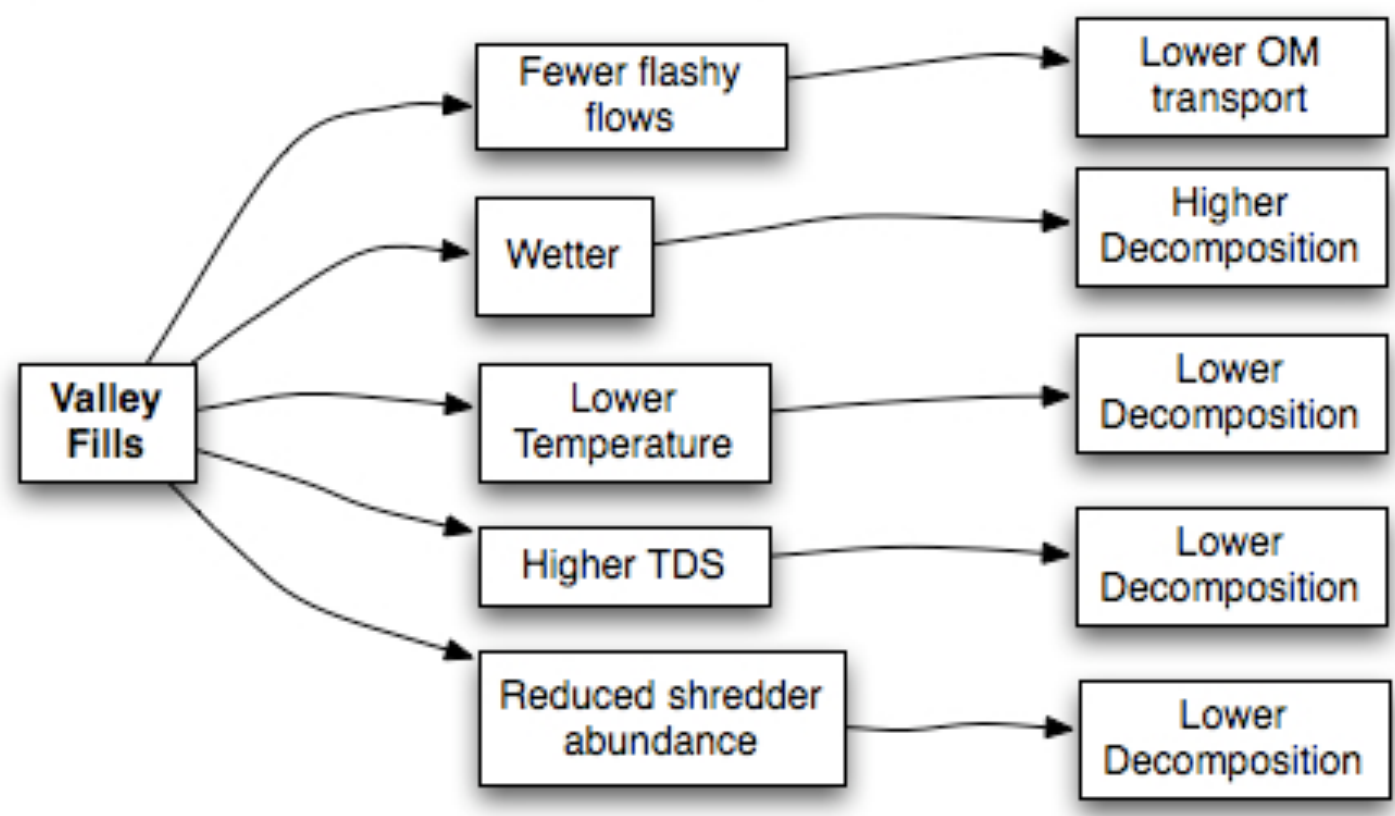

Overall: expect lowered transport and lowered decomposition in sites below valley fills

Figure 1: Expectations of how valley fills affect decomposition and organic matter transport in small headwater streams. 


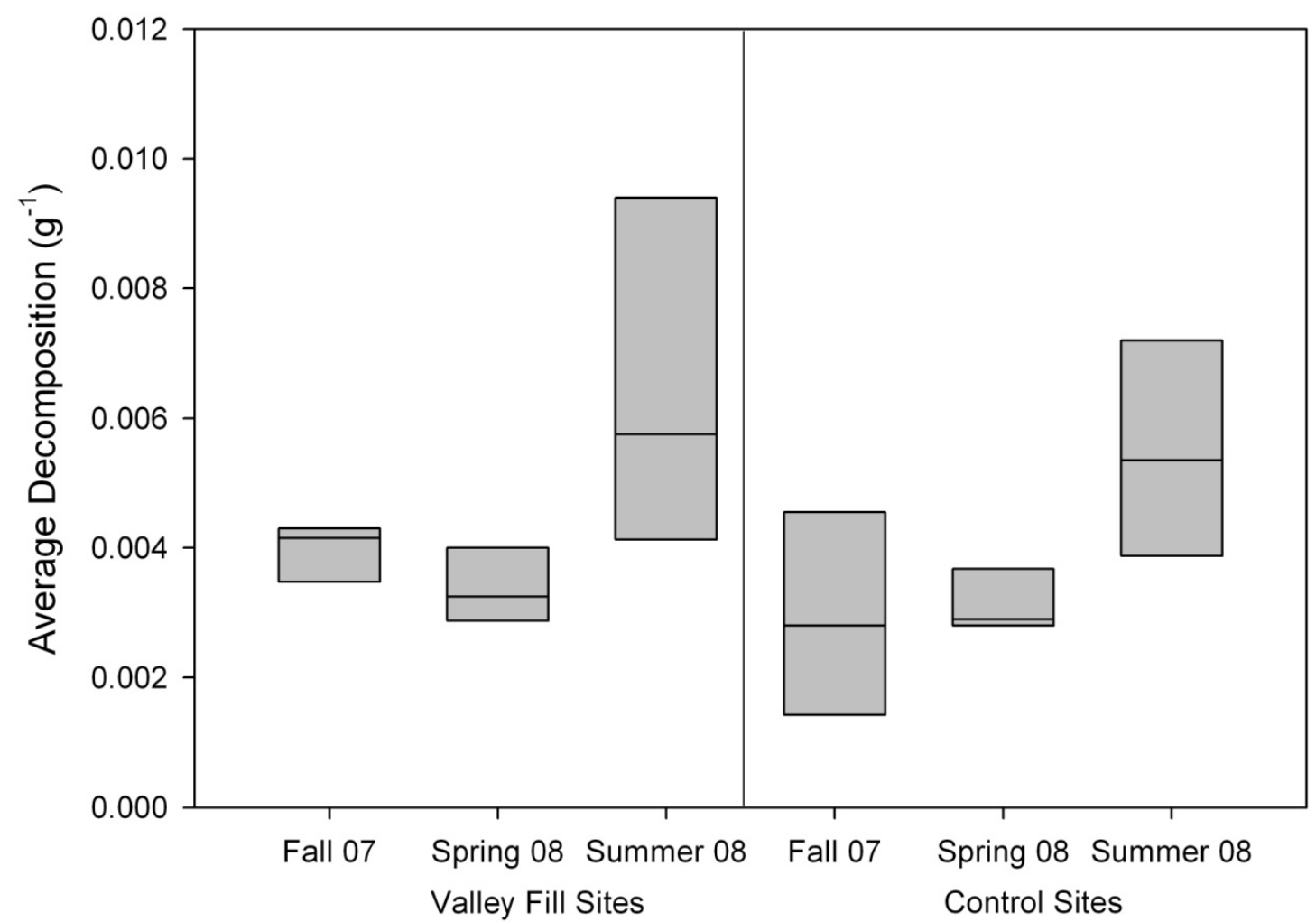

Figure 2: Range of decomposition values for valley fill and control sites separated by season. There was no significant difference in decomposition values between valley fill and control sites. 


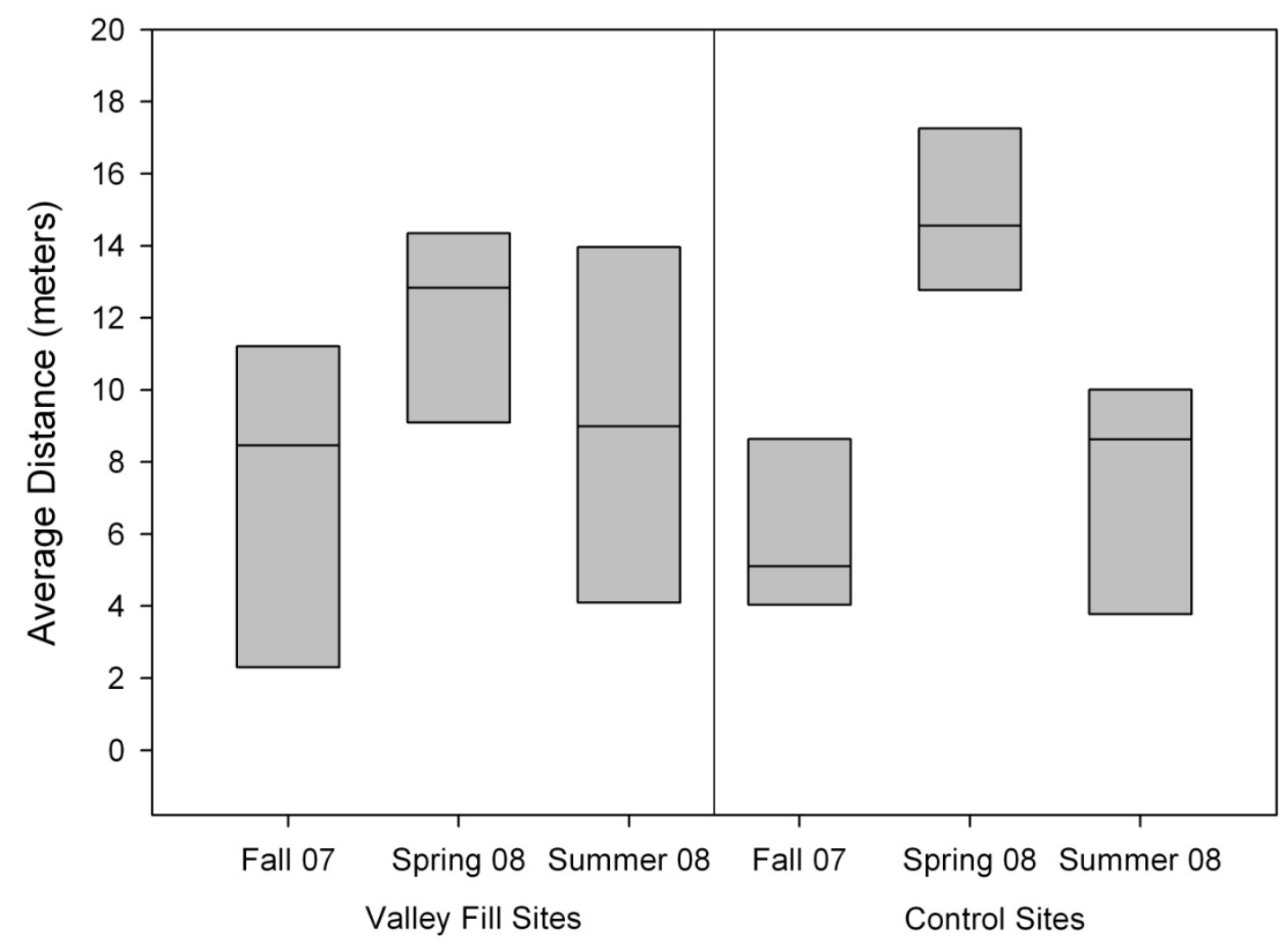

Figure 3: Average dowel transport distance for each season. There was no significant difference between valley fill and control sites. 


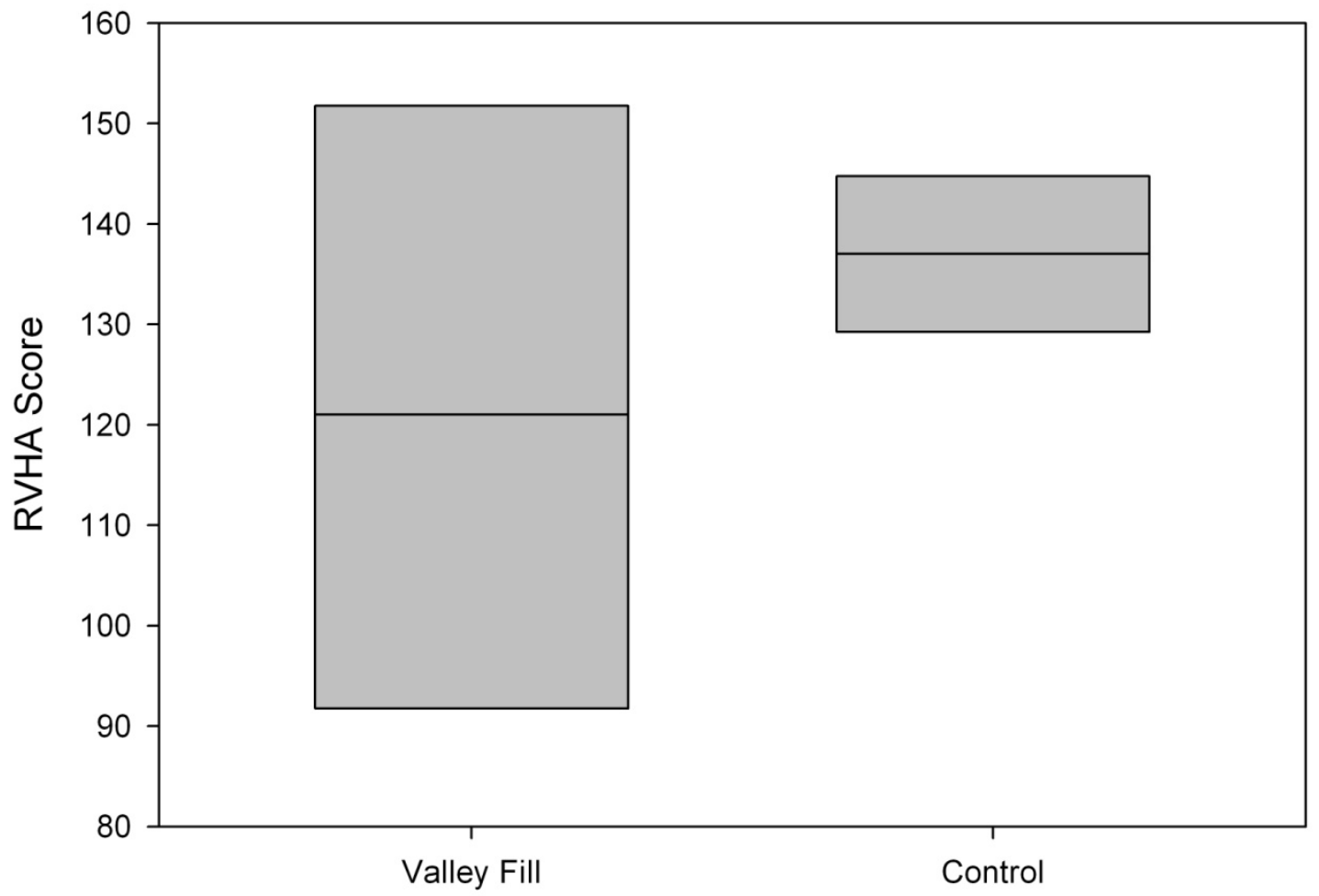

Figure 4: Rapid Visual Habitat Assessment Scores for each stream type. Valley fill sites had a wider range of habitat conditions. 


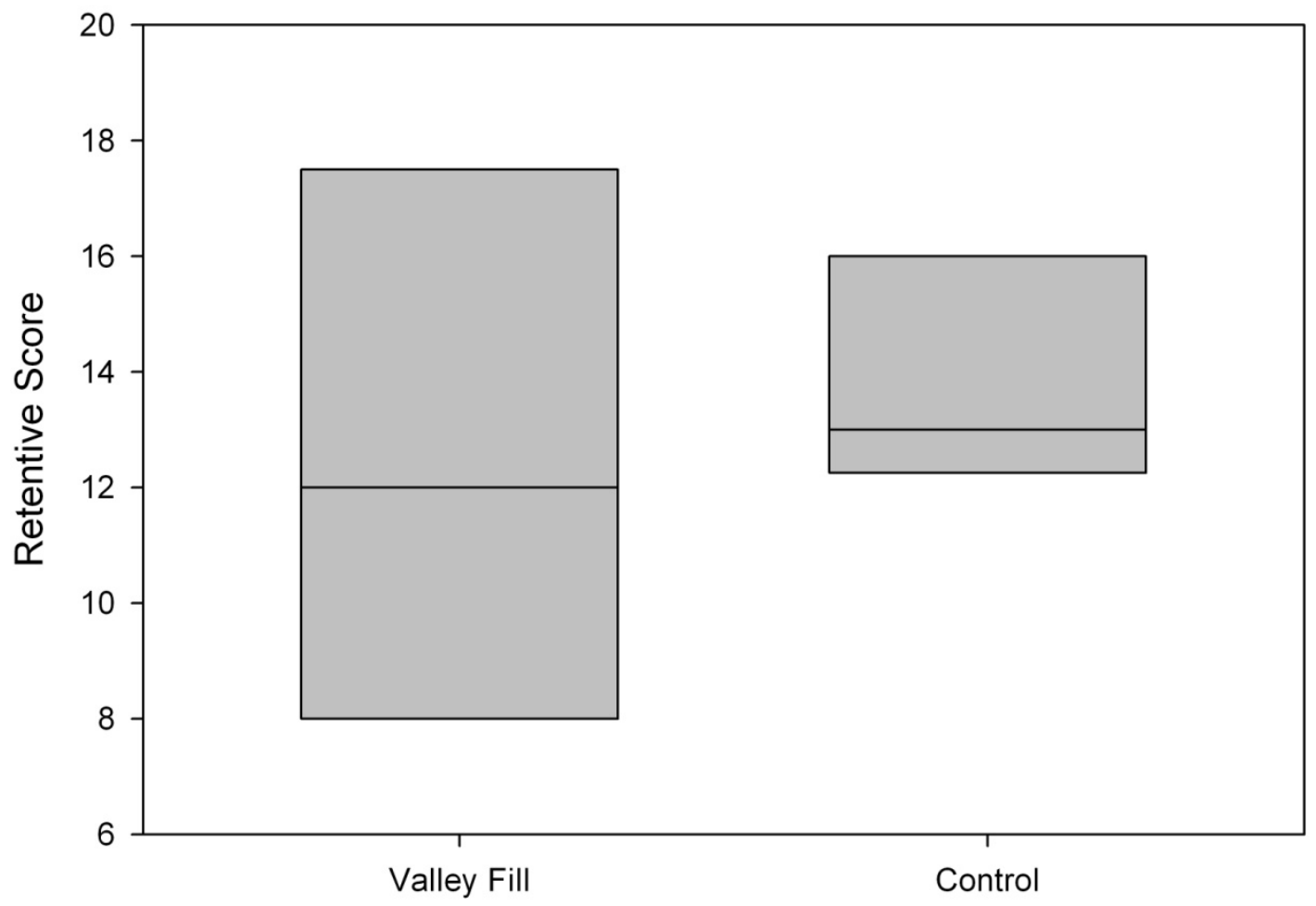

Figure 5: Range of retentive scores for control and valley fill sites. Valley fill sites had a wider range of habitat conditions. 


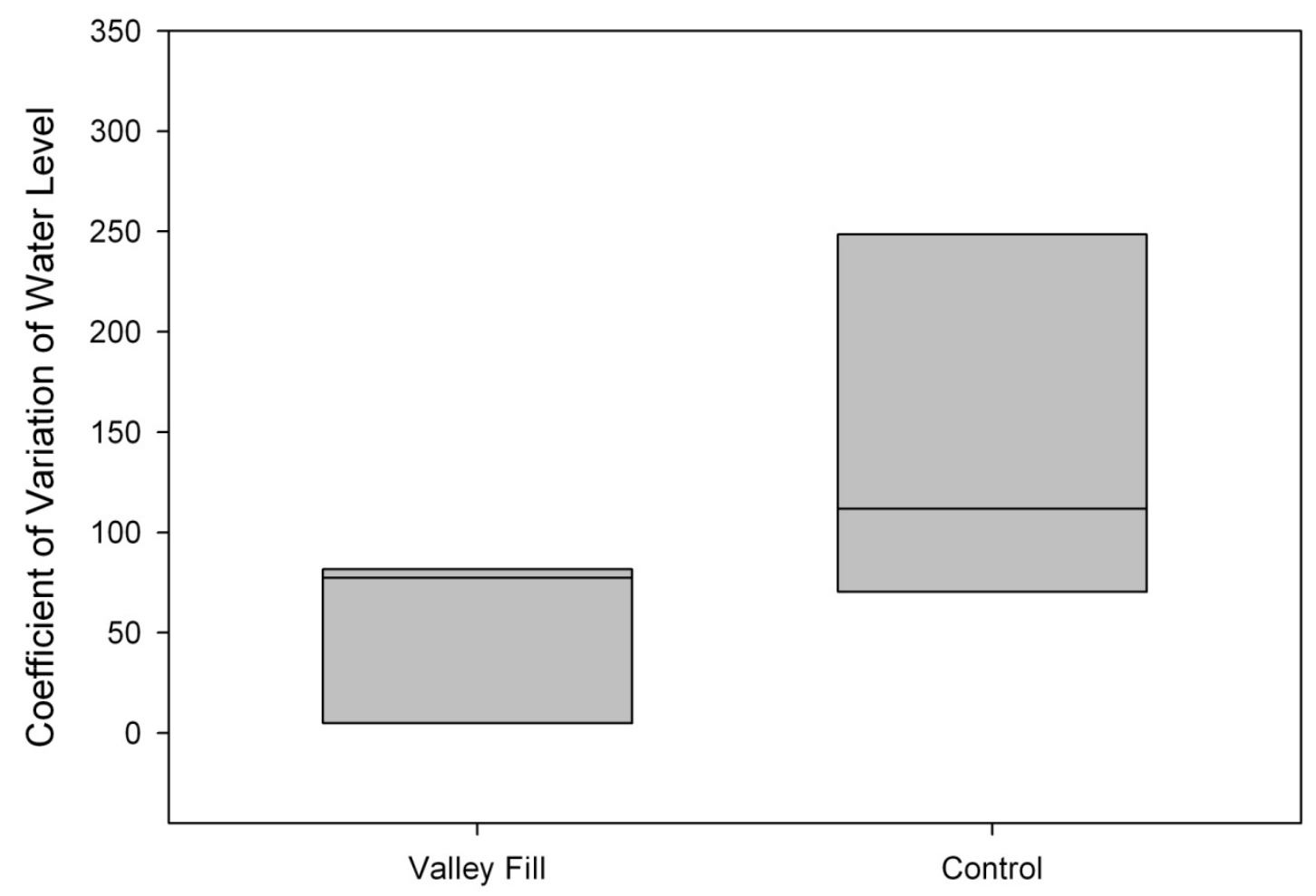

Figure 6: Range of values for the coefficient of variation of water level in control and valley fill sites. VF 1 was not included in this graph. VF 1 was removed from statistical analysis because the site was placed above the valley fill's sediment pond rather than below it as at all other valley fill sites. The valley fill at VF 1 was also approximately 20 years old and all other valley fills were approximately 10 years old. 


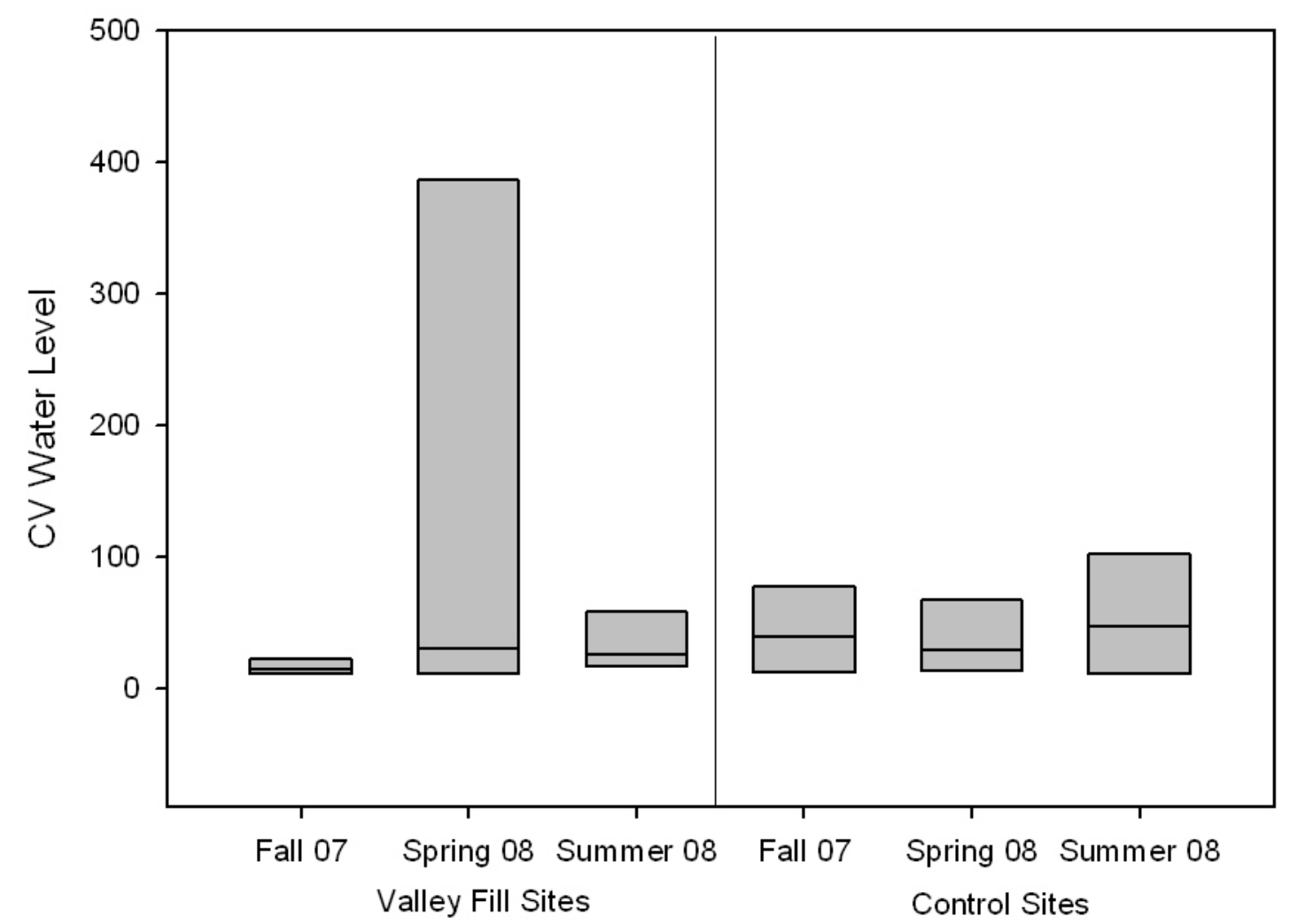

Figure 7: Seasonal CV water level without VF1. VF 1 was removed from statistical analysis because the site was placed above the valley fill's sediment pond rather than below it as at all other valley fill sites. The valley fill at VF 1 was also approximately 20 years old and all other valley fills were approximately 10 years old. 


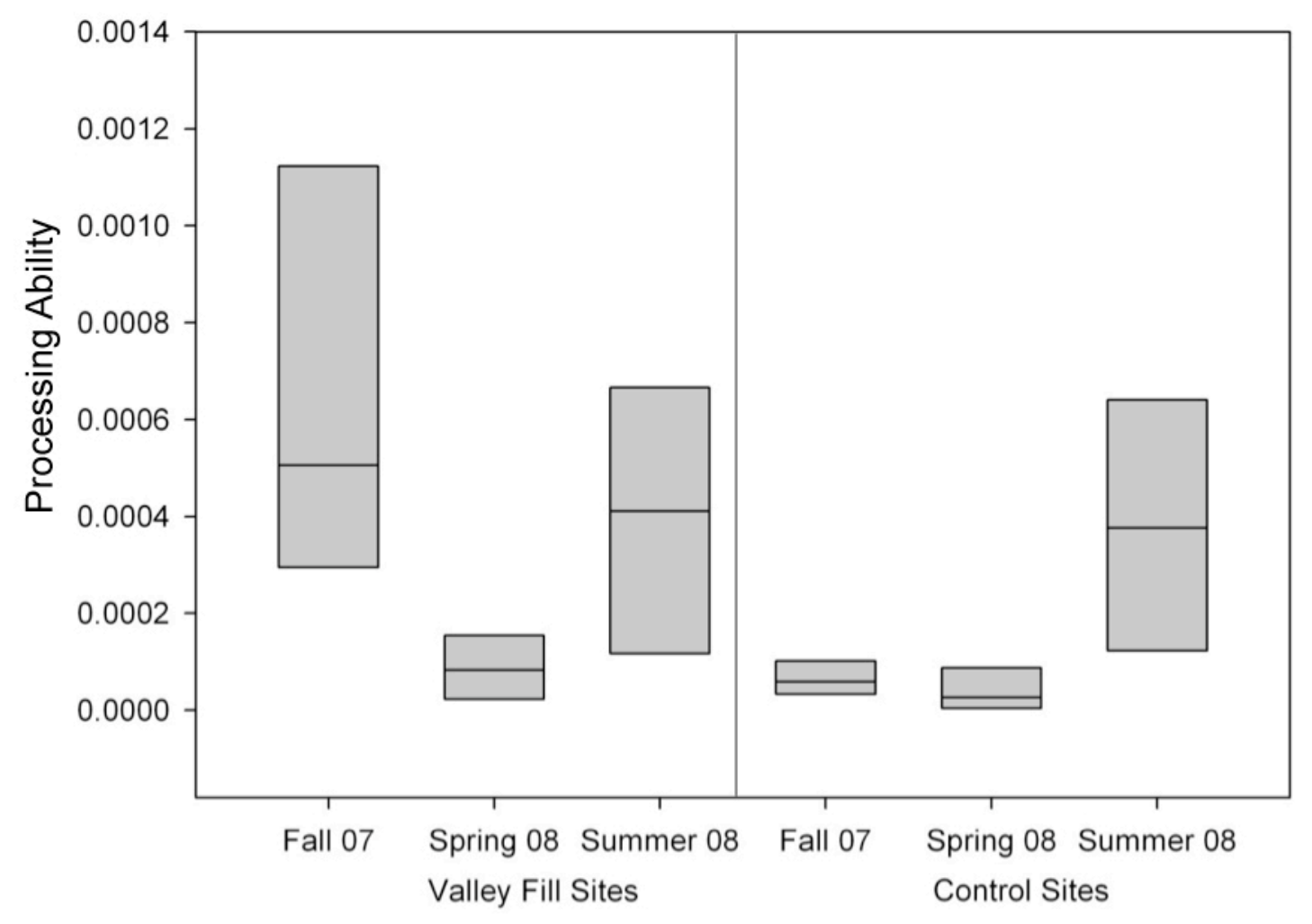

Figure 8: Seasonal processing ability for control and valley fill sites. There was no significant difference in processing ability between valley fill and control sites. 


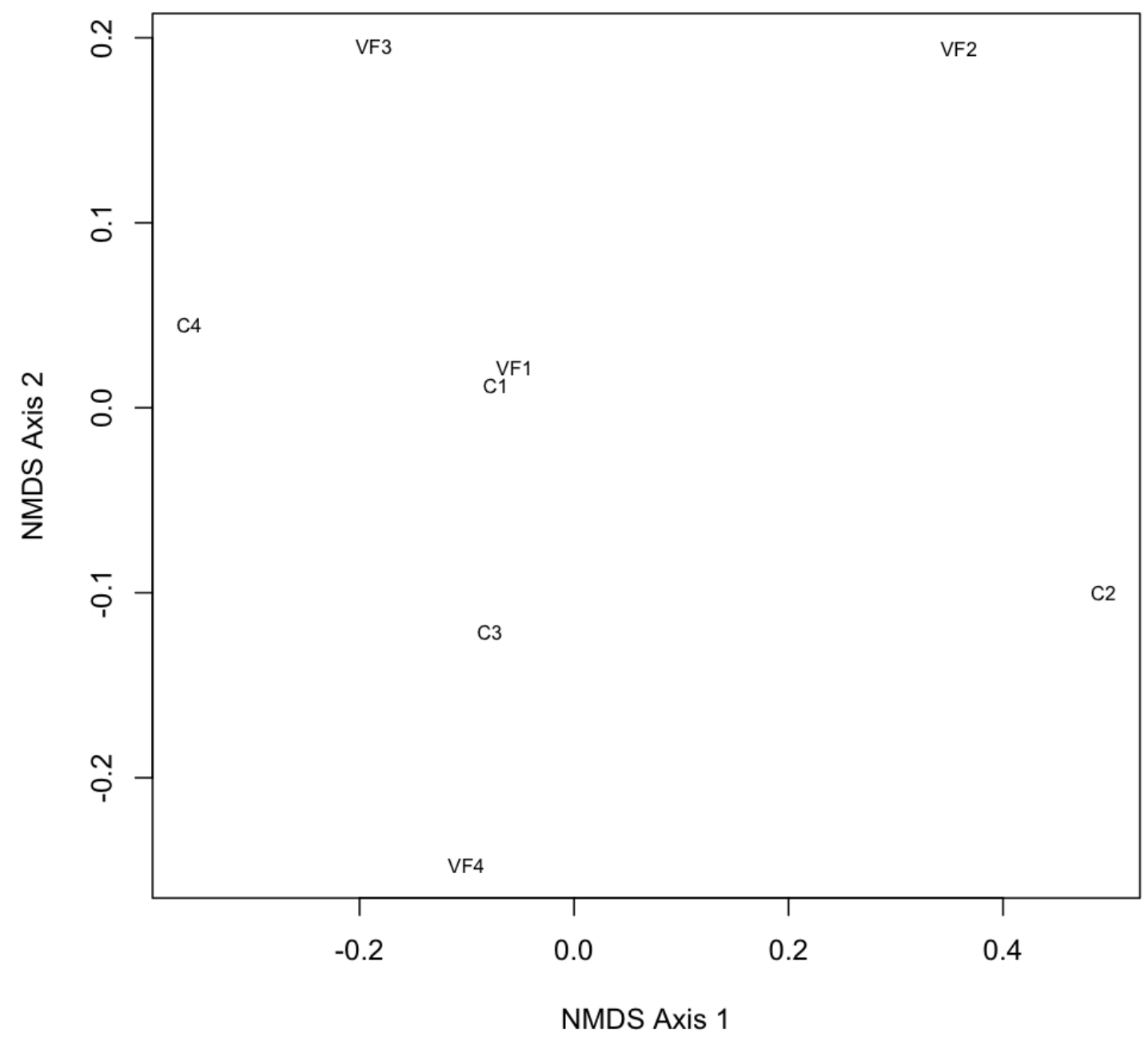

Figure 9: NMDS plot of sites in 2 dimensional space. Macroinvertebrate data was used to create this plot. Sites with similar macroinvertebrate data from leaf packs plot closer together. 


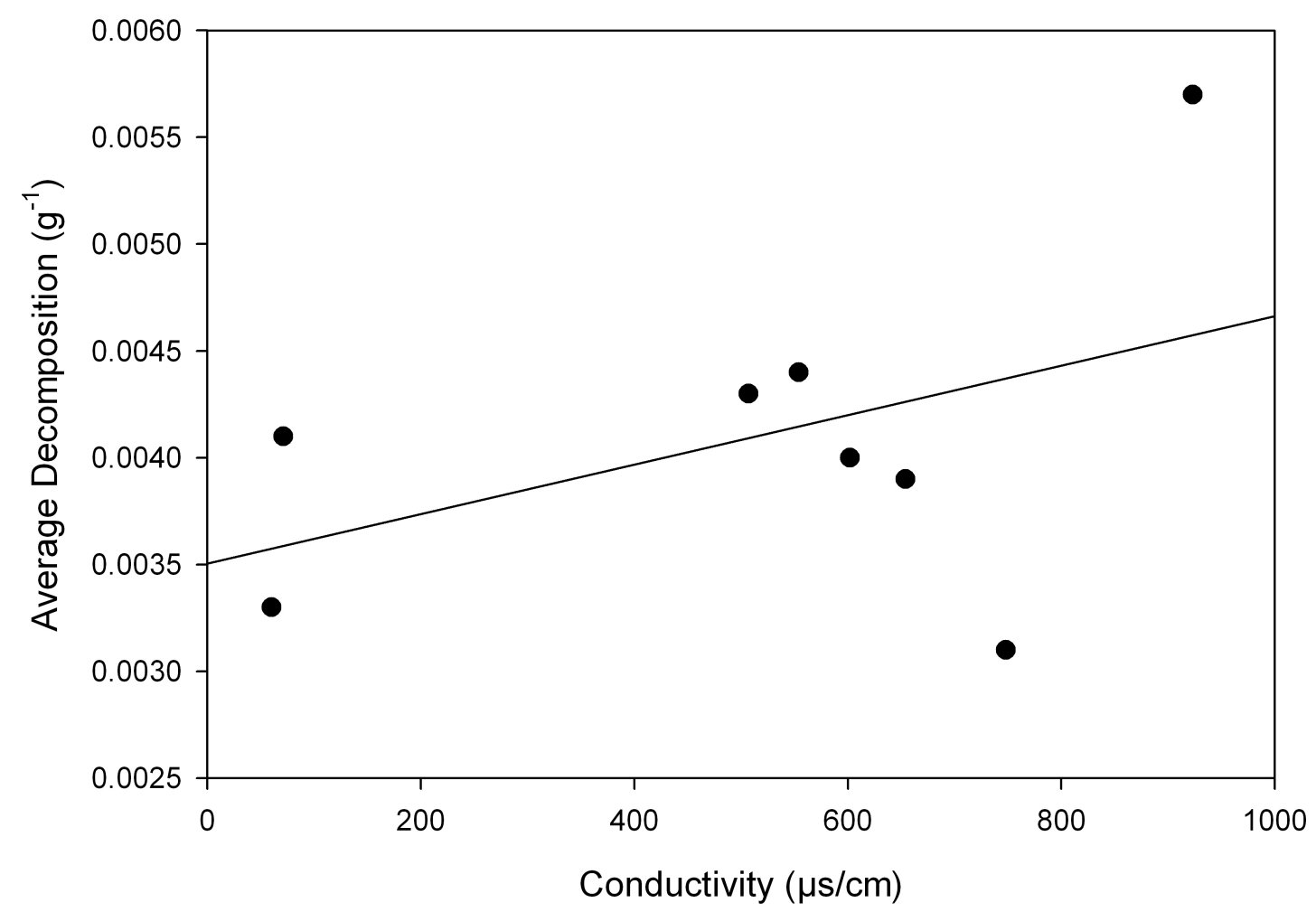

Figure 10: Average decomposition and conductivity in 4 control sites and 4 sites below valley fills. There is a slight positive relationship between decomposition and conductivity. 


\section{Appendix 1: Procedure developed and used to give each stream a retentive score}

Retentiveness is based on two separate parts: abiotic retentiveness and biotic retentiveness. The stream should be scored on how well it will retain organic matter (small sticks and leaves) after walking the entire reach. The important thing to remember is to score streams based on what would be ideal for that particular stream's basin area. For example, a small headwater stream will be inherently more retentive than a $3^{\text {rd }}$ or $4^{\text {th }}$ order stream. The larger stream shouldn't score lower than the headwater stream just based on size alone. If both streams were optimal for their size, they would both receive the same score.

Headwater streams tend to have more LWD and more boulders to catch organic matter. Also, water levels are lower so more organic matter is retained. An ideal headwater stream will have many LWD pools and riffles with rocks and boulders protruding above the water surface. Boulders, sharp bends, LWD, pools, and root wads are ideal for retaining organic matter. These features are also important in larger streams, but in a large stream, they will be more spaced out. Streams with good fish cover will usually get a high retentiveness score. Having a good velocity depth regime is important in a large stream because pools retain lots of organic matter. Also boulders that protrude above the surface, undercut banks, and LWD that spans the entire width of the channel make excellent retentive features. Retentive features in larger streams also need to be larger than ones in headwater streams because of the difference in discharge.

Retentive features fall into two categories: small retentive features and large retentive features. Small retentive features include a single piece of LWD, a side 
pool, a section of undercut bank, or a single boulder. What distinguishes large features from small ones is that large features are capable of retaining organic matter during a bankfull event. These would include debris jams, very large boulders, and groups of boulders. It is important, especially in larger channels, that large retentive features be present throughout the reach. Retentive features often can easily be seen in the Fall because leaf packs will be present on the upstream side of them.

For the purpose of this habitat assessment, a stream is scored based on its abiotic retentiveness and its biotic retentiveness. Abiotic retentive features include: boulders, undercut banks, a natural meander pattern, and side pools. Biotic retentive features include: LWD, root wads, and overhanging limbs.

\section{Category Descriptions}

\section{Abiotic Retention}

Poor Category $(0,1,2)$

- Reach is channelized, no natural meander pattern

- Lack of a riffle pool sequence; 1 velocity-depth regime, usually slow-deep or fast-deep OR stream bottom is mostly bedrock

- Boulders have been removed

- No undercut banks or side pools

- No more than 1 large retention feature in reach

Marginal Category $(3,4,5)$ 
- Extensive channelization, but not entire reach OR evidence of recent past channelization

- Stream mostly dominated by runs and glides; 2 velocity-depth regimes OR a large portion of the stream bottom is bedrock

- Few side pools with leaves on the bottom

- Few protruding boulders or bends to retain leaves

- No more than 2 large retention features in reach

Suboptimal Category $(6,7,8)$

- Channel shape mostly has a natural pattern; human activity in floodplain largely does not affect it

- Boulders can be seen protruding above the surface of the water, but they are small and spread out.

- 3 of the 4 velocity depth regimes are present and there are retention features in fast water areas. Very few areas of bedrock

- pools with leaves on the bottom are present throughout the reach, but they may frequently get flushed out

- No more than 3 large retention features in reach

Optimal Category $(9,10)$

- Channel has a natural meandering pattern

- Protruding boulders can be seen throughout the reach

- Stream has a natural velocity-depth regime

- Retention features can be readily seen in fast water 
- Over 3 large retention features in reach

- Pools with leaves on the bottom can be seen throughout the reach

- Leaves are able to be retained on banks in bends

\section{Biotic Retention}

Poor Category $(0,1,2)$

- Obvious lack of LWD and pools formed by LWD; 1 or less

- No root wads that can retain leaves

- Very few leaf packs seen in reach

- No debris jams in reach

- No overhanging vegetation capable of retaining leaves

Marginal Category $(3,4,5)$

- Few pieces of LWD, root wads, and LWD pools

- Very few debris jams and leaf packs in reach

- 1 or 2 pieces of overhanging vegetation capable of retaining leaves may be present

- Poor category will show almost no biotic retention features; marginal category will have a few features, but most have been removed

Suboptimal Category $(6,7,8)$

- LWD is present in the reach, but some pieces may small, unstable, or not span entire width of the channel

- Root wads and overhanging vegetation are present in the reach

- Leaf packs and debris jams can also be found in the reach 
Optimal Category $(9,10)$

- LWD is present throughout the reach and it forms pools and is stable

- Overhanging limbs contribute to retaining leaves and sticks

- Root wads create areas where leaves can be retained

- Debris jams and leaf packs can be found throughout the reach and some debris jams span the entire width of the stream

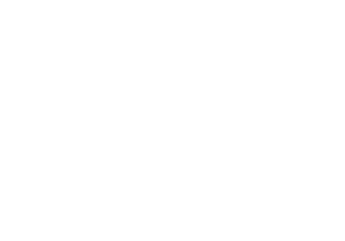

